I N T ER N ATIONAL MONETARY FUND

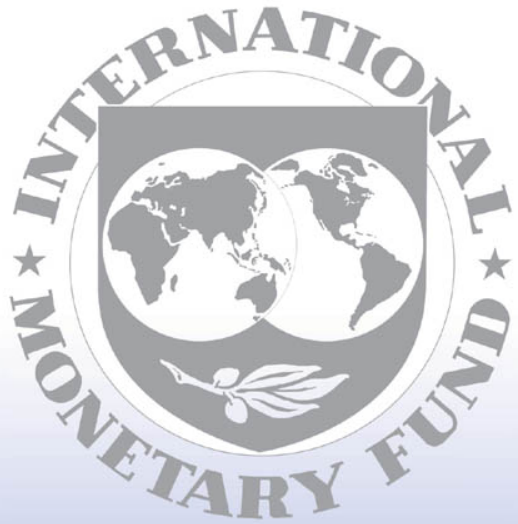

Staff

Country

Reports 
Sierra Leone: Sixth Review Under the Poverty Reduction and Growth Facility, Requests for Waiver of Performance Criteria and Additional Interim Assistance Under the Enhanced Initiative for Heavily Indebted Poor Countries, Review of Financing Assurances, and Ex Post Assessment of Longer-Term Program Engagement-Staff Report; Staff Statement; Press Release on the Executive Board Discussion; and Statement by the Executive Director for Sierra Leone

In the context of the sixth review under the Poverty Reduction and Growth Facility, requests for a waiver of performance criteria and additional interim assistance under the enhanced Initiative for Heavily Indebted Poor Countries, review of financing assurances, and ex post assessment of longerterm program engagement with Sierra Leone, the following documents have been released and are included in this package:

- the staff report for the sixth review under the Poverty Reduction and Growth Facility, requests for waiver of performance criteria and additional interim assistance under the enhanced Initiative for Heavily Indebted Poor Countries, review of financing assurances, and ex post assessment of longer-term program engagement, prepared by a staff team of the IMF, following discussions that ended on February 28, 2005, with the officials of Sierra Leone on economic developments and policies. Based on information available at the time of these discussions, the staff report was completed on May 10, 2005. The views expressed in the staff report are those of the staff team and do not necessarily reflect the views of the Executive Board of the IMF.

- $\quad$ a staff statement of June 1, 2005 updating information on recent developments.

- $\quad$ a Press Release summarizing the views of the Executive Board as expressed during its June 1, 2005 discussion of the staff report that completed the review and requests.

- $\quad$ a statement by the Executive Director for Sierra Leone.

The documents listed below have been or will be separately released.

Letter of Intent sent to the IMF by the authorities of Sierra Leone*

Memorandum of Economic and Financial Policies by the authorities of Sierra Leone*

* May also be included in Staff Report

The policy of publication of staff reports and other documents allows for the deletion of market-sensitive information.

To assist the IMF in evaluating the publication policy, reader comments are invited and may be sent by e-mail to publicationpolicy@imf.org.

Copies of this report are available to the public from

International Monetary Fund • Publication Services

$70019^{\text {th }}$ Street, N.W. • Washington, D.C. 20431

Telephone: (202) 623-7430 • Telefax: (202) 623-7201

E-mail: publications@imf.org Internet: http://www.imf.org

Price: $\$ 15.00$ a copy

International Monetary Fund

Washington, D.C. 
This page intentionally left blank

(CInternational Monetary Fund. Not for Redistribution 
INTERNATIONAL MONETARY FUND

SIERRA LEONE

\title{
Sixth Review Under the Poverty Reduction and Growth Facility Arrangement, Requests for Waiver of Performance Criteria and Additional Interim Assistance Under the Enhanced Initiative for Heavily Indebted Poor Countries, Review of Financing Assurances, and Ex Post Assessment of Longer-Term Program Engagement
}

\author{
Prepared by the African Department \\ (In consultation with the Finance, Fiscal Affairs, Legal, Monetary and Financial Systems, \\ Policy Development and Review, and Statistics Departments)
}

Approved by Siddharth Tiwari and Carlo Cottarelli

May 10, 2005

- A mission visited Freetown during February 15-28, 2005, to conduct the sixth (and final) review of the PRGF arrangement and to discuss the assessment of Fund's long-term program engagement with Sierra Leone. The team consisted of Messrs. Rwegasira (head), Kovanen, and Köhler (all AFR), Mr. Elekdag (PDR), and Ms. Smith (staff assistant, AFR). Mr. Arora (AFR), the head of the ex post assessment (EPA) team, visited Freetown during February 22-25 for discussions on the EPA report. The staff met with His Excellency, President Kabbah, the Minister of Finance, the Governor of the Bank of Sierra Leone, other senior government officials, and representatives of the donor community.

- The authorities are requesting a waiver for the nonobservance of a quantitative performance criterion and a structural performance criterion. They have also expressed interest in continued Fund support through a successor PRGF arrangement. To help maintain the momentum in economic policy implementation until a possible successor program is in place, the staff reached understandings with Sierra Leonean authorities on the macroeconomic framework for 2005.

- On September 26, 2001, the Executive Board approved a three-year PRGF arrangement with Sierra Leone in the amount of SDR 130.84 million (126 percent of quota). In the context of the fourth review under the PRGF arrangement, the Executive Board extended the PRGF arrangement for six months to expire on March 25, 2005.

- The 2004 Article IV consultation and the fifth review under the PRGF arrangement were completed on November 12, 2004, Country Report No. 05/23. On that occasion, Executive Directors emphasized that the authorities needed to better prioritize expenditures in the context of poverty reduction efforts and to coordinate with donors to ensure more efficient fiscal management and the mobilization of increased resources for poverty reduction programs. Directors also encouraged the authorities to clearly articulate the policy agenda that would emerge from the PRSP exercise, as this would help in securing donor support. The Executive Board also extended the PRGF arrangement for another three months until June 25, 2005.

- Upon completion of the sixth review, Sierra Leone would be eligible to draw SDR 14 million (US\$21 million). 


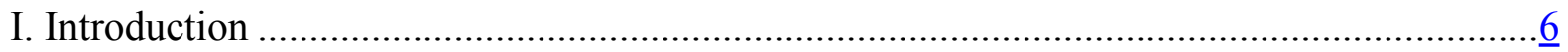

II. Recent Developments and Performance Under the Program..............................................

A. Recent Political and Economic Developments .......................................................

B. Performance Under the Program at end-December 2004 .....................................11

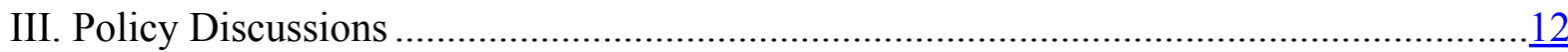

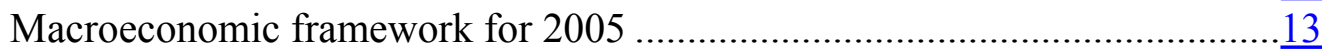

Fiscal policy ..........................................................................................14

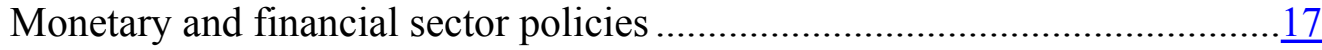

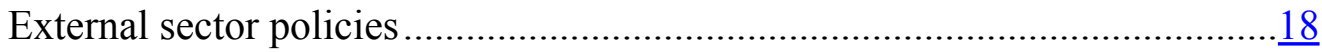

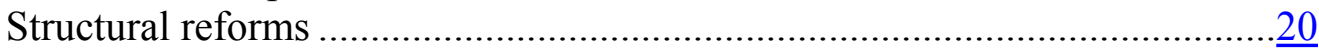

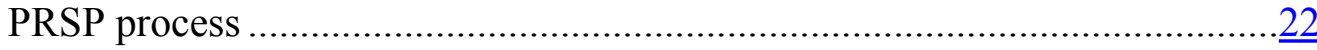

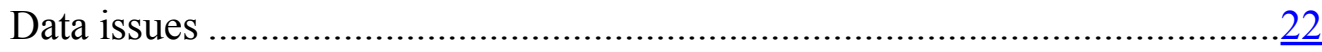

The ex post assessment ................................................................................

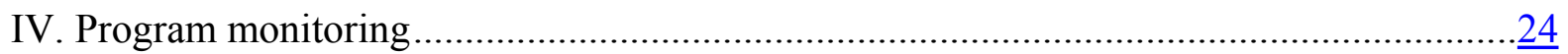

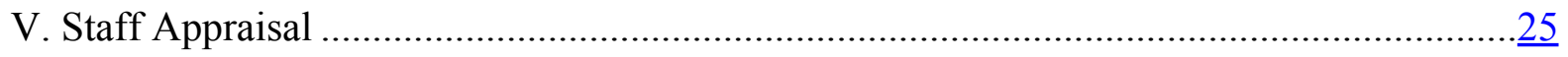

Tables

1. Selected Economic and Financial Indicators, 2001-07 ……………………………..... $\frac{30}{31}$

2. Central Government Financial Operations, 2001-05 ...................................................

3. Monetary Survey, December 2001-December 2005 ………………………………..... $\frac{33}{34}$

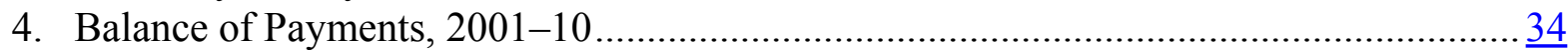

5. Poverty-Related Expenditure by Activity, 2001-05 .................................................. $\frac{35}{36}$

6. External Financing Requirements and Sources, 2002-10 ............................................

7. Indicators of Capacity to Repay the Fund, 2001-10 ..................................................

8. Disbursements Under the PRGF Arrangement, 2001-05 .............................................

9. Status of HIPC Initiative Completion Point Triggers (Status as of February 2005) …...... $\underline{39}$

10. Selected Social and Demographic Indicators ............................................................. 41

Figures

1. Inflation and Money Growth, January 2004-February $2005 \ldots \ldots \ldots \ldots \ldots \ldots \ldots \ldots \ldots \ldots \ldots \ldots \ldots \ldots \ldots . .28$

2. Nominal and Real Effective Exchange Rates, January 2000-December 2004 ................ 29

Boxes

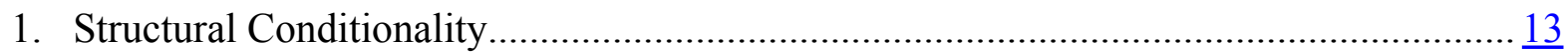

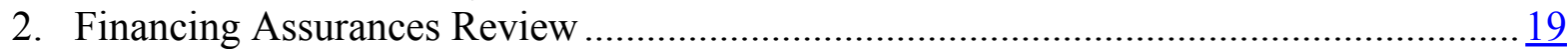

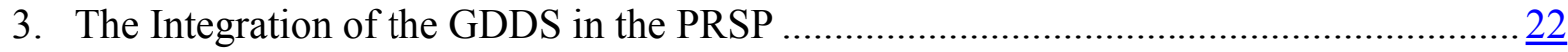


Appendices

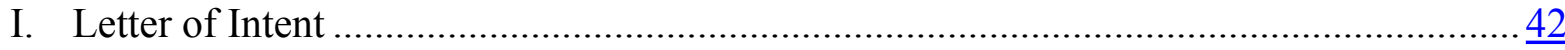

II. Relations with the Fund .....................................................................................

III. Relations with the World Bank Group .................................................................... $\frac{51}{53}$

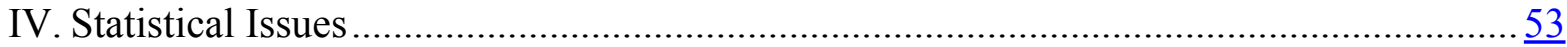

V. A Tentative Work Program.....................................................................................

Appendix Tables

1. Quantitative Performance Criteria and Indicative Targets ............................................. 44

2. Prior Actions and Structural Benchmarks Subject to the Sixth Review............................ 45

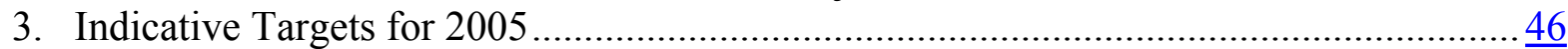




\section{EXECUTIVE SUMMARY}

- Broad-based economic recovery continued in 2004. The output expansion of $71 / 2$ percent reflected robust activity in key sectors. However, inflation rose steadily for most of the year, peaking at 15 percent, but a fiscal tightening and a slowdown in money growth in the fourth quarter contributed to some deceleration to $14 \frac{1}{2}$ percent by year-end; this downward trend continued, reaching 71/2 percent in February 2005. The external current account improved significantly in 2004, helped by stronger-thanenvisioned exports and lower imports.

- Performance under the program at end-2004 was mixed. The authorities have, however, taken steps to address the shortcomings. The 2005 budget represents the authorities' continued effort toward medium-term fiscal sustainability. The unforeseen wage-related demands in January 2005 are to be offset through additional revenue efforts and reductions in nonwage outlays. The staff has urged the authorities to contain these demands. The authorities have also made further progress in implementing structural reforms, in part to strengthen policy implementation in the run-up to the sixth review under the PRGF arrangement.

- While output growth is projected to remain strong in 2005 and beyond, significant uncertainty relates to inflation. Fiscal policy will be key to supporting macroeconomic stability. The overall fiscal deficit (including grants) is projected at 4.6 percent of GDP, which is higher than in 2004, owing to higher externally financed project expenditures. The primary deficit is expected to decline significantly. Monetary policy needs to be more proactive, and the central bank should be vigilant in ensuring that commercial banks remain sound and well capitalized.

- Sustained high growth will require continued structural reforms. The outstanding elements of the current public sector oriented reform agenda will need to be finalized. The staff and donors deem that most of these reforms will realistically require a longer period to implement. Furthermore, as public sector management strengthens, a shift in the balance of reforms in favor of the private sector would promote muchneeded private investment. In this regard, an aggressive privatization agenda would assist in raising revenue as well as enhancing efficiency.

- Sierra Leone has completed a full poverty reduction strategy paper (PRSP), which will provide a coherent framework for the authorities to pursue medium-term poverty-reduction objectives and the Millennium Development Goals (MDGs). The Fund and the World Bank have issued a Joint Staff Advisory Note (JSAN). ${ }^{1}$ A Consultative Group meeting is scheduled for early June 2005 in Paris during which

\footnotetext{
${ }^{1}$ See www.imf.org.
} 
the government plans to seek financing for the PRSP activities, including the filling of the financing gap in poverty-related spending in 2005 and 2006.

- The authorities broadly concurred with the conclusions of the EPA of the Fund's longer-term engagement with Sierra Leone. They strongly supported an early move to a successor arrangement, given that Sierra Leone has not reached the HIPC Initiative completion point and that a Fund-supported arrangement would play a catalytic role in mobilizing external assistance. 


\section{INTRODUCTION}

1. This report reviews developments during 2004 in the context of the sixth and final program review under Sierra Leone's Poverty Reduction and Growth Facility (PRGF) arrangement with the Fund. It also discusses the macroeconomic framework and policies for 2005. In addition, the report summarizes the discussions with the Sierra Leonean authorities on the EPA of longer-term program engagement with the Fund. ${ }^{2}$

2. The authorities have implemented an economic reform program supported by a PRGF arrangement since 2001. In the attached letter of intent (LOI; Appendix I), the authorities summarize the country's performance in the context of the final program review and request a waiver for the nonobservance of one quantitative and one structural performance criterion. They also express interest in continued Fund support through a successor PRGF arrangement.

\section{The authorities also request a further extension of interim HIPC Initiative} assistance to Sierra Leone because of the exceptional circumstances of the country's highly vulnerable external position and the need to help smooth out the profile of debt service payments to the Fund. Sierra Leone reached the decision point under the HIPC Initiative in March 2002, but completed a full PRSP only in February 2005. The implementation of the PRSP is set to start in mid-2005, and, therefore, Sierra Leone could reach the HIPC Completion Point in mid-2006 at the earliest. The current interim HIPC Initiative assistance expired on March 20, 2005. Sierra Leone's external balance of payment position remains fragile. Identified support from donors is projected to fall from US\$143 million in 2004 to US\$94 million in 2005. External reserves remain low, in comparison to Sierra Leone's vulnerability to external shocks, and the reserves are projected to decline to 2.8 months of imports by end-2005. The country's post-conflict situation also underscores the critical importance of adequate external support. Without additional interim HIPC Initiative assistance in 2005, Sierra Leone's principal repayments to the Fund would rise significantly relative to the three previous years. Hence, the Sierra Leonean authorities are requesting a further extension of interim assistance in an amount equivalent to SDR 4 million for the period up to December 2005, as it would help smooth out principal repayment obligations falling due to the Fund. This would bring total interim HIPC Initiative assistance to 67 percent of the assistance committed. ${ }^{3}$

\footnotetext{
2 Www.imf.org

${ }^{3}$ This is categorized under exceptional circumstances, bringing the assistance level above the normal cumulative limit of 60 percent of the total committed in accordance with Section III, paragraph 3(d) of the PRGF-HIPC Trust Instrument.
} 


\section{Recent Developments and Performance Under the Program}

\section{A. Recent Political and Economic Developments}

4. Sierra Leone made further progress in 2004 toward completing the post-conflict transition and successfully held local government elections. The mandate of the United Nations peacekeeping mission for Sierra Leone, UNAMSIL, has been extended to December 2005 to allow more time for the government to train military and police forces. As part of the phased withdrawal, UNAMSIL forces handed over the responsibility for the security for the capital city Freetown to Sierra Leonean police and security forces in October. Improved security in neighboring Liberia will also contribute positively to the stability of Sierra Leone. Local government elections in May 2004 represented an important step in the government's strategy to empower the local governments and to provide key public sector services in social and economic sectors through them.

5. Broad-based economic recovery continued in 2004 (Table 1). Output is estimated to have grown at $7 \frac{1}{2}$ percent in 2004 , reflecting robust activity in agriculture, diamond mining, manufacturing, and services. However, inflation remained high, peaking at 15 percent in August (Figure 1). It was fuelled by expansionary policies during the first half of the year and by higher costs for imported fuel. It also reflected an exchange rate passthrough and temporary supply constraints on domestic staple foods. Partly owing to policy tightening toward year-end, inflation declined during the subsequent months and reached $71 \frac{1}{2}$ percent in February 2005.

Sierra Leone: Growth and Inflation, 2001-04

\begin{tabular}{lrrrrrr}
\hline & 2001 & 2002 & 2003 & \multicolumn{2}{c}{2004} \\
\cline { 5 - 7 } \cline { 5 - 7 } & Act. & \multicolumn{1}{c}{ Est. } & \multicolumn{1}{c}{ Est. } & Prog. & Est. \\
\hline & 18.2 & 27.5 & 9.3 & 7.4 & 7.4 \\
Real GDP & 1.8 & -3.6 & 8.2 & 14.4 & 16.0 \\
GDP deflator & 3.4 & -3.1 & 11.3 & 12.8 & 14.4 \\
Consumer prices (end of period) & 2.6 & -3.7 & 7.5 & 12.4 & 14.2 \\
Consumer prices (annual average) & &
\end{tabular}

Sources: Sierra Leonean authorities; and IMF staff estimates.

6. Fiscal performance in $\mathbf{2 0 0 4}$ was stronger than programmed, after a successful tightening in the second half of the year (Table 2). Domestic revenue collection of 12.3 percent of GDP exceeded the program target for the year as a whole. However, although the government contained goods and services expenditures during the second half of the year, recurrent expenditures for the year as a whole were higher than programmed as a result of larger-than-programmed wages and salaries, goods and services outlays, and domestic interest payments. Poverty-related expenditures fell short of the programmed target, in part because of a slowdown in disbursements following the introduction of new procurement procedures in 2004, while the fiscal tightening in the second half of the year also cut into poverty-related outlays. The overall fiscal deficit was smaller than programmed because externally financed development expenditures were lower than envisioned. The domestic 
primary deficit exceeded the program target by a very small margin (less than 0.1 percent of GDP). Financing of the budget benefited from EU and World Bank program support during the last quarter of 2004, and, consequently, domestic financing of the budget at year-end was significantly reduced.

Sierra Leone: Fiscal Performance, 2001-04

\begin{tabular}{lrrrrr}
\hline & 2001 & 2002 & 2003 & \multicolumn{2}{c}{2004} \\
\cline { 5 - 7 } & Act. & Act. & Act. & Prog. & Act. \\
\hline & \multicolumn{6}{c}{ (In } & percent of GDP) \\
Government domestic revenue & 13.0 & 12.1 & 12.4 & 12.0 & 12.3 \\
Total expenditure and net lending & 29.5 & 28.6 & 26.9 & 28.4 & 24.8 \\
$\quad$ Of which : recurrent expenditure & 24.8 & 24.2 & 22.1 & 19.6 & 20.2 \\
Overall fiscal balance & & & & & \\
$\quad$ commitment basis, including grants) & -10.6 & -8.3 & -6.7 & -7.4 & -3.5 \\
$\quad$ commitment basis, excluding grants) & -16.5 & -16.5 & -14.5 & -16.4 & -12.5 \\
Domestic primary fiscal balance & -7.7 & -7.0 & -5.6 & -2.8 & -2.8 \\
Program grants and loans & 6.8 & 6.7 & 3.3 & 5.9 & 6.9 \\
Project grants and loans & 5.1 & 4.9 & 3.9 & 8.2 & 4.1 \\
Domestic financing & 3.2 & 0.9 & 4.3 & 1.5 & -0.1 \\
\hline
\end{tabular}

Sources: Sierra Leonean authorities; and IMF staff estimates.

7. The Bank of Sierra Leone (BSL) tightened its policy stance in 2004 (Table 3). While reserve money growth at 13 percent exceeded the program target, money growth slowed notably during the second half of the year. The BSL's net foreign assets expanded significantly in the last quarter, reflecting donor disbursements. However, its net domestic assets declined because of lower borrowing by the government. Furthermore, the BSL intensified open market operations in the primary treasury bill market by selling newly issued government securities, which pushed treasury bill yields higher, and, in December, raised commercial bank statutory reserve and liquidity requirements. Broad money growth, at 19 percent, was lower than a year earlier. 
Sierra Leone: Financial Sector Indicators, 2001-04

\begin{tabular}{lrrrrr}
\hline & 2001 & 2002 & 2003 & \multicolumn{2}{c}{2004} \\
\cline { 5 - 7 } & Act. & \multicolumn{1}{c}{ Act. } & \multicolumn{1}{c}{ Act. } & Prog. & Act. \\
\hline & & \multicolumn{1}{c}{ (Annual percentage change) } \\
Broad money & 33.7 & 30.1 & 26.2 & 13.8 & 18.9 \\
Domestic credit & 6.9 & 3.0 & 12.1 & 6.9 & -1.1 \\
Government & 6.2 & 0.1 & 7.7 & 3.0 & -6.5 \\
Private sector & 24.6 & 62.3 & 64.5 & 42.0 & 45.2 \\
Reserve money & 29.4 & 24.9 & 22.4 & 6.4 & 12.6 \\
Money multiplier (end of period) & 2.0 & 2.1 & 2.2 & 2.6 & 2.3 \\
Currency to deposit ratio & 0.7 & 0.8 & 0.8 & 0.5 & 0.6 \\
$\quad$ Reserves to deposit ratio & 0.1 & 0.1 & 0.1 & 0.1 & 0.1 \\
Velocity (level) & 5.5 & 5.2 & 4.9 & 5.3 & 5.1 \\
Treasury bill interest rate (end of period; in percent) & 14.7 & 15.0 & 20.2 & 27.0 & 28.0 \\
\hline
\end{tabular}

Sources: Sierra Leonean authorities; and IMF staff estimates.

Sierra Leone: Contributions to Broad Money, 2001-05

(Annual contributions in percent)

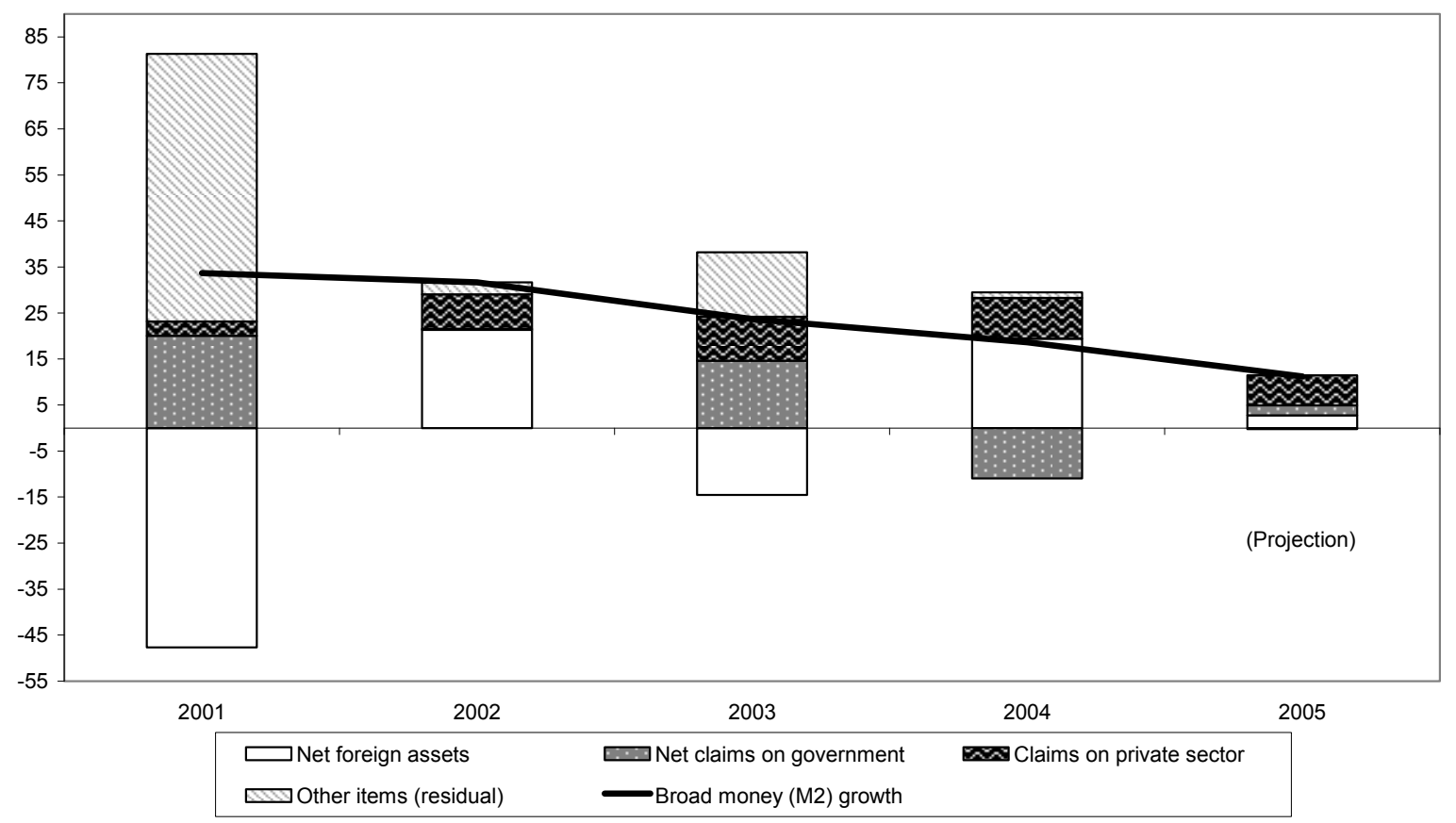

Sources: Sierra Leonean authorities; and IMF staff estimates and projections. 
8. The rapid expansion of banks' assets has eroded the quality of credit. Banking system assets expanded by 24 percent in 2004, assisted by a strong expansion of banking system deposits. Banks' risk-weighted capitalization ratios have declined as a result of rapid credit growth. ${ }^{4}$ Furthermore, the ratio of nonperforming loans to capital (net of provisioning) rose from $5 \frac{1}{2}$ percent in 2003 to $13 \frac{1}{2}$ percent in 2004 .

Sierra Leone: Financial Soundness Indicators of the Banking System, 2001-04

\begin{tabular}{|c|c|c|c|c|}
\hline & $\begin{array}{c}2001 \\
\text { Dec. }\end{array}$ & $\begin{array}{c}2002 \\
\text { Dec. }\end{array}$ & $\begin{array}{c}2003 \\
\text { Dec. }\end{array}$ & $\begin{array}{r}2004 \\
\text { Dec. }\end{array}$ \\
\hline & \multicolumn{4}{|c|}{ (In millions of leones, unless otherwise indicated) } \\
\hline Gross assets & 255,211 & 345,812 & 389,923 & 482,801 \\
\hline Gross assets (millions of U.S. dollars) & 118 & 158 & 159 & 169 \\
\hline Gross loans and advances & 37,782 & 58,645 & 103,848 & 145,249 \\
\hline \multirow[t]{2}{*}{ Deposits } & 125,602 & 174,322 & 279,365 & 351,270 \\
\hline & \multicolumn{4}{|c|}{ (In percent) } \\
\hline Assets/GDP & 15.95 & 17.59 & 16.78 & 16.68 \\
\hline Risk-weighted capital ratio & 29.40 & 48.40 & 39.79 & 38.13 \\
\hline Capital to assets & 20.00 & 18.00 & 20.26 & 12.70 \\
\hline Nonperforming loans (NPLs) to gross loans & 29.10 & 17.10 & 9.90 & 16.52 \\
\hline NPLs less provisions/net capital & -0.20 & -0.30 & 5.66 & 13.41 \\
\hline Return on assets & 11.90 & 10.40 & 10.67 & 9.90 \\
\hline Return on equity & 39.90 & 33.30 & 33.01 & 32.92 \\
\hline Net loans/deposits & 21.00 & 27.40 & 33.65 & 36.32 \\
\hline Cash assets/domestic currency deposits & 32.60 & 26.30 & 12.83 & 14.32 \\
\hline Liquid assets to deposits & 67.50 & 60.40 & 71.35 & 75.91 \\
\hline
\end{tabular}

Source: Bank of Sierra Leone.

9. There was a marked improvement in the external current account deficit in 2004 (Table 4). Although exports remained buoyant, especially of diamonds, total imports were substantially lower than envisioned despite the higher cost of fuel. The drop in imports reflected several factors: the phased withdrawal of the UNAMSIL forces from Sierra Leone and the relocation of nongovernment organizations (NGOs) to neighboring countries (especially Liberia), both of which significantly reduced the amount of duty-free imports, and the delays in restarting rutile and bauxite mining projects, which meant fewer imports of

\footnotetext{
${ }^{4}$ The ratios remain high because of the high level of government securities in banks' balance sheets.
} 
large capital items. Gross official reserves reached 3.1 months of imports at year-end and exceeded the program target by a healthy margin.

Sierra Leone: External Sector Performance, 2001-04

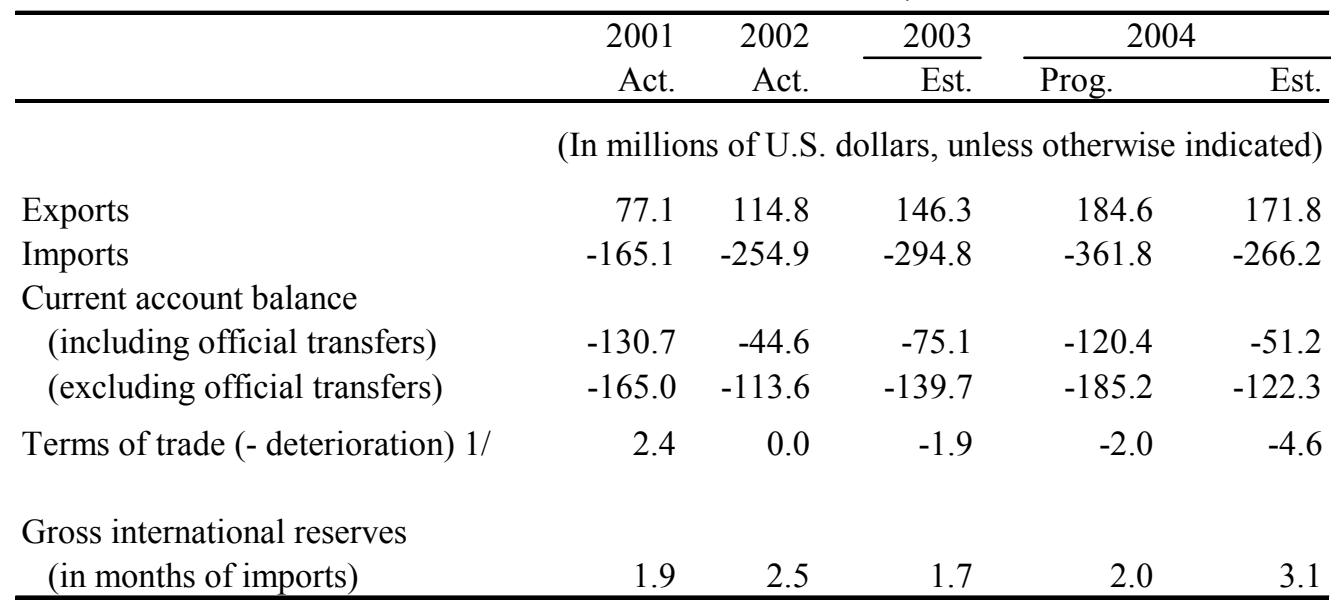

Sources: Sierra Leonean authorities; and IMF staff estimates.

$1 /$ Annual change in percent.

10. The authorities maintained a flexible exchange rate regime supported by weekly foreign exchange auctions. This has assisted external competitiveness, as suggested by a relatively small parallel market spread and a depreciation of 4 percent in the real exchange rate during 2004 (Figure 2). Furthermore, the BSL raised the amounts auctioned in the last quarter of 2004 to accommodate the increased demand for foreign exchange caused by higher fuel import costs.

\section{B. Performance Under the Program at end-December 2004}

\section{Performance under the program at end-December 2004 was mixed (Appendix I,}

Table 1). The authorities met all quantitative performance criteria except for the floor on the domestic primary budget balance which was exceeded by Le 2.7 billion (less than 0.1 percent of GDP). One reason for this was the wage bill, which remained within the program target during January-September, but increased significantly during the fourth quarter of the year owing to rising salary payments to foreign missions (because of the exchange rate depreciation) and the clearance of backlog payments to the National Social Security and Insurance Trust (NASSIT). ${ }^{5}$ The indicative target on total domestic revenue was exceeded by a comfortable margin while poverty-related outlays fell short of the program indicative target (floor), as explained earlier.

\footnotetext{
${ }^{5}$ Wages and salaries in the fourth quarter were about Le 8.7 billion ( 0.3 percent of GDP) above the program's average for a quarter.
} 
12. In respect of structural measures, a full reconciliation of fiscal and monetary data for 2000-02 (an end-November performance criterion) was not completed as originally envisioned (Appendix I, Table 2). ${ }^{6}$ Following a visit to Sierra Leone in October 2004, STA concluded that the reconciliation of fiscal and monetary data for those years would be difficult and would require substantial resources because the coverage of fiscal data as currently reported is more limited than the accounts of the government, as reflected in the monetary survey data. ${ }^{7}$ The authorities should therefore implement the new data-reporting framework recommended by STA, which would support broad-based reconciliation. In light of these considerations, the government has agreed with Fund staff to reconcile fiscal and monetary data for 2001-04 on the basis of a narrower definition of central government than originally envisioned. ${ }^{8}$ This measure is a prior action subject to the sixth review (Box 1). The new framework needs urgent implementation, as full data reconciliation has an important bearing on transparency and good governance.

\section{Three other measures have been implemented as prior actions to the sixth} review (Appendix I, Table 2). In addition, in February 2005 parliament passed the Budgeting and Accountability Act, which is expected to streamline government fiscal operations and enhance transparency. The completion of the remaining four structural benchmarks subject to this review will be postponed beyond the current program because their implementation will require a longer-time horizon than initially envisioned, and will depend to a significant degree on donor support (see also Section III).

\section{Policy Discussions}

14. In addition to reviewing performance under the PRGF arrangement as of endDecember 2004, the mission's discussions with the authorities centered on macroeconomic policies in 2005, actions required to accelerate the implementation of structural reforms and complete the sixth review under the PRGF arrangement, and the ex post assessment of Sierra Leone's long-term engagement with the Fund.

\footnotetext{
${ }^{6}$ Further discussion on structural reform measures is provided in Section III.

${ }^{7}$ For example, data on actual transactions of many self-reporting units are not compiled on a regular basis.

${ }^{8}$ The narrower definition comprises cash transactions that are directly managed by the Accounting General's Office.
} 


\section{Box 1. Structural Conditionality}

\section{Status of structural conditionality}

During July-December 2004, Sierra Leone made some progress in implementing structural reforms under the program, including the parliament's passage of the Budgeting and Accountability Act in February 2005 (see Appendix I, Table 2). However, the structural performance criterion relating to the reconciliation of fiscal and monetary data for 2000-02 was not observed because a full reconciliation proved to be virtually impossible, as the coverage of actual fiscal data was more limited than that of the monetary survey. The government has also completed three other measures as prior actions subject to the sixth review, reflecting their importance for the program. These include the opening of bank accounts for all urban and suburban schools, except mission-operated primary schools, the issuance of identification cards to all civil servants, and the resolution of the matter related to the outstanding domestic arrears to a single creditor. The implementation of four structural benchmarks will be delayed beyond the sixth review, as their effective implementation seems to require a longer time horizon and is heavily dependent on donor assistance.

\section{Structural areas covered by World Bank lending conditionality}

Several reforms were recently completed under the World Bank's Third Economic Rehabilitation and Recovery Credit (ERRC III). These are the creation of a plan for the divesture of public enterprises, an improvement in the business environment through the enactment of an acceptable investment code, the enactment of local government legislation, the strengthening of the financial management system, the development of a program for procurement reform, including enacting a new legislation, the completion of an impact study on the Common External Tariff, the establishment of a cadastre for mining rights, and the piloting of mining sector extension services (Appendix III). Each of these is being deepened, either through the Bank's Institutional Reform and Capacity Building Project (IRCBP) or the pending Fourth Economic Rehabilitation and Recovery Grant.

\section{Status of areas covered by the HIPC Initiative Floating Completion Point}

Sierra Leone has made further progress toward meeting the HIPC Initiative Completion Point triggers, notably related to disarmament and demobilization, decentralization of government functions, education, and health. A full PRSP was circulated to donors on February 9, 2005. Implementation of the PRSP is set to begin in mid-2005, following the Consultative Group meeting in June 2005. Thus, it is expected that Sierra Leone could reach the HIPC Initiative completion point by mid-2006, after one year of successful implementation of the full PRSP. Table 9 provides an update on the status of implementation of the triggers.

\section{Macroeconomic framework for $\mathbf{2 0 0 5}$}

\section{The 2005 macroeconomic framework envisages continued robust output growth} and declining inflation (Table 1). Mining, agriculture, manufacturing, and service are expected to continue driving growth in 2005. The staff is, however, now projecting output growth of 7.5 percent in 2005, instead of 9.4 percent, as envisioned in the staff report for the Article IV consultation (Table 1; Country Report No. 05/23). The lower growth figure reflects delays in restarting the production and export of rutile and bauxite, which are not expected to begin until late 2005. Average inflation has also been revised upward, from 7.3 percent to 8.5 percent, in part as a result of higher fuel costs. Nonetheless, inflation 
in 2005 is projected to come down significantly from its level in 2004 in response to tighter fiscal and monetary policies.

Sierra Leone: Real Sector Indicators, 2005

\begin{tabular}{lcc}
\hline & \multicolumn{2}{c}{2005} \\
\cline { 2 - 3 } & Proj. & Rev. Proj. \\
\hline & (Annual percentage change) 1/ \\
Real GDP & 9.4 & 7.5 \\
GDP deflator & 6.9 & 7.6 \\
Consumer prices (end of period) & 6.5 & 9.0 \\
Consumer prices (period average) & 7.3 & 8.5 \\
\hline
\end{tabular}

Sources: Sierra Leonean authorities; and IMF staff estimates and projections.

$1 /$ Unless otherwise indicated.

\section{Fiscal policy}

16. Fiscal policy in $\mathbf{2 0 0 5}$ aims at promoting macroeconomic stability and mediumterm debt sustainability. The government's fiscal strategy for 2005, which takes a mediumterm perspective in setting expenditure priorities, is reflected in the full PRSP and aims at advancing toward the Millennium Development Goals (MDGs). The overall fiscal deficit (including grants) is projected at 4.6 percent of GDP in 2005 . $^{9}$ This will be higher than the actual outcome for 2004, because of the projected increase in foreign-financed development outlays. The domestic primary deficit, projected at 2.3 percent of GDP, would decline by one-half of a percentage point compared to the 2004 outturn. Domestic financing of the budget is expected to be contained at below 1 percent of GDP. Moreover, external grants and loans are projected at slightly over 5 percent of GDP. This is about 1 percent of GDP less than the outturn for 2004, which was much higher than envisioned under the program. In order to avoid spillovers into domestic financing, the authorities will initially limit expenditure authorizations tied to external budgetary support to 50 percent of the projected support until resources have been received. This approach would facilitate the meeting of adjusted ceilings on net bank credit to the central government, in case an unexpected shortfall in external budgetary support occurs. ${ }^{10}$

\section{Tax efforts and institutional reforms would be continued to enhance revenue} collection in 2005. Domestic revenue is projected to rise to Le 435 billion (13 percent of GDP, up from 12.3 percent in 2004). The 0.7 percentage point of GDP rise in revenue

\footnotetext{
${ }^{9}$ This is lower than the 4.9 percent in the Budget Speech as the latter had assumed that the World Bank budgetary support (equivalent to 0.8 percent of GDP) would be in the form of a loan rather than a grant.

${ }^{10}$ This is also consistent with the adjustor applied to net bank credit to government, which allows 50 percent monetization of a shortfall in external budgetary support.
} 
collection is explained for the most part by an increase in import duties resulting from the rapid import growth projected for 2005 (0.25 percentage point of GDP); the channeling of all nontax revenues through the National Revenue Authority (NRA) nontax revenue department $(0.25 \text { percentage point of GDP })^{11}$; and the strengthening of NRA's revenue administration ( 0.2 percent). The 2005 budget includes 5 percentage point reductions in corporate tax rates and the highest marginal personal income tax rates, to 30 percent, to bring the rates in line with those in neighboring countries (originally envisioned in the context of the 2004 budget, but subsequently postponed). The authorities estimate that the rate reductions will lower domestic revenues by 0.2 percent of GDP. ${ }^{12}$ The authorities also project lower revenues from customs duties, as a result of moving to the Common External Tariff (CET) of the Economic Community of West African States (ECOWAS), with estimated revenue losses of 0.1 percent of GDP in 2005. ${ }^{13}$ To offset the revenue losses fully the authorities have included in the 2005 budget specific measures to raise tax revenues: new taxes on local telephone calls and professional services, reimposition of a 17.5 percent sales tax and a 30 percent excise tax on all tobacco products, elimination of all discriminatory exemptions, removal of zero-rated import duties on raw materials for industries with a market share of at least 60 percent, and imposition of an excise duty on all vehicles older than 10 years. Furthermore, various fees have been raised. These revenue measures are expected to yield Le 9.5 billion $(0.3$ percent of GDP). In order to reflect the related risks for meeting the government's revenue targets the staff, while broadly agreeing with the projections, urged the authorities to review the revenue outturns in mid-2005 and introduce additional revenue measures as may be necessary. The NRA is also in the process of establishing a unit to investigate tax fraud, which is expected to strengthen tax compliance, with fines and penalties for noncompliance increased significantly. $^{14}$

\section{Expenditure trends in the 2005 budget are intended to reflect key development} priorities as outlined in the PRSP. Total expenditures are projected to rise to 27 percent of GDP, owing mainly to the increase in foreign-financed development outlays, but recurrent expenditures are expected to decline to 19.1 percent of GDP, reflecting the tight resource constraint. $^{15}$ The government will contain nonwage recurrent outlays to offset higher wage-

\footnotetext{
${ }^{11}$ Previously, nontax revenue was collected by individual ministries which also spent some of the revenue at their discretion.

12 These new estimates are significantly lower than what the authorities provided to FAD in February 2004, because the revised estimates are based on average, rather than the highest, tax payments in each income bracket.

${ }^{13}$ The full implementation of the CET is expected by end-2007.

14 The authorities estimate that only about 40 percent of corporate taxes are actually paid.

15 Although domestic resources are expected to rise by 1.7 percentage point of GDP in 2005, external budgetary support (grants and loans), including HIPC grants, is projected to fall by 3 percent of GDP compared to the previous year.
} 
related expenditures (see next paragraph) and the cost of servicing domestic debt. However, the government seeks to protect poverty-related outlays and targets to raise their level to 5 percent of GDP, from 4.7 percent in 2004, provided financing from donors is available. To this end, the government plans to request additional donor support in a Consultative Group meeting (to be held in June) to fill the financing gap (equivalent to 0.6 percent of GDP ${ }^{16}$ ) that emerges in the second half of the year. Furthermore, the budget contains a small transfer, Le 17 billion ( 0.5 percent of GDP), to local governments to help finance recurrent operations. The government will also contain nonpriority recurrent expenditures in case the budgeted revenue trends do not materialize. Capital expenditures, domestically and foreign financed, are projected to rise by about 3.3 percent of GDP, reflecting the start of large infrastructure projects financed mainly by donors.

19. A particular challenge to the $\mathbf{2 0 0 5}$ budget has arisen from the wage bill, which has been raised substantially since the presentation of the budget in parliament. The original budget had proposed an increase of 9.5 percent in the wage bill compared with the 2004 outturn, reflecting the additional costs of hiring new teachers $(2,000)$ and police officers $(1,000)$, salary grants to local government employees, and a general salary increase of 4.5 percent. However, following a two-day general strike in January 2005, the government had to concede to the demands of labor unions and increase workers' allowances and thresholds on taxable benefits. The implementation of the agreed increases in the thresholds is projected to lower domestic revenues by 0.2 percent of GDP, while the wage bill is projected to rise by an additional 0.9 percent of GDP. As a result, the wage bill is projected to reach 6.7 percent of GDP in $2005 .{ }^{17}$ The government is seeking to recoup the revenue losses by raising rates and fees on selected services (for example, related to immigration). Regarding expenditure outlays, both recurrent nonwage and noninterest outlays, as well as capital outlays, will be curtailed with a view to maintaining the overall deficit target. The staff agreed with the authorities that the labor demands had threatened state security in a fragile, post conflict environment, leaving the government with little choice. However, the staff stressed that the decision to raise wages had weakened the government's ability to meet poverty-related expenditure targets, and strongly urged the authorities to find a way of agreeing with all stakeholders on how best to address future wage demands within the overall resource constraints (for example, by trying to forge a social contract).

\section{Enhanced privatization revenues should support poverty-related spending and}

domestic debt reduction. The 2005 budget assumes a token amount of revenue (Le 3 billion) from privatization. The government intends to prepare, through the National Commission for Privatization (NCP), several state enterprises for sale in the course of the year, including the Sierra Leone Produce Marketing Board, the Forest Industry Corporation,

\footnotetext{
16 The current PRGF program (ending in June) remains fully financed.

${ }^{17}$ The government also agreed with labor unions to commission a study to provide guidance on the management of the minimum wage.
} 
the Rokel Commercial Bank, the noncore functions of the Sierra Leone Ports Authority, and the National Development Bank. The staff urged the authorities to keep in view the strategic role of privatization and to expedite the implementation of the program, with the objectives of raising additional revenue and enhancing economic efficiency. In case privatization revenues exceed the budgeted amount, the authorities should use additional resources to reduce the domestic debt stock or to increase nonrecurrent poverty-reducing outlays (within the context of the PRSP).

21. The government needs to remain current with its utility bills. While arrears to the National Power Agency (NPA) were cleared in 2003 and the government is now current with its payments to the NPA, outstanding utility arrears are substantial (Le 41.9 billion at end2004), mainly to SierraTel (the main telecommunication company). ${ }^{18}$ The government owes smaller payments to the Guma Valley Water Company and the Sierra Leone Airport Authority. The 2005 budget includes Le 4.5 billion for reducing domestic arrears.

\section{Monetary and financial sector policies}

\section{Monetary policy in $\mathbf{2 0 0 5}$ will continue to remain tight in order to complement}

fiscal policy in reducing inflation. Reserve and broad money are projected to grow at annual rates of 11 and 12 percent, respectively, below that of nominal GDP growth. Monetary expansion will derive mainly from increases in net foreign assets and private sector credit. Staff also reached understandings with the authorities on indicative quarterly monetary targets for 2005. The BSL would conduct, as necessary, open market operations in the primary treasury bill market with a view to absorbing excess liquidity from the banking system. Secondary market trading of treasury bills with commercial banks is unlikely to begin this year, because the BSL has yet to operationalize the liquidity-forecasting framework and electronic book-entry system.

\section{The central bank is also aiming for a slowdown in private sector credit, in part} through increased reserve requirements. The staff welcomes this development, because the recent rise in the ratio of nonperforming loans to total loans is likely associated with the fast-paced expansion of banks' balance sheets. To safeguard the soundness of the banking system, the BSL has to reinforce bank supervision and ensure that banks make adequate provisioning against nonperforming loans and remain well capitalized.

\section{The BSL needs to take additional steps toward implementing International} Financial Reporting Standards, as progress so far has been limited. The Bank's new external auditors, Pannell Kerr Forster (PFK), have provided advice, in the context of the audit of 2003 accounts, on how to comply with international accounting standards (IAS). Furthermore, the staff discussed with the government how it might increase BSL paid-up share capital, which the government has not complied with because of budgetary

${ }^{18}$ Totaling Le 33.5 billion (1.2 percent of GDP) at end-2004. 
constraints. ${ }^{19}$ The BSL is addressing these issues and has requested further technical assistance from the Fund. ${ }^{20}$ The BSL has also requested Fund technical assistance for training staff in risk management, particularly related to foreign exchange. ${ }^{21}$ The computerization of BSL's accounting system to strengthen internal controls is under way.

\section{External sector policies}

\section{The current account deficit is projected to widen in $\mathbf{2 0 0 5}$ as a result of the} importation of large capital items for the rehabilitation of mining operations. The refurbishment of rutile and bauxite facilities is now expected to start in 2005, which will be financed in part by the EU and the Overseas Private Investment Corporation (OPIC), together with an equity stake from the owners. Consequently, mineral exports in 2005 have been revised downward and imports upward compared with the staff's earlier projections. ${ }^{22}$ The external current account (excluding public transfers) is expected to widen to 13 percent of GDP in 2005 from 12 percent in 2004. Gross foreign exchange reserves are projected to decline because external budgetary support is expected to fall, yielding an import cover of 2.8 months. $^{23}$

\section{The authorities are taking steps to strengthen the regulatory environment in the} mineral sector. With a view to enhancing transparency and the business climate in the mineral sector, the authorities have established a law commission (funded by the U.K. Department for International Development, DfID) to bring together the fragmented legal system governing the minerals sector. The authorities are introducing a mining cadastre, with assistance from the World Bank, the United Nations Development Program (UNDP), and the DfID, which is expected to improve the tracking of mining activities in the country. Sierra

\footnotetext{
${ }^{19}$ One way would be through BSL dividends (not paid to government). Section 71 of the Bank of Sierra Leone Act 2000 requires that the minimum paid-up share capital of the central bank should be fully subscribed within five years of the commencement of the act (that is, February 15, 2005). Section 10 stipulates that such paid-up capital shall be Le 50 billion and should be subscribed and held exclusively by the government. Owing to budgetary constraints, the current shortfall is Le 26 billion.

${ }^{20}$ In a letter of December 13, 2004, the BSL informed FIN of the implementation status of pending recommendations of the latest safeguards assessment report.

${ }^{21}$ So far, the BSL has benefited from short-term training programs on foreign exchange management organized by the Bank of England in collaboration with the Bank of Ghana.

${ }^{22}$ This gives rise to a US\$18 million financing gap in 2005, which could be closed with the disbursement from the present arrangement and a possible successor arrangement.

${ }^{23}$ External balance of payments support was US\$143 million in 2004, in part benefiting from an unexpected one-off increase in donor support. It is projected to decline to US\$94 million in 2005 .
} 
Leone ratified the agreement on the certification of the origin of diamond exports in May 2004 (the Kimberley process). In that connection, the authorities have expressed interest in participating in the Extractive Industries Transparency Initiative (EITI) and are seeking technical assistance from the DfID. These reforms in the mining sector are part of a broader effort to attract private investment, including through the implementation of an investment code with World Bank assistance.

27. Paris Club creditors have agreed to extend the consolidation period for debt relief until the current PRGF arrangement expires. Ten out of 11 Paris Club creditors have agreed to provide debt relief on Naples terms. France has agreed to provide debt relief on Cologne terms and has cancelled all pre-cut-off non-Official Development Aid (ODA) debt. Japan has yet to sign a draft agreement on Naples terms. Regarding commercial creditors, Sierra Leone has been engaged in efforts to reach collaborative agreements on the settlement of arrears - including by making goodwill payments to those creditors operating in the country. More recently, the authorities have requested access to the World Bank's debt reduction facility (for IDA-only countries) and have received a favorable response (Box 2). The staff considers that in light of the authorities' efforts to pursue a collaborative approach with private commercial creditors, the authorities meet the good-faith criterion established under the Fund's policy for lending into arrears. 


\section{Box 2. Financing Assurances Review}

- The authorities have continued their efforts to reach agreements with commercial creditors to seek long-term rescheduling of verified debt aimed at obtaining terms no less favorable than those provided by the Paris Club and under the Enhanced HIPC Initiative.

- In September 1995, the World Bank-sponsored buyback extinguished about US\$235 million in debt. There remains, however, a substantial amount of outstanding claims to commercial creditors owing partly to the nonparticipation of some creditors in the 1995 buyback program and partly to the late submission of claims.

- The authorities have engaged those creditors on several occasions and are making goodwill payments to creditors that are operating in the country in order to ensure completion of important infrastructure projects. Nonetheless, the authorities have not succeeded in reaching debtrescheduling agreements with commercial creditors at terms comparable to the signed Paris Club agreements and consistent with the Enhanced HIPC Initiative. Some creditors have also threatened to resort to litigation to advance their interests.

- The authorities have recently made a request to access the World Bank's debt reduction facility (for IDA-only countries), and have obtained a favorable response. A debt buyback would be priced on the total outstanding debt, including late interest and penalty, with prices set below the net present value (NPV) equivalent of the full provision of traditional Paris Club and Enhanced HIPC Initiative relief. Preliminary estimates indicate that about US\$175 million in debt could be extinguished under the latest operation.

- Notwithstanding threats of litigation by external private creditors, developments in creditor-debtor relations have not undermined program implementation, and do not risk safeguarding Fund resources.

\section{Structural reforms}

\section{To accelerate the implementation of structural reforms under the PRGF} arrangement, the authorities have completed four measures as prior actions to the sixth review. As a corrective action for the nonobservance of the structural performance criterion on the reconciliation of fiscal and monetary data for 2000-02, the authorities have completed the reconciliation of fiscal and monetary data for 2001-04 using a narrower definition of government than originally envisioned (see Section II). Furthermore, the government is in the process of revamping the fiscal and monetary reporting system with technical advice from the Fund. ${ }^{24}$ The framework would facilitate fuller fiscal and monetary data reconciliation and is intended to be in place in early 2006.

\footnotetext{
${ }^{24} \mathrm{~A}$ follow-up visit by an expert took place in February 2005.
} 


\section{Because of the overall importance for the program the following three other measures have been completed as prior actions:}

- All urban and suburban schools, except mission-operated primary schools, have opened individual bank accounts for the payment of teachers' salaries.

- The terms and conditions governing the securitization of all remaining domestic arrears have been announced publicly.

- Identification cards were issued to all civil servants by April 15, 2005.

30. Regarding the opening of school bank accounts, the staff agreed with the authorities that this measure needed to be modified to reflect the limited banking network outside urban areas. The modification, following a meeting between the government and heads of schools (also attended by the staff), is that all schools in urban and suburban areas, except missionoperated primary schools, will be paid through bank accounts. This action was completed in April. Other schools (such as feeder and newly opened schools) are paid by crossed checks that must be deposited in bank accounts operated by agencies administering groups of schools. $^{25}$

31. On the stock of domestic arrears, the government has implemented its decision to pay small creditors in cash. In respect of one large claimant, the government has analyzed and discussed, through a Cabinet paper, the legal and other questions that had been raised on the claim. ${ }^{26}$ In April, the government decided that the claim could not be accepted as legitimate and conveyed this decision to the claimant.

\section{The completion of other structural benchmarks will be postponed until after the} current program ends (Appendix I, Table 2). The postponement reflects, in part, the ambitious reform agenda that was envisioned in the PRGF arrangement. ${ }^{27}$ Furthermore, it is now realized that effective implementation will require a longer time horizon and will be substantially dependent on donor support (in particular, from the DfID). The main donors agree with this view on the progress so far and on the constraints. The DfID is providing support for three benchmarks related to strengthening the Auditor General's office, which has started and is ongoing; converting the Establishment Secretary's office into a human resource management office; and, together with the UNDP, reforming six key ministries (for which diagnostic studies have been completed, with the reforms under way). The authorities

\footnotetext{
${ }^{25}$ For mission-operated primary schools, which are paid through group bank accounts, the banks have been hesitant to allow individual accounts. These accounts would also be relatively costly to the individual schools.

${ }^{26}$ The latest estimate for the claim is Le 51.2 billion (1.5 percent of 2005 GDP).

27 See also the ex post assessment report (www.imf.org).
} 
have requested additional technical assistance from the Fund to advance the medium-term budgetary framework for the mineral sector. The implementation of these measures could be revisited in the context of a possible successor arrangement with the Fund.

\section{PRSP process}

33. The authorities finalized a full PRSP in February 2005. The staffs of the Fund and the World Bank have issued a joint staff advisory note (JSAN) assessing the government's poverty-reduction strategy. ${ }^{28}$ The staff considers that the full PRSP provides an appropriate framework for the government's efforts to alleviate poverty. However, more work would be needed to align the budget with the PRSP, clarify expenditure priorities in light of existing fiscal constraints, and build adequate capacity for effective monitoring and implementation (Box 3). A Consultative Group meeting with donors in Paris is scheduled for early June 2005, during which the government will seek financing for the PRSP activities. At the meeting, the authorities will also request donors to fill the significant financing gap that has emerged as a result of the commitment to raise the level of poverty-related spending. ${ }^{29}$

\section{Data issues}

\section{Significant improvements are still needed in Sierra Leone's macroeconomic} database. ${ }^{30}$ While progress has been made in a number of areas, with technical assistance from the Fund and other donors, capacity and resource constraints remain and impede timely provision of data for program monitoring and surveillance. The Fund is assisting Statistics Sierra Leone in enhancing the coverage and quality of national accounts data ${ }^{31}$ and improving the construction of the consumer price index. Other areas benefiting from Fund technical assistance are the targeted improvements in the coverage and quality of fiscal and monetary data and the compilation of balance of payments statistics in the context of the General Data Dissemination System (GDDS) project.

\footnotetext{
${ }^{28}$ See www.imf.org.

${ }^{29}$ Poverty-related expenditures are projected to rise to 5 and $5 \frac{1}{2}$ percent of GDP in 2005 and 2006, respectively.

${ }^{30}$ See Appendix IV for further details.

${ }^{31}$ A national account expert visited Freetown in April and September 2004 and in February 2005 under the GDDS project.
} 


\section{Box 3. The Integration of the GDDS in the PRSP}

Sierra Leone became a participant in the General Data Dissemination System (GDDS) in 2003. Along with 14 countries, it is participating in the GDDS Anglophone Africa Project through short-term technical assistance and regional cooperation. ${ }^{1}$ It is expected that Sierra Leone's participation in the GDDS will improve the quality of its data and that its weak statistical infrastructure will benefit from enhanced domestic and external support, especially aimed at facilitating the monitoring of the PRSP.

The Sierra Leone PRSP is an innovative approach for incorporating elements of the GDDS. The effort comprises a systematic diagnosis of the statistical system along with the formulation of a capacitybuilding plan for statistical development. The GDDS plan for improvement has been integrated with the other statistical requirements of the PRSP, which have been costed and will be reflected in the annual budgets. This should help in identifying the funding requirements for GDDS/PRSP statistical reforms.

The PRSP acknowledges in a separate section, "Empowerment with Statistics," the central role of statistics in supporting the overall poverty strategy, including the pursuit of the MDGs. Such an approach is all the more important, given that Sierra Leone's capacity for production, management, and analysis of statistics suffered gravely during the past decades of economic deterioration and civil war. The development of the statistical system and the strengthening of the statistical agency, Statistics Sierra Leone, are expected to benefit from technical assistance, including from the Fund.

The indicative cost estimates for the development of statistics will form an integral part of the overall costing of the first pillar of Sierra Leone's poverty reduction strategy ("Good governance, Peace, and Security"). The cost estimates for the development of a national statistical system, the operations of Statistics Sierra Leone, and the conducting of the system of annual surveys amount to US $\$ 10.8$ million (or 1 percent of 2005 GDP) during the three-year PRSP implementation period (2005-07); the financing sources for 85 percent of this amount still needs to be identified.

${ }^{1}$ The project, which is funded by DfID, was extended by two years through April 2006 and is administered jointly by the Fund and the World Bank.

\section{The ex post assessment}

\section{The authorities broadly concurred with the conclusions of the EPA of the Fund's} engagement with Sierra Leone since 1994. In particular, they agreed that the design of Fund-supported programs had been broadly appropriate, and they appreciated the rationale for Fund involvement in the country in light of the underlying balance of payments need and external risks. The authorities felt that the Fund's involvement had played a very positive role in terms of helping with macroeconomic stabilization, providing a framework for policy implementation, building much-needed capacity through technical assistance in the aftermath of the conflict, and catalyzing donor support.

36. The authorities provided their perspectives on a few specific aspects of Fundsupported programs. In their view, the transition from Emergency Post-Conflict Assistance 
(EPCA) to PRGF support had been relatively rapid ${ }^{32}$. EPCA purchases, being nonconcessional, were relatively expensive while purchases under the PRGF were concessional but entailed more conditionality. In the end, because of resource constraints, they decided to request support under a PRGF arrangement, but the conditionality posed a challenge for the existing capacity. In addition, the authorities felt that donor coordination had generally been weak and had introduced unpredictability in budgetary planning and at times squeezed social expenditures.

\section{Looking ahead, the authorities strongly supported an early move to a successor}

Fund-supported program. They agreed that such a move was justified by the substantial financing gap that needed to be filled in order for them to make substantive progress toward the MDGs and by the range of external risks that Sierra Leone continued to face. In addition, the authorities shared the view that a prolonged delay in Fund involvement would have substantial costs, including in terms of HIPC Initiative debt relief, possibly other donor support, and the overall economic situation. The authorities also supported the recommendation in the EPA that the Fund remain closely involved in providing technical assistance to strengthen capacity, and they highlighted economic statistics and governance as two key areas. They felt that greater donor coordination would be important for strengthening both the effectiveness of technical assistance and macroeconomic management.

\section{Program Monitoring}

38. The authorities are requesting waivers for the nonobservance of the quantitative performance criterion on the domestic primary fiscal balance and for the structural performance criterion on the reconciliation of fiscal and monetary data for 2000-02. The quantitative performance criterion (floor) was marginally missed because of higher-thanprogrammed outlays for the wage bill and goods and services. The outcome reflects, in part, continued capacity constraints that make it difficult for the authorities to manage payroll and other outlays adequately. To strengthen payroll management and the budget process, the DfID is providing technical assistance to the authorities, under a three-year program. The structural performance criterion was not observed because of fiscal data limitations that made it impossible to implement the measure in its original form. Instead, the authorities have completed the reconciliation of fiscal and monetary data using a narrower definition of government for 2001-04 as a prior action subject to the sixth review under the PRGF arrangement. Furthermore, the Fund is providing technical advice to the authorities to

\footnotetext{
${ }^{32}$ In response to the staff's observation that Sierra Leone's experience under the EPCA (three years) had, in fact, been relatively long in comparison with other post-conflict countries, the authorities noted that each of the annual EPCA arrangements had been interrupted by conflict. The time between the last episode of violence and the initiation of the PRGF was, in fact, less than a year.
} 
revamp the fiscal and monetary reporting system, which should address weaknesses in fiscal and monetary reporting going forward.

39. The mission reached understandings with the authorities on indicative quarterly targets for 2005 on net domestic bank credit to the government, net domestic assets of the BSL, the domestic primary balance of the government, and the BSL's gross international reserves. These would serve as a basis for program targets under a possible successor arrangement, subject to revisions as more recent data becomes available. ${ }^{33}$ Current adjusters on the target variables as presented in the technical memorandum of understanding (October 2004) and the technical correction to a performance criterion (December 2004) would continue to apply.

\section{StAFF ApPraisal}

40. While broad-based growth has continued, inflation has risen steadily and poverty remains widespread. With strong output gains expected in 2005 and beyond, Sierra Leone's main challenge is to keep inflation under control while supporting an expansion in real activity. With respect to poverty and high unemployment, the full PRSP is underpinned by three strategic pillars: the promotion of good governance and security; the fostering of pro-poor growth for food security and job creation; and the development of human resources. Domestic resource mobilization and assistance from donors will be critical not only for successfully implementing medium-term poverty-reduction programs but also for enabling Sierra Leone to advance toward longer-term goals (the MDGs). The authorities plan to seek support for the PRSP activities at the June 2005 Consultative Group meeting in Paris.

\section{Performance under the program at end-2004 was mixed; however, the} authorities have taken steps to address the shortcomings. The 2005 budget has been framed within the context of medium-term fiscal sustainability, reflecting the authorities continuing drive to reduce fiscal deficits and macroeconomic imbalances. The unforeseen demand from the wage-related agreement in January 2005 is not expected to affect the overall fiscal deficit, as nonwage outlays will be curtailed to offset the planned increase in the wage bill. However, staff is very concerned that, as a result of the large wage increase, poverty-related outlays would decline in relation to GDP, unless additional donor support is found. While recognizing the pressures faced by the authorities, large increases in the public sector wage bill are inconsistent with the needs of an effective poverty-reduction strategy and must be avoided in the future. Progress has also been made in implementing the program structural measures, some as prior actions, but further actions will need to be taken, possibly in the context of a successor PRGF arrangement.

\footnotetext{
${ }^{33}$ Discussions with the authorities on a new arrangement are tentatively scheduled to commence in June 2005.
} 
42. With sustained efforts on macroeconomic and structural policies as well as continued donor support, Sierra Leone's medium-term economic prospects should be promising. The EPA provides a positive basis for contemplating continued Fund support in these overall efforts. On these considerations, the following four areas need the specific attention of the authorities.

43. First, fiscal policy should increasingly aim at playing a central role in supporting macroeconomic stability. Owing to the relatively large demands on limited resources, the government needs to ensure that domestic revenue targets are met and that expenditures are adequately prioritized and closely monitored. On the revenue side, the authorities need to continue their efforts to strengthen tax administration and domestic revenue collection. In addition, they need to finalize, as a matter of urgency, the medium-term fiscal framework for the mineral sector. On the expenditure side, the authorities also need to institutionalize the practice of cautiously matching expenditures to expected external budgetary support in order to contain domestic financing of the budget. With respect to wage-related demands, the authorities should work to ensure that these demands can be contained, possibly through political and social compacts, and that the increase agreed in January does not foreshadow future wage increases. Otherwise, macroeconomic stability and poverty-related objectives could be compromised.

\section{Second, monetary policy should be more proactive, although its effectiveness} significantly depends on supportive fiscal policy. The BSL should continue to widen its menu of monetary instruments, in part through the Fund's ongoing technical assistance. In addition, the rise in the proportion of nonperforming commercial bank loans calls for further restraint in the expansion of private-sector credit and for closer supervision of the banks by the BSL. In this context, the forthcoming MFD mission to Sierra Leone will examine the health of the banking system. Reflecting the findings of the mission, the BSL should stand ready to take timely action to ensure that prudential regulations are strictly enforced.

\section{Third, strong sustained growth will require continued structural reforms,} including those related to the enhancement of the investment climate. The outstanding elements of the current reform agenda, which, under the PRGF arrangement focuses on strengthening public sector management, need to be finalized. The staff and donors now agree that most of these reforms will take longer (about two years) to implement. As the public sector continues to be strengthened, the reform efforts could increasingly be shifted toward attracting private investment (domestic and foreign).

46. Fourth, the country's statistical database needs further strengthening to enhance the monitoring of future programs and PRSP-related activities. The steps being taken to revamp the system of reporting fiscal and monetary data are especially important and require timely conclusion. In this regard, the staff welcomes the positive outcome of the April 2005 seminar organized by STA in Freetown, which brought together all concerned parties and reached agreement on the work plan for the coming months. Similarly, improvements in the compilation of national accounts statistics, being introduced with Fund technical assistance, 
and in other PRSP-related areas would greatly assist the authorities in monitoring progress in poverty-reduction efforts.

47. On the basis of the measures taken by the authorities, the staff recommends that the Executive Board grant waivers for the nonobservance of two performance criteria and complete the sixth program and financing assurances review. During the second half of 2004, the authorities took measures to contain fiscal expenditures and mobilize budgetary support, and the 2005 budget aims at promoting macroeconomic stability and debt sustainability. Furthermore, the authorities have implemented the prior actions subject to the sixth review of the PRGF arrangement. The staff, therefore, recommends that the Executive Board grant a waiver for the nonobservance of the quantitative performance criterion at endDecember 2004 on the government domestic primary budget balance. The margin of the nonobservance of this criterion was minor. The staff also recommends that the Board grant a waiver for the nonobservance of the structural performance criterion on the reconciliation of fiscal and monetary data for 2000-02. The partial reconciliation of 2001-04 fiscal and monetary data was completed as a corrective action for the nonobservance of the structural performance criterion. Based on the commitments made in the attached letter of intent, the staff recommends completion of the sixth review under the PRGF arrangement. In view of the authorities' good faith efforts in negotiating with commercial creditors, the staff also recommends completion of the financing assurances review. Furthermore, other creditors have continued to provide satisfactory assurances of their continued assistance to Sierra Leone. The Paris Club creditors have agreed to extend the consolidation period for debt relief until the expiration of the current PRGF arrangement. In light of this, and because of the exceptional circumstances of Sierra Leone's vulnerable external position and the need to smooth out Sierra Leone's principal payments to the Fund, the staff supports advancing additional interim HIPC Initiative assistance under the enhanced HIPC Initiative for the period up to December 2005. In addition, based on the conclusions of the EPA of the Fund's engagement with Sierra Leone, the staff considers that a follow-up PRGF arrangement would be appropriate, provided the policies are adequate. 
Figure 1: Inflation and Money Growth, January 2004-February 2005 (In percent; year-on-year changes)

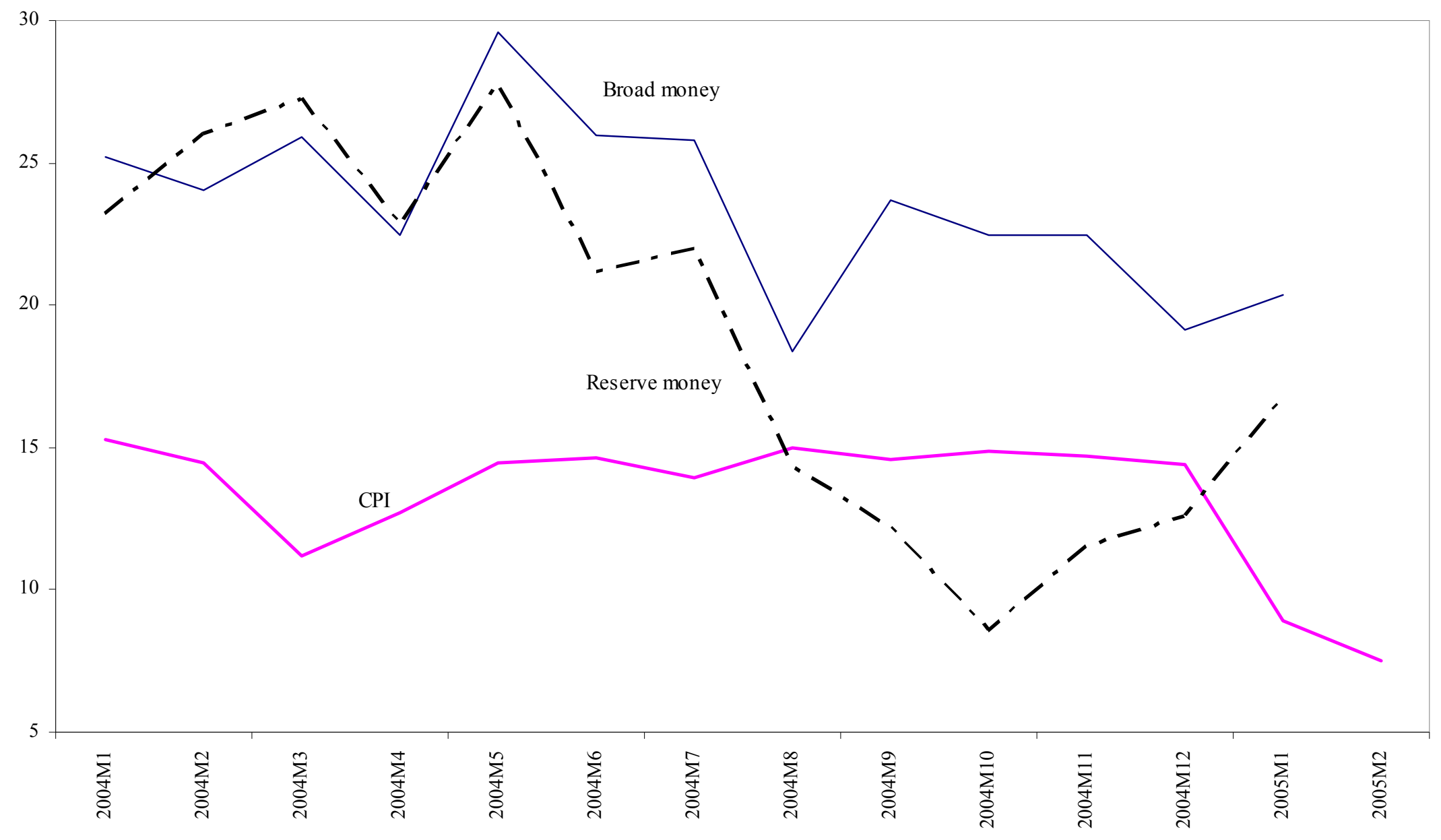

Sources: Sierra Leonean authorities; and IMF staff estimates. 
Figure 2. Sierra Leone: Nominal and Real Effective Exchange Rates, January 2000- December 2004 1/ $(1995=100)$

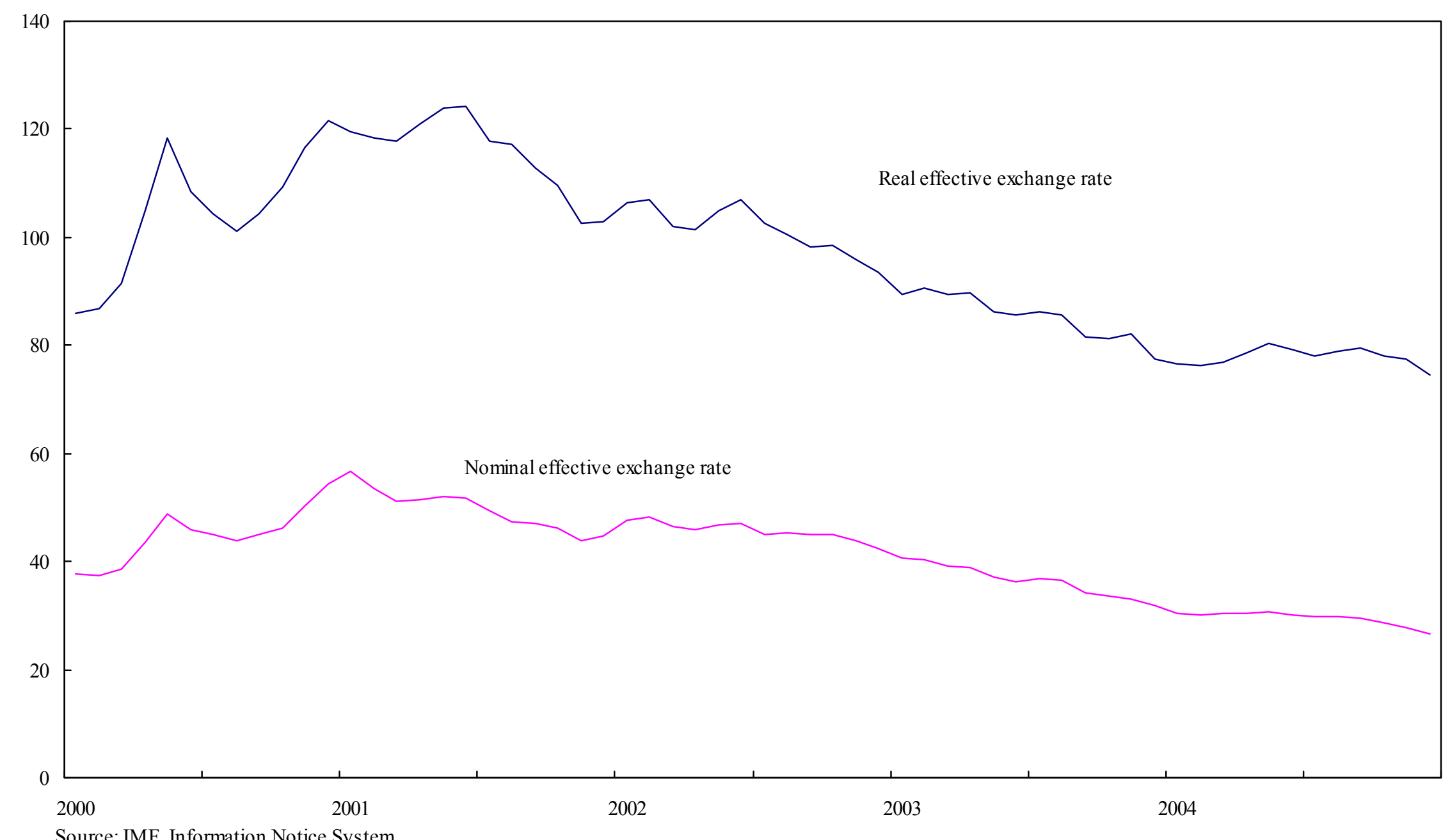


Table 1. Sierra Leone: Selected Economic and Financial Indicators, 2001-07

\begin{tabular}{|c|c|c|c|c|c|c|c|c|c|}
\hline & \multirow{2}{*}{$\begin{array}{r}2001 \\
\text { Act. } \\
\end{array}$} & \multirow{2}{*}{$\begin{array}{r}2002 \\
\text { Est. }\end{array}$} & \multirow{2}{*}{$\begin{array}{r}2003 \\
\text { Est. } \\
\end{array}$} & \multicolumn{2}{|c|}{2004} & \multicolumn{2}{|c|}{2005} & \multirow{2}{*}{$\begin{array}{l}2006 \\
\text { Proj. }\end{array}$} & \multirow{2}{*}{$\begin{array}{l}2007 \\
\text { Proj } \\
\end{array}$} \\
\hline & & & & Prog 1/ & Proj. & Proj. 1/ & Rev. Proj. & & \\
\hline & \multicolumn{9}{|c|}{ (Annual percentage change, unless otherwise indicated) } \\
\hline \multicolumn{10}{|l|}{ Income and expenditure } \\
\hline Real GDP $2 /$ & 18.2 & 27.5 & 9.3 & 7.4 & 7.4 & 9.4 & 7.5 & 7.1 & 6.5 \\
\hline GDP deflator & 1.8 & -3.6 & 8.2 & 14.4 & 16.0 & 6.9 & 7.6 & 5.8 & 4.7 \\
\hline Nominal GDP & 20.3 & 22.8 & 18.3 & 22.8 & 24.6 & 17.0 & 15.8 & 13.3 & 11.5 \\
\hline Consumer prices (end of period) & 3.4 & -3.1 & 11.3 & 12.8 & 14.4 & 6.5 & 9.0 & 6.0 & 5.5 \\
\hline Consumer prices (annual average) & 2.6 & -3.7 & 7.5 & 12.4 & 14.2 & 7.3 & 8.5 & 7.4 & 5.7 \\
\hline \multicolumn{10}{|l|}{ Money and credit } \\
\hline \multicolumn{10}{|l|}{ Broad money } \\
\hline (including foreign currency deposits) & 33.7 & 30.1 & 26.2 & 13.8 & 18.9 & 16.5 & 11.6 & 13.1 & 11.6 \\
\hline (excluding foreign currency deposits) & 30.8 & 32.0 & 25.6 & 11.3 & 16.9 & 16.6 & 11.6 & 13.1 & 11.6 \\
\hline Velocity (level; excl. foreign currency deposits) & 6.5 & 6.1 & 5.7 & 6.5 & 6.1 & 6.5 & 6.3 & 6.3 & 6.3 \\
\hline Velocity (level; incl. foreign currency deposits) & 5.5 & 5.2 & 4.9 & 5.3 & 5.1 & 5.4 & 5.3 & 5.3 & 5.3 \\
\hline Domestic credit $3 /$ & 22.5 & 7.9 & 27.5 & 6.3 & -2.1 & 6.6 & 8.6 & 6.7 & 3.7 \\
\hline Government 3/ & 19.4 & 0.2 & 17.1 & -2.0 & -10.9 & 2.7 & 2.2 & 0.8 & -0.9 \\
\hline Private sector $3 /$ & 3.2 & 7.5 & 9.7 & 8.4 & 8.8 & 3.8 & 6.4 & 5.9 & 4.6 \\
\hline (annual percentage change) & 24.6 & 62.3 & 64.5 & 42.0 & 45.2 & 15.5 & 27.0 & 21.7 & 15.8 \\
\hline Reserve money & 29.4 & 24.9 & 22.4 & 6.4 & 12.6 & 15.9 & 10.5 & 12.3 & 10.9 \\
\hline Interest rate $4 /$ & 14.7 & 15.0 & 20.2 & 27.0 & 28.0 & 17.3 & 18.5 & 17.4 & 15.7 \\
\hline \multicolumn{10}{|l|}{ External sector } \\
\hline Exports (U.S. dollars) & 6.1 & 48.9 & 27.4 & 26.2 & 17.4 & 33.9 & 18.5 & 33.8 & 15.2 \\
\hline Imports (U.S. dollars) 5/ & 20.6 & 54.4 & 15.6 & 22.7 & -9.7 & 4.9 & 17.6 & 12.3 & 9.6 \\
\hline Terms of trade (- deterioration) & 2.4 & 0.0 & -1.9 & -2.0 & -4.6 & 0.9 & 2.4 & 4.4 & 2.7 \\
\hline \multirow[t]{2}{*}{ Real effective exchange rate (- depreciation; end of period) } & -15.3 & -9.7 & -17.2 & $\ldots$ & -4.3 & $\ldots$ & $\ldots$ & $\ldots$ & $\ldots$ \\
\hline & \multicolumn{9}{|c|}{ (In percent of GDP) } \\
\hline Gross domestic investment & 7.6 & 10.1 & 14.3 & 21.1 & 19.6 & 19.9 & 20.7 & 21.0 & 21.1 \\
\hline Government & 4.4 & 4.4 & 4.8 & 8.8 & 8.8 & 7.3 & 7.4 & 8.0 & 8.1 \\
\hline Private & 3.1 & 5.7 & 9.4 & 12.3 & 10.8 & 12.7 & 13.3 & 13.1 & 13.0 \\
\hline Gross national saving & -9.9 & 5.3 & 6.7 & 9.7 & 14.7 & 11.7 & 12.7 & 14.8 & 16.3 \\
\hline Gross domestic saving & -10.0 & -9.4 & -7.0 & -1.8 & 2.8 & 2.7 & 3.6 & 7.3 & 8.6 \\
\hline Government & -3.2 & -4.3 & -3.2 & -1.2 & -1.2 & -0.5 & 0.0 & 1.3 & 2.3 \\
\hline Private & -6.8 & -5.1 & -3.8 & -0.6 & 4.1 & 3.2 & 3.6 & 6.0 & 6.3 \\
\hline Current account balance, including official transfers & -17.4 & -4.8 & -7.6 & -11.4 & -4.9 & -8.3 & -8.0 & -6.2 & -4.8 \\
\hline Current account balance, excluding official transfers & -22.0 & -12.1 & -14.1 & -17.5 & -11.7 & -13.6 & -13.0 & -10.2 & -9.0 \\
\hline Goods and nonfactor services (net) & -19.6 & -19.5 & -21.3 & -22.9 & -16.7 & -17.2 & -17.2 & -13.8 & -12.5 \\
\hline Unrequited private transfers and factor services (net) & -3.5 & 7.1 & 7.0 & 5.2 & 4.7 & 3.4 & 3.9 & 3.3 & 3.2 \\
\hline Overall balance of payments & 1.7 & -0.3 & -4.6 & -2.6 & 1.5 & -4.3 & -5.8 & -4.3 & -2.3 \\
\hline Government domestic revenue & 13.0 & 12.1 & 12.4 & 12.0 & 12.3 & 12.9 & 13.0 & 14.7 & 15.8 \\
\hline Total expenditure and net lending & 29.5 & 28.6 & 26.9 & 28.4 & 24.8 & 26.3 & 27.0 & 26.4 & 25.9 \\
\hline Of which: current expenditure & 24.8 & 24.2 & 22.1 & 19.6 & 20.2 & 19.0 & 19.1 & 18.3 & 17.7 \\
\hline Overall fiscal balance & & & & & & & & & \\
\hline (commitment basis, excluding grants) & -16.5 & -16.5 & -14.5 & -16.4 & -12.5 & -13.4 & -14.0 & -11.8 & -10.1 \\
\hline (commitment basis, including grants) & -10.6 & -8.3 & -6.7 & -7.4 & -3.5 & -5.3 & -4.6 & -4.5 & -2.8 \\
\hline Domestic primary fiscal balance 6 / & -7.7 & -7.0 & -5.6 & -2.8 & -2.8 & -2.3 & -2.3 & -1.4 & -0.9 \\
\hline Domestic financing & 3.2 & 0.9 & 4.3 & 1.5 & -0.1 & 1.8 & 0.9 & 0.4 & -0.3 \\
\hline Financing gap $7 /$ & $\ldots$ & $\ldots$ & $\ldots$ & $\ldots$ & $\ldots$ & $\ldots$ & 0.6 & 0.5 & $\ldots$ \\
\hline & & & & ent of exp & ods and 1 & tor services & & & \\
\hline Debt service due (incl. to the Fund) after debt relief 8 / & 73.0 & 9.3 & 7.3 & 10.4 & 9.9 & 7.6 & 14.7 & 2.0 & 2.8 \\
\hline Debt service due (incl. to the Fund) before debt relief & 86.0 & 52.7 & 48.1 & 38.6 & 37.2 & 28.2 & 29.4 & 18.7 & 18.9 \\
\hline Net present value of debt-to-exports ratio $9 / 10 /$ & 150.6 & 162.3 & 153.6 & 153.3 & 151.3 & 144.7 & 147.3 & 138.6 & 135.2 \\
\hline & & & & ons of U.S & unless o & se indicated & & & \\
\hline Memorandum items: & & & & & & & & & \\
\hline External current account balance, excluding & & & & & & & & & \\
\hline official transfers & -165.0 & -113.6 & -139.7 & -185.2 & -122.3 & -157.5 & -151.3 & -129.1 & -123.7 \\
\hline Gross international reserves & 51.9 & 84.6 & 59.4 & 81.9 & 124.9 & 111.9 & 123.1 & 143.1 & 163.1 \\
\hline (in months of imports) 11/ & 1.9 & 2.5 & 1.7 & 2.0 & 3.1 & 2.6 & 2.8 & 3.0 & 3.2 \\
\hline GDP (billions of leones) & $1,600.2$ & $1,964.6$ & $2,323.6$ & $2,854.5$ & $2,894.1$ & $3,338.7$ & $3,350.0$ & $3,796.4$ & 4,234.2 \\
\hline GDP (millions of U.S. dollars) & 805.6 & 936.0 & 989.6 & $1,043.7$ & $1,075.4$ & $1,160.1$ & $1,136.4$ & $1,233.6$ & $1,336.4$ \\
\hline
\end{tabular}

Sources: Sierra Leonean authorities; and IMF staff estimates and projections.

1/ As in IMF Country Report No. 05/23. Ratios as a percent of nominal GDP reflect revised national GDP data.

2/ Based on the trend in growth of real GDP, nominal GDP is not expected to reach the prewar 1996 level of US\$941.7 million until 2005.

3/ Changes as a percentage of beginning-of-period money stock (including foreign currency deposits).

4/ Treasury bill rate (end of period); in percent.

5/ Includes imports purchased with bilateral aid, those related to rehabilitation and reconstruction programs, and imports of embassies and the UN peacekeeping force (UNAMSIL).

6/ Domestic revenue minus total expenditure and net lending, excluding interest payments, and externally financed capital expenditure and disarmament,

demobilization, and reintegration (DDR) program.

7/ Financing gap in 2005-06 relates to the unidentified financing for poverty-related expenditures.

8/ As a percent of exports of goods and services; after Naples (2001) and Cologne flow reschedulings (2002-04), and delivery of full HIPC Initiative assistance.

9/ Net present value (NPV) of debt relative to backward-looking three-year average of exports of goods and services.

10/ Assumed unconditional delivery of enhanced HIPC Initiative assistance in 2000.

11/ In months of imports of goods and services of subsequent year. 
Table 2. Sierra Leone: Central Government Financial Operations, 2001-05 1/

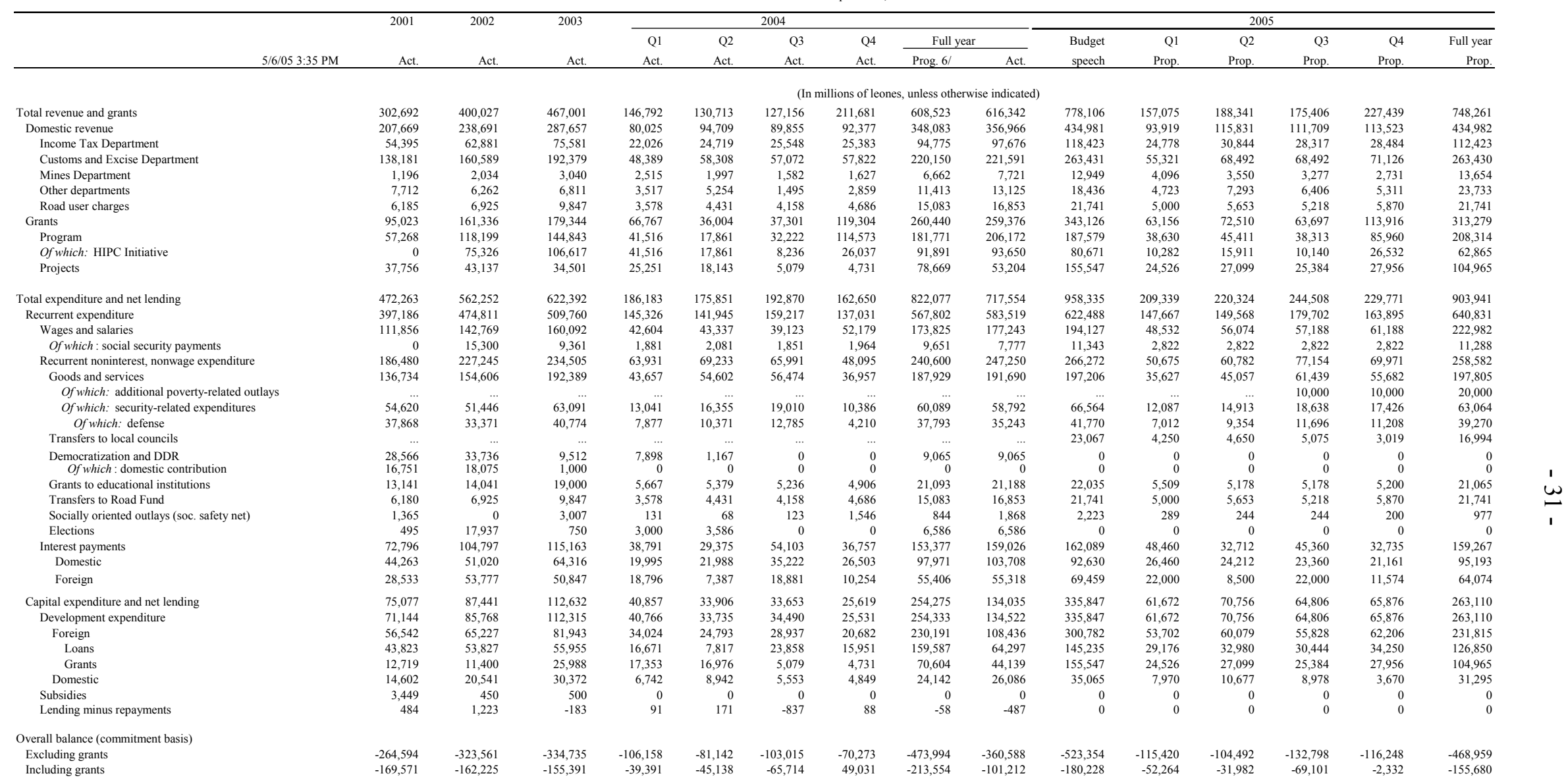


Table 2. Sierra Leone: Central Government Financial Operations, (concluded) 2001-05 1/

\begin{tabular}{|c|c|c|c|c|c|c|c|c|c|c|c|c|c|c|c|}
\hline & \multirow{3}{*}{$\begin{array}{l}2001 \\
\text { Act. }\end{array}$} & \multirow{3}{*}{$\begin{array}{r}2002 \\
\text { Act. } \\
\end{array}$} & \multirow{3}{*}{$\begin{array}{r}2003 \\
\text { Act. } \\
\end{array}$} & \multicolumn{6}{|c|}{2004} & \multicolumn{6}{|c|}{2005} \\
\hline & & & & \multirow{2}{*}{$\begin{array}{r}\text { Q1 } \\
\text { Act. }\end{array}$} & \multirow{2}{*}{\multicolumn{2}{|c|}{$\begin{array}{r}\text { Q3 } \\
\text { Act. } \\
\end{array}$}} & \multirow{2}{*}{$\begin{array}{r}\text { Q4 } \\
\text { Act. }\end{array}$} & \multicolumn{2}{|c|}{ Full year } & \multirow{2}{*}{$\begin{array}{l}\text { Budget } \\
\text { speech }\end{array}$} & \multirow{2}{*}{$\begin{array}{r}\text { Q1 } \\
\text { Prop. }\end{array}$} & \multirow{2}{*}{$\begin{array}{r}\text { Q2 } \\
\text { Prop. } \\
\end{array}$} & \multirow{2}{*}{$\begin{array}{r}\text { Q3 } \\
\text { Prop. }\end{array}$} & \multirow{2}{*}{$\begin{array}{r}\text { Q4 } \\
\text { Prop. }\end{array}$} & \multirow{2}{*}{$\begin{array}{r}\text { Full year } \\
\text { Prop. }\end{array}$} \\
\hline & & & & & & & & Prog. 6/ & Act. & & & & & & \\
\hline & \multicolumn{15}{|c|}{ (In millions of leones, unless otherwise indicated) } \\
\hline 'otal financing & 169,571 & 162,225 & 155,391 & 39,391 & 45,138 & 65,714 & $-49,031$ & 213,554 & 101,212 & 180,228 & 52,264 & 31,982 & 69,101 & 2,332 & 155,680 \\
\hline Foreign & 624,766 & 143,734 & 66,764 & 18,386 & 23,017 & 25,314 & 44,054 & 199,384 & 110,772 & 147,100 & 15,376 & 19,719 & 57,744 & 13,450 & 106,289 \\
\hline Borrowing & 95,370 & 141,605 & 93,628 & 16,671 & 33,823 & 37,270 & 63,207 & 240,174 & 150,971 & 204,235 & 29,176 & 32,980 & 59,944 & 34,250 & 156,350 \\
\hline Project & 43,823 & 53,827 & 55,955 & 16,671 & 7,817 & 23,858 & 15,951 & 159,587 & 64,297 & 145,235 & 29,176 & 32,980 & 30,444 & 34,250 & 126,850 \\
\hline Program & 51,547 & 87,778 & 37,673 & 0 & 26,006 & 13,412 & 47,256 & 80,587 & 86,674 & 59,000 & 0 & 0 & 29,500 & & 29,500 \\
\hline Amortization 2/ & $-38,515$ & $-48,284$ & $-89,590$ & $-38,927$ & $-19,639$ & $-46,089$ & $-21,969$ & $-126,857$ & $-126,625$ & $-155,984$ & $-58,400$ & $-21,669$ & $-47,100$ & $-25,700$ & $-152,869$ \\
\hline Change in foreign arrears & & & $-51,146$ & $-4,004$ & $-21,089$ & 0 & 0 & $-25,806$ & $-25,093$ & 0 & 0 & 0 & 0 & 0 & \\
\hline Debt relief obtained 2/3/ & 567,911 & 50,413 & 113,871 & 44,646 & 29,922 & 34,133 & 2,817 & 111,873 & 111,518 & 98,849 & 44,600 & 8,408 & 44,900 & 4,900 & 102,808 \\
\hline Domestic & 51,791 & 18,600 & 100,104 & 26,204 & 29,666 & 30,339 & $-88,316$ & 41,975 & $-2,107$ & 34,628 & 38,438 & 14,513 & 557 & $-22,618$ & 30,890 \\
\hline Of which: bank & 42,197 & 601 & 56,074 & 22,196 & 10,980 & 11,262 & $-96,073$ & $-9,255$ & $-51,635$ & 14,628 & 15,375 & 5,805 & 223 & $-9,047$ & 12,356 \\
\hline Privatization receipts & 2,060 & 472 & 270 & 26 & 26 & 0 & 0 & 52 & 52 & 3,000 & 0 & 0 & 1,500 & 1,500 & 3,000 \\
\hline Change in arrears & $-533,199$ & $-3,586$ & $-13,539$ & $-1,785$ & $-2,010$ & $-2,438$ & $-1,128$ & $-7,045$ & $-7,361$ & $-4,500$ & $-1,550$ & $-2,250$ & -700 & 0 & $-4,500$ \\
\hline Unaccounted ( $-=$ overfinancing of the budget) & 24,152 & 3,004 & 1,792 & $-3,440$ & $-5,561$ & 12,499 & $-3,641$ & $-8,960$ & -143 & 0 & 0 & 0 & 0 & 0 & 0 \\
\hline Financing gap & 0 & 0 & 0 & 0 & 0 & 0 & 0 & 0 & 0 & 0 & 0 & 0 & 10,000 & 10,000 & 20,000 \\
\hline \multicolumn{16}{|l|}{ lemorandum items: } \\
\hline Nominal GDP & $1,600,169$ & $1,964,627$ & $2,310,767$ & $2,894,123$ & $2,894,123$ & $2,894,123$ & $2,894,123$ & $2,894,123$ & $2,894,123$ & $3,350,023$ & $3,350,023$ & $3,350,023$ & $3,350,023$ & $3,350,023$ & $3,350,023$ \\
\hline Total HIPC Initiative interim assistance & 0.0 & 75,326 & 106,617 & 41,516 & 17,861 & 8,236 & 86,497 & 91,891 & 93,650 & 80,671 & $\ldots$ & $\ldots$ & $\ldots$ & $\ldots$ & 62,865 \\
\hline Total HIPC Initiative interim assistance (as percent of GDP) & 0.0 & 3.8 & 4.6 & 1.4 & 0.6 & 0.3 & 3.0 & 3.2 & 3.2 & 2.4 & $\ldots$ & $\ldots$ & $\ldots$ & $\ldots$ & 1.9 \\
\hline \multirow{3}{*}{$\begin{array}{l}\text { Total poverty expenditures (percent of tot. expenditures) } \\
\text { (in millions of leones) }\end{array}$} & 15.4 & 21.4 & 22.5 & 15.5 & & & & 18.3 & 18.8 & 17.3 & 15.3 & 17.9 & 21.1 & 19.3 & 18.5 \\
\hline & 72,833 & 120,555 & 140,158 & 29,048 & 39,118 & 38,157 & 28,367 & 150,522 & 134,691 & 166,270 & 32,031 & 39,519 & 51,492 & 44,429 & 167,471 \\
\hline & \multicolumn{15}{|c|}{ (In percent of GDP, unless otherwise indicated) } \\
\hline Domestic revenue & 13.0 & 12.1 & 12.4 & 2.8 & 3.3 & 3.1 & 3.2 & 12.0 & 12.3 & 13.0 & 2.8 & 3.5 & 3.3 & 3.4 & 13.0 \\
\hline Total expenditure and net lending & 29.5 & 28.6 & 26.9 & 6.4 & 6.1 & 6.7 & 5.6 & 28.4 & 24.8 & 28.6 & 6.2 & 6.6 & 7.3 & 6.9 & 27.0 \\
\hline Of which: recurrent expenditure & 24.8 & 24.2 & 22.1 & 5.0 & 4.9 & 5.5 & 4.7 & 19.6 & 20.2 & 18.6 & 4.4 & 4.5 & 5.4 & 4.9 & 19.1 \\
\hline Of which: domestic interest expenditure & 2.8 & 2.6 & 2.8 & 0.7 & 0.8 & 1.2 & 0.9 & 3.4 & 3.6 & 2.8 & 0.8 & 0.7 & 0.7 & 0.6 & 2.8 \\
\hline \multicolumn{16}{|l|}{ Overall fiscal balance (commitment basis) } \\
\hline Including grants & -10.6 & $-8.3<$ & -6.7 & -1.4 & -1.6 & -2.3 & 1.7 & -7.4 & -3.5 & -5.4 & -1.6 & -1.0 & -2.1 & -0.1 & -4.6 \\
\hline Excluding grants & -16.5 & -16.5 & -14.5 & -3.7 & -2.8 & -3.6 & -2.4 & -16.4 & -12.5 & -15.6 & -3.4 & -3.1 & -4.0 & -3.5 & -14.0 \\
\hline Domestic primary balance $5 /$ & -7.7 & -7.0 & -5.6 & -0.9 & -0.9 & -0.7 & -0.4 & -2.8 & -2.8 & -1.8 & -0.4 & -0.3 & -0.9 & -0.6 & -2.3 \\
\hline (in millions of leones) & $-123,442$ & $-137,876$ & $-129,117$ & $-25,445$ & $-25,807$ & $-19,975$ & $-12,834$ & $-81,361$ & $-84,061$ & $-60,483$ & $-13,259$ & $-11,702$ & $-31,611$ & $-21,307$ & $-77,878$ \\
\hline Domestic financing & 3.2 & 0.9 & 4.3 & 0.9 & 1.0 & 1.0 & -3.1 & 1.5 & -0.1 & 1.0 & 1.1 & 0.4 & 0.0 & -0.7 & 0.9 \\
\hline Domestic debt stock & 50.2 & 44.8 & 40.9 & $\ldots$ & $\ldots$ & $\ldots$ & & 34.1 & 32.6 & $\ldots$ & $\ldots$ & $\ldots$ & $\ldots$ & $\ldots$ & 30.4 \\
\hline Total wages and salaries & 7.0 & 7.3 & 6.9 & 1.5 & 1.5 & 1.4 & 1.8 & 6.0 & 6.1 & 5.8 & 1.4 & 1.7 & 1.7 & 1.8 & 6.7 \\
\hline Total wages and salaries (percent of dom. revenue) & 53.9 & 59.8 & 55.7 & 53.2 & 45.8 & 43.5 & 56.5 & 49.9 & 49.7 & 44.6 & 51.7 & 48.4 & 51.2 & 53.9 & 51.3 \\
\hline
\end{tabular}

1/ Includes the disarmament, demobilization, and reintegration (DDR) program, which is managed outside the budget by a private firm hired by the DDR donors.

2/ To enhance transparency, actual debt-service payments in 2002 and projections beyond refer to debt service due before debt relief, and debt relief obtained is shown separately as a financing item.

Cologne flow rescheduling for $2002-04$ agreed by the Paris Club at the decision point in February 2002, and comparable relief by other creditors. Interim HIPC Initiative assistance by multilateral creditors is shown as grants.
Cont

th

5. Deserestion in the balance of payments from 2002 onward. In the 2002 program, HIPC Initiative relief was presented as extern

6/ See IMF Country Report No. 05/23. 
Table 3. Sierra Leone: Monetary Survey, December 2001-December 2005

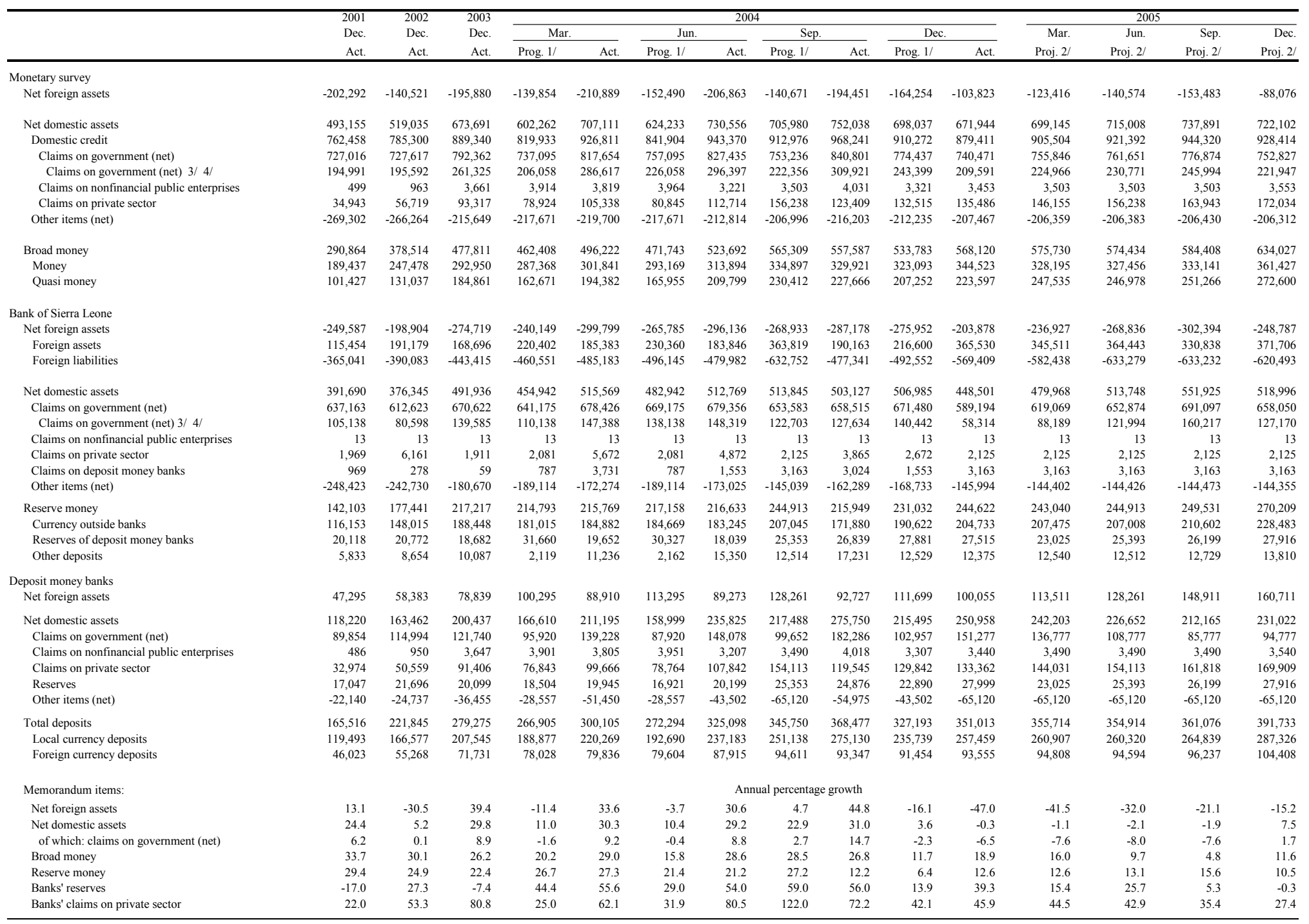

Sources: Sierra Leonean authorities; and IMF staff estimates and projection.

$1 /$ Items denominated in foreign currencies are valued at the program exchange rate of Le 2,600 per US\$1 (as specified in the TMU of January 2004),

2/ flems denominated in foreign currencies are valued at he program exchange rate of Le 2,950 per USS

torign exchange valuation losses incurred.

4/ Excluding non-interest-bearing stock. 
Table 4. Sierra Leone: Balance of Payments, 2001-10

(In millions of U.S. dollars, unless otherwise indicated)

\begin{tabular}{|c|c|c|c|c|c|c|c|c|c|c|c|}
\hline & $\begin{array}{r}2001 \\
\text { Act. }\end{array}$ & $\begin{array}{r}2002 \\
\text { Act. 1/ } \\
\end{array}$ & $\begin{array}{r}2003 \\
\text { Est. } \\
\end{array}$ & $\begin{array}{l}2004 \\
\text { Prog. }\end{array}$ & $\begin{array}{r}2004 \\
\text { Est. } \\
\end{array}$ & $\begin{array}{l}2005 \\
\text { Proj. }\end{array}$ & $\begin{array}{l}2006 \\
\text { Proj. }\end{array}$ & $\begin{array}{l}2007 \\
\text { Proj. }\end{array}$ & $\begin{array}{l}2008 \\
\text { Proj. }\end{array}$ & $\begin{array}{l}2009 \\
\text { Proj. }\end{array}$ & $\begin{array}{l}2010 \\
\text { Proj. }\end{array}$ \\
\hline Current account balance & -130.7 & -44.6 & -75.1 & -120.4 & -51.2 & -93.0 & -78.1 & -66.5 & -60.6 & -59.2 & -58.1 \\
\hline Balance on goods & -88.0 & -140.1 & -148.5 & -177.2 & -94.4 & -109.3 & -79.1 & -71.7 & -58.4 & -52.4 & -40.8 \\
\hline Exports, f.o.b. & 77.1 & 114.8 & 146.3 & 184.6 & 171.8 & 203.6 & 272.4 & 313.7 & 354.2 & 380.0 & 405.5 \\
\hline Of which: rutıle & 0.0 & 0.0 & 0.0 & 0.0 & 0.0 & 0.0 & 39.3 & 67.1 & 95.0 & 109.5 & 127.4 \\
\hline Of which: diamonds $2 /$ & 74.3 & 96.7 & 126.2 & 162.3 & 158.3 & 178.7 & 182.3 & 190.5 & 196.6 & 202.6 & 204.0 \\
\hline Of which: Kımberlıte & 0.0 & 0.0 & 0.0 & 19.0 & 17.3 & 23.0 & 37.0 & 43.0 & 43.0 & 43.0 & 43.0 \\
\hline Imports, f.o.b. & -165.1 & -254.9 & -294.8 & -361.8 & -266.2 & -312.9 & -351.5 & -385.5 & -412.6 & -432.4 & -446.2 \\
\hline Of which: petroleum products & -37.3 & -44.5 & -66.6 & -82.3 & -87.1 & -113.8 & -127.3 & -141.0 & -150.7 & -158.2 & -163.0 \\
\hline Of which: rice & -20.3 & -23.4 & -23.2 & -24.6 & -25.0 & -22.1 & -19.5 & -19.6 & -19.8 & -20.0 & -20.2 \\
\hline Balance on services & -58.9 & -42.4 & -62.6 & -65.2 & -79.8 & -89.7 & -94.8 & -99.3 & -103.0 & -108.6 & -114.5 \\
\hline Credit & 52.0 & 38.3 & 51.0 & 53.8 & 74.5 & 79.4 & 85.4 & 94.4 & 103.3 & 113.1 & 123.9 \\
\hline Debit & -110.9 & -80.8 & -113.6 & -119.0 & -154.4 & -169.0 & -180.2 & -193.7 & -206.3 & -221.8 & -238.4 \\
\hline Income & -25.3 & -29.2 & -27.0 & -27.6 & -27.6 & -30.3 & -33.7 & -31.7 & -32.3 & -33.2 & -33.5 \\
\hline Credit & 4.3 & 18.3 & 19.8 & 20.3 & 20.3 & 20.7 & 21.2 & 21.7 & 22.2 & 22.7 & 23.2 \\
\hline Debit & -29.6 & -47.5 & -46.9 & -47.9 & -47.8 & -51.0 & -54.9 & -53.4 & -54.4 & -55.9 & -56.7 \\
\hline Interest payments due before debt relief 3 / & -14.8 & -26.3 & -22.8 & -21.5 & -21.4 & -22.7 & -25.8 & -23.7 & -22.9 & -22.7 & -22.0 \\
\hline Current transfers & 41.5 & 167.2 & 163.0 & 149.7 & 150.7 & 136.3 & 129.5 & 136.3 & 133.0 & 135.0 & 130.6 \\
\hline Public (net) $4 /$ & 34.3 & 69.0 & 64.7 & 64.9 & 71.2 & 58.3 & 51.0 & 57.3 & 53.2 & 54.2 & 48.5 \\
\hline Of which: HIPC Initiative grants & & 35.8 & 45.4 & 35.0 & 34.8 & 21.3 & 24.1 & 30.6 & 29.8 & 29.5 & 30.0 \\
\hline Private (net) $5 /$ & 7.2 & 98.2 & 98.4 & 84.8 & 79.5 & 77.9 & 78.5 & 78.9 & 79.7 & 80.7 & 81.9 \\
\hline Current account balance, excl. public transfers & -165.0 & -113.6 & -139.7 & -185.2 & -122.3 & -151.3 & -129.1 & -123.7 & -113.9 & -113.4 & -106.6 \\
\hline Capital and financial account & 143.5 & 41.7 & 29.7 & 93.1 & 66.4 & 25.8 & 23.7 & 34.3 & 23.9 & 21.4 & 13.4 \\
\hline Capital account & 6.9 & 7.6 & 16.4 & 28.2 & 22.1 & 37.8 & 37.9 & 38.0 & 38.1 & 38.2 & 38.3 \\
\hline Project grants & 6.6 & 5.5 & 14.2 & 26.1 & 19.9 & 35.6 & 35.6 & 35.6 & 35.6 & 35.6 & 35.6 \\
\hline Private capital transfers & 0.2 & 2.1 & 2.2 & 2.2 & 2.2 & 2.3 & 2.4 & 2.5 & 2.6 & 2.7 & 2.8 \\
\hline Financial account & 136.6 & 34.1 & 13.3 & 64.9 & 44.3 & -12.0 & -14.3 & -3.7 & -14.2 & -16.8 & -24.9 \\
\hline Direct investment and portfolio investment 6/ & 9.8 & 1.7 & 21.0 & 29.5 & 12.5 & 27.2 & 7.2 & 2.2 & 2.2 & 4.6 & 6.0 \\
\hline Other investment & 126.8 & 32.4 & -7.7 & 35.4 & 31.8 & -39.2 & -21.4 & -5.9 & -16.4 & -21.4 & -30.9 \\
\hline Public sector loans (net) & 36.0 & 43.9 & 10.8 & 41.4 & 43.2 & 1.3 & 9.6 & 6.1 & 0.6 & -0.4 & -0.9 \\
\hline Of which: disbursements & 56.7 & 66.8 & 48.4 & 88.4 & 90.3 & 53.1 & 46.0 & 43.0 & 38.0 & 38.0 & 36.0 \\
\hline Of which: program loans & 33.8 & 40.9 & 15.9 & 29.5 & 31.3 & 10.1 & 5.0 & 5.0 & 5.0 & 5.0 & 5.0 \\
\hline Of which: amortization due before debt reliet $7 /$ & -20.8 & -22.9 & -37.5 & -47.0 & -47.0 & -51.8 & -36.4 & -36.9 & -37.4 & -38.4 & -36.9 \\
\hline Private sector loans (net) $8 /$ & -22.0 & 0.0 & 0.0 & 26.4 & 38.4 & 5.6 & -4.0 & 11.0 & 5.0 & 0.0 & -10.0 \\
\hline Change in net foreign assets of commercial banks & -3.4 & -5.3 & -8.7 & -17.4 & -7.8 & -20.6 & -14.0 & -11.0 & -11.0 & -11.0 & -11.0 \\
\hline Other, including errors and omissions & 116.2 & -6.2 & -9.8 & -15.0 & -42.0 & -25.5 & -13.0 & -12.0 & -11.0 & -10.0 & -9.0 \\
\hline Overall balance & 12.8 & -2.9 & -45.4 & -27.2 & 15.3 & -67.2 & -54.4 & -32.1 & -36.7 & -37.7 & -44.7 \\
\hline Financing & -12.8 & 2.9 & 45.4 & 27.2 & -15.3 & 67.2 & 54.4 & 32.1 & 36.7 & 37.7 & 44.7 \\
\hline Change in net foreign assets of the central bank (- increase) & -29.6 & -27.7 & 10.2 & -4.9 & -47.4 & 14.6 & -24.7 & -36.7 & -45.6 & -49.6 & -56.0 \\
\hline Change in reserve assets (- increase) & -13.9 & -32.3 & 25.2 & -22.5 & -65.5 & 1.8 & -20.0 & -20.0 & -20.0 & -20.0 & -20.0 \\
\hline Net Fund credit & -15.8 & 4.6 & -15.1 & 17.6 & 18.1 & 12.8 & -4.7 & -16.7 & -25.6 & -29.6 & -36.0 \\
\hline Disbursements & 59.6 & 36.0 & 19.6 & 41.1 & 41.2 & 21.6 & 0.0 & 0.0 & 0.0 & 0.0 & 0.0 \\
\hline Repayments & -75.4 & -31.4 & -34.6 & -23.5 & -23.1 & -8.7 & -4.7 & -16.7 & -25.6 & -29.6 & -36.0 \\
\hline Exceptional financing & 16.8 & 30.6 & 35.2 & 32.1 & 32.1 & 34.9 & 35.5 & 35.1 & 35.3 & 36.5 & 33.8 \\
\hline Change in arrears $(+$ increase $) 9 /$ & -239.1 & 6.7 & -13.8 & -9.5 & -9.5 & 0.0 & 0.0 & 0.0 & 0.0 & 0.0 & 0.0 \\
\hline Debt relief $10 /$ & 255.9 & 23.9 & 49.1 & 41.6 & 41.6 & 34.9 & 35.5 & 35.1 & 35.3 & 36.5 & 33.8 \\
\hline Financing gap 11/ & 0.0 & 0.0 & 0.0 & 0.0 & 0.0 & -17.7 & -43.6 & -33.7 & -47.1 & -50.8 & -66.9 \\
\hline Memorandum items: & \multicolumn{11}{|c|}{ (In percent of GDP) } \\
\hline Current account & -17.4 & -4.8 & -7.6 & -11.5 & -4.9 & -8.0 & -6.2 & -4.8 & -4.1 & -3.7 & -3.4 \\
\hline Current account, excluding public transfers & -22.0 & -12.1 & -14.1 & -17.7 & -11.7 & -13.0 & -10.2 & -9.0 & -7.7 & -7.1 & -6.2 \\
\hline Overall balance of payments & 1.7 & -0.3 & -4.6 & -2.6 & 1.5 & -5.8 & -4.3 & -2.3 & -2.5 & -2.4 & -2.6 \\
\hline Exports, f.o.b. & 10.3 & 12.3 & 14.8 & 17.7 & 16.5 & 17.6 & 21.6 & 22.9 & 23.9 & 23.7 & 23.8 \\
\hline Imports, c.i.f. & 25.6 & 31.7 & 35.0 & 40.7 & 29.0 & 31.6 & 31.6 & 30.7 & 29.7 & 27.1 & 25.6 \\
\hline Gross ofticial reserves (in millions of U.S. dollars) & 51.9 & 84.6 & 59.4 & 81.9 & 124.9 & 123.1 & 143.1 & 163.1 & 183.1 & 203.1 & 223.1 \\
\hline Gross ofticial reserves (in months of imports) $12 /$ & 1.9 & 2.5 & 1.7 & 2.0 & 3.1 & 2.8 & 3.0 & 3.2 & 3.4 & 3.6 & 3.9 \\
\hline
\end{tabular}

Sources: Sierra Leonean authorities; and IMF staff estimates and projections.

1/ Balance of payments data for 2002 were compiled for the first time on the basis of the Balance of Payments Manual, fifth edition, which has led to

a number of significant changes, including a better measurement of nondutiable imports and private transfers through the use of new surveys.

2/ Includes unrecorded diamond exports estimated from partner-country data.

3/ Official interest payments due, including Fund charges.

4/ Includes mostly program grants.

5/ Includes worker remittances and transfers to nongovernment organizations.

6/ Includes investment related to the rehabilitation of the Koidu Kimberlite mine

and assumes investment in rutile mining, financed by foreign loans, foreign investment, and government on-lending of an EU grant.

7/ Amortization due increases in 2003 and beyond because of debt-service payments falling due on previously rescheduled arrears.

8/ Includes capital outflows associated with unrecorded diamond exports, change in trade credit, and errors and omissions.

9/ The arrears accumulation in 2002 is due to technical arrears that were accumulated while negotiations with bilateral creditors on rescheduling were not

yet concluded. The arrears reduction in 2003 results from the implementation of arrears rescheduling agreements with the EU, the Saudi Fund

for Economic Development, and the OPEC Fund. In 2004, arrears-clearance operations with the EU and the OPEC Fund are completed.

10/ This reflects the rescheduling on Cologne terms for the period 2002-04 agreed by the Paris Club at the decision point in February 2002, and

comparable relief by other creditors.

11/ The financing gap in 2005 could be closed with disbursements from the Fund under the present arrangement and a possible successor arrangement.

12/ In months of imports of total goods and services of subsequent year. 
(In millions of leones)

\begin{tabular}{|c|c|c|c|c|c|c|c|c|c|c|}
\hline & \multirow{2}{*}{$\begin{array}{l}2001 \\
\text { Act. }\end{array}$} & \multirow{2}{*}{$\begin{array}{l}2002 \\
\text { Act. }\end{array}$} & \multirow{2}{*}{$\begin{array}{l}2003 \\
\text { Act. }\end{array}$} & \multicolumn{5}{|c|}{2004} & \multicolumn{2}{|c|}{2005} \\
\hline & & & & $\begin{array}{l}\text { Quarter } 1 \\
\text { Act. }\end{array}$ & $\begin{array}{l}\text { Quarter } 2 \\
\text { Act. }\end{array}$ & $\begin{array}{c}\text { Quarter } 3 \\
\text { Act. }\end{array}$ & $\begin{array}{l}\text { Quarter } 4 \\
\text { Act. }\end{array}$ & $\begin{array}{l}\text { Full year } \\
\text { Act. }\end{array}$ & $\begin{array}{l}\text { Budget } \\
\text { Speech }\end{array}$ & Prop. \\
\hline Total poverty-targeted expenditure & $72,832.5$ & $120,555.1$ & $140,158.0$ & $29,048.5$ & $39,118.5$ & $38,156.8$ & $28,366.8$ & $134,690.6$ & $166,269.6$ & $167,470.9$ \\
\hline Recurrent poverty-targeted expenditure & $69,840.5$ & $108,193.4$ & $120,834.4$ & $27,799.8$ & $36,202.1$ & $35,932.2$ & $25,966.0$ & $125,900.1$ & $147,219.6$ & $148,770.9$ \\
\hline \multicolumn{11}{|l|}{ General services } \\
\hline Ministry of Local Government and Community Development & $\ldots$ & $\ldots$ & $\ldots$ & 180.8 & 305.4 & $1,057.6$ & 426.4 & $1,970.2$ & 845.3 & 845.3 \\
\hline Security services & $15,450.5$ & $15,272.2$ & $26,158.5$ & $8,582.4$ & $6,189.5$ & $7,000.2$ & $6,264.1$ & $28,036.2$ & $26,176.7$ & $25,176.7$ \\
\hline Police & $10,815.6$ & $10,278.9$ & $16,275.9$ & $4,288.5$ & $4,288.5$ & $4,390.0$ & $4,026.3$ & $16,993.3$ & $18,094.0$ & $17,094.0$ \\
\hline Prisons Department & $3,969.1$ & $4,588.6$ & $5,237.0$ & 876.5 & $1,695.7$ & $1,823.4$ & $2,150.1$ & $6,545.7$ & $6,699.6$ & $6,699.6$ \\
\hline National Fire Authority & 665.8 & 404.7 & $4,645.5$ & $3,417.4$ & 205.3 & 786.8 & 87.7 & $4,497.2$ & $1,383.1$ & $1,383.1$ \\
\hline Social services & $45,802.5$ & $73,955.6$ & $75,783.1$ & $14,389.0$ & $23,617.6$ & $22,603.1$ & $17,132.5$ & $77,742.2$ & $81,795.6$ & $68,251.9$ \\
\hline Ministry of Education, Science and Technology & $29,014.9$ & $44,096.8$ & $43,089.9$ & $11,438.1$ & $16,778.9$ & $12,129.5$ & $9,608.3$ & $49,954.8$ & $50,162.3$ & $41,980.5$ \\
\hline Ministry of Health and Sanitation & $15,573.9$ & $27,366.4$ & $29,962.0$ & $1,420.5$ & $5,599.1$ & $9,410.2$ & $5,040.4$ & $21,470.2$ & $25,603.1$ & $22,188.6$ \\
\hline Ministry of Social Welfare, Gender and Children's Affairs (Social Welfare Division) & 811.5 & 886.5 & $1,097.0$ & 284.3 & 306.4 & 156.6 & 309.3 & $1,056.6$ & $1,194.9$ & $1,019.7$ \\
\hline Gender and Children's Affairs Division & 402.2 & $1,605.9$ & $1,634.2$ & 482.5 & 281.6 & 343.6 & 291.3 & $1,399.0$ & $1,060.3$ & 904.9 \\
\hline Ministry of Youth and Sports & $\ldots$ & $\ldots$ & $\ldots$ & 632.5 & 583.2 & 563.2 & 337.5 & $2,116.4$ & $1,552.0$ & $1,324.5$ \\
\hline Socially-oriented projects & $\ldots$ & $\ldots$ & $\ldots$ & 131.1 & 68.4 & 0.0 & $1,545.7$ & $1,745.2$ & $2,223.0$ & 833.8 \\
\hline Economic services & $8,587.5$ & $18,965.6$ & $18,892.8$ & $4,647.6$ & $6,089.6$ & $5,271.3$ & $2,143.0$ & $18,151.5$ & $20,407.6$ & $17,502.7$ \\
\hline Ministry of Agriculture and Food Security & $1,988.5$ & $4,230.5$ & $8,835.7$ & $2,807.5$ & $4,845.2$ & $2,323.3$ & $1,326.8$ & $11,302.8$ & $14,539.9$ & $12,470.2$ \\
\hline Ministry of Transport and Communications & $3,880.0$ & $3,252.0$ & $2,182.6$ & 890.6 & 228.0 & 711.2 & 133.7 & $1,963.5$ & $1,196.3$ & $1,026.0$ \\
\hline Ministry of Energy and Power & $2,719.0$ & $2,929.4$ & $3,602.7$ & 949.5 & $1,016.4$ & 11.9 & 642.5 & $2,620.3$ & $3,671.4$ & $3,148.8$ \\
\hline Domestic debt payback program & & $8,553.7$ & $4,271.9$ & 0.0 & 0.0 & 2,224.9 & 40.0 & 2,264.9 & $1,000.0$ & 857.7 \\
\hline Transfers to local councils & $\ldots$ & $\ldots$ & $\ldots$ & $\ldots$ & $\ldots$ & $\ldots$ & $\ldots$ & $\ldots$ & $17,994.4$ & $16,994.4$ \\
\hline Unallocated recurrent poverty-related outlays & $\ldots$ & $\ldots$ & & $\ldots$ & & $\ldots$ & $\ldots$ & $\ldots$ & & $20,000.0$ \\
\hline Development poverty-targeted expenditure & $2,992.0$ & $12,361.7$ & $19,323.6$ & $1,248.7$ & $2,916.4$ & 2,224.6 & $2,400.8$ & $8,790.5$ & $19,050.0$ & $18,700.0$ \\
\hline General services & $2,442.0$ & $2,379.5$ & $1,076.9$ & 160.5 & 463.7 & 757.5 & 97.3 & $1,479.0$ & 200.0 & 100.0 \\
\hline Ministry of Rural Development and Local Government & $2,442.0$ & $2,379.5$ & $1,076.9$ & 135.5 & 418.7 & 732.5 & 72.3 & $1,359.0$ & 0.0 & 0.0 \\
\hline Office of the President & $\ldots$ & $\ldots$ & $\ldots$ & 25.0 & 45.0 & 25.0 & 25.0 & 120.0 & 200.0 & 100.0 \\
\hline Security services & & & $1,038.7$ & 0.0 & 0.0 & 100.0 & 0.0 & 100.0 & 200.0 & 50.0 \\
\hline Prison Department & $\ldots$ & 179.8 & 914.7 & 0.0 & 0.0 & 100.0 & 0.0 & 100.0 & 200.0 & 50.0 \\
\hline Fire Force Authority & $\ldots$ & $\ldots$ & 124.0 & 0.0 & 0.0 & 0.0 & 0.0 & 0.0 & 0.0 & 0.0 \\
\hline Social services & 550.0 & $3,947.5$ & $9,267.4$ & 438.8 & 612.5 & 538.4 & 346.0 & $1,935.7$ & $4,370.0$ & $4,270.0$ \\
\hline Ministry of Education, Youth and Sport & 350.0 & $3,688.7$ & $4,558.1$ & 55.0 & 362.5 & 170.0 & 10.0 & 597.5 & $1,200.0$ & $1,100.0$ \\
\hline Ministry of Health and Sanitation & 0.0 & 162.8 & $4,393.3$ & 0.0 & 150.0 & 179.6 & 172.0 & 501.6 & 480.0 & 480.0 \\
\hline Ministry of Social Welfare, Gender and Children Affairs & 200.0 & 96.0 & 316.0 & 0.0 & 0.0 & 50.0 & 0.0 & 50.0 & 100.0 & 100.0 \\
\hline National Commission for Social Action (NaCSA) & $\ldots$ & $\ldots$ & $\ldots$ & 383.8 & 100.0 & 138.8 & 164.0 & 786.6 & $2,590.0$ & $2,590.0$ \\
\hline Economic services & $\ldots$ & $6,034.7$ & $7,940.7$ & 649.4 & $1,840.2$ & 828.7 & $1,957.5$ & $5,275.8$ & $13,280.0$ & $13,280.0$ \\
\hline Ministry of Agriculture and Food Security & $\cdots$ & $2,788.0$ & $2,190.1$ & 0.0 & 0.0 & 43.7 & 12.5 & 56.2 & 830.0 & 830.0 \\
\hline Ministry of Marine Resources & $\ldots$ & 449.7 & 970.5 & 49.4 & 75.2 & 50.0 & 0.0 & 174.6 & 250.0 & 250.0 \\
\hline Ministry of Energy and Power & $\ldots$ & & 272.9 & 0.0 & 0.0 & 300.0 & 0.0 & 300.0 & $2,000.0$ & $2,000.0$ \\
\hline Ministry of Works, Housing and Technical Maintenance & $\ldots$ & $2,797.0$ & $4,507.1$ & 600.0 & $1,765.0$ & 435.0 & $1,945.0$ & $4,745.0$ & $10,200.0$ & $10,200.0$ \\
\hline Local government development grants & $\ldots$ & $\ldots$ & ... & $\ldots$ & $\ldots$ & $\ldots$ & $\ldots$ & $\ldots$ & $1,000.0$ & $1,000.0$ \\
\hline
\end{tabular}

Source: Sierra Leone, Ministry of Finance, Budget Bureau. 
Table 6. Sierra Leone: External Financing Requirements and Sources, 2002-10 (In millions of U.S. dollars)

\begin{tabular}{|c|c|c|c|c|c|c|c|c|c|}
\hline & $\begin{array}{r}2002 \\
\text { Est. }\end{array}$ & $\begin{array}{r}2003 \\
\text { Est. }\end{array}$ & $\begin{array}{r}2004 \\
\text { Est. }\end{array}$ & $\begin{array}{l}2005 \\
\text { Proj. }\end{array}$ & $\begin{array}{l}2006 \\
\text { Proj. }\end{array}$ & $\begin{array}{l}2007 \\
\text { Proj. }\end{array}$ & $\begin{array}{l}2008 \\
\text { Proj. }\end{array}$ & $\begin{array}{l}2009 \\
\text { Proj. }\end{array}$ & $\begin{array}{l}2010 \\
\text { Proj. }\end{array}$ \\
\hline $\begin{array}{l}\text { Current account } \\
\text { (excluding interest and official transfers) }\end{array}$ & -87.2 & -116.9 & -100.9 & -128.6 & -103.3 & -100.0 & -91.0 & -90.7 & -84.6 \\
\hline Debt-service obligations (before relief) & 80.7 & 94.9 & 91.6 & 83.2 & 66.9 & 77.3 & 85.9 & 90.7 & 95.0 \\
\hline Interest & 26.3 & 22.8 & 21.4 & 22.7 & 25.8 & 23.7 & 22.9 & 22.7 & 22.0 \\
\hline Amortization & 54.3 & 72.1 & 70.2 & 60.5 & 41.1 & 53.5 & 63.0 & 68.0 & 73.0 \\
\hline Bilateral & 31.8 & 34.5 & 38.0 & 42.0 & 35.1 & 35.5 & 35.4 & 35.6 & 32.6 \\
\hline Multilateral & 44.7 & 54.2 & 48.7 & 37.2 & 28.5 & 40.1 & 49.2 & 53.3 & 60.5 \\
\hline IMF & 32.2 & 35.5 & 24.0 & 9.7 & 5.7 & 17.6 & 26.1 & 30.3 & 36.6 \\
\hline Reduction of arrears 1/ & -6.7 & 13.8 & 9.5 & 0.0 & 0.0 & 0.0 & 0.0 & 0.0 & 0.0 \\
\hline Increase in gross reserves & 32.3 & -25.2 & 65.5 & -1.8 & 20.0 & 20.0 & 20.0 & 20.0 & 20.0 \\
\hline Gross financing requirement & -193.5 & -200.5 & -267.5 & -210.0 & -190.2 & -197.3 & -196.9 & -201.4 & -199.6 \\
\hline Identified disbursements & 193.5 & 200.5 & 267.5 & 192.4 & 146.6 & 163.6 & 149.8 & 150.6 & 132.7 \\
\hline Loans for balance of payments support & 76.9 & 35.4 & 72.5 & 31.7 & 5.0 & 5.0 & 5.0 & 5.0 & 5.0 \\
\hline IMF & 36.0 & 19.6 & 41.2 & 21.6 & 0.0 & 0.0 & 0.0 & 0.0 & 0.0 \\
\hline World Bank/IDA & 28.5 & 15.9 & 16.9 & 0.0 & 0.0 & 0.0 & 0.0 & 0.0 & 0.0 \\
\hline African Development Bank & 12.3 & 0.0 & 14.5 & 10.1 & 5.0 & 5.0 & 5.0 & 5.0 & 5.0 \\
\hline Grants & 76.9 & 81.3 & 99.8 & 96.6 & 89.4 & 95.8 & 91.9 & 93.1 & 87.5 \\
\hline Program & 56.2 & 61.6 & 73.7 & 61.0 & 53.8 & 60.2 & 56.3 & 57.5 & 52.0 \\
\hline Of which: HIPC Initiative grants & 35.8 & 45.4 & 35.0 & 21.3 & 24.1 & 30.6 & 29.8 & 29.5 & 30.0 \\
\hline Project & 20.8 & 19.7 & 26.1 & 35.6 & 35.6 & 35.6 & 35.6 & 35.6 & 35.6 \\
\hline Project loans & 25.9 & 32.5 & 58.9 & 43.0 & 41.0 & 38.0 & 33.0 & 33.0 & 31.0 \\
\hline Foreign direct investment and private sector loans & 1.6 & 21.0 & 50.9 & 32.8 & 3.2 & 13.2 & 7.2 & 4.6 & -4.0 \\
\hline Debt relief 2/ & 23.9 & 49.1 & 41.6 & 34.9 & 35.5 & 35.1 & 35.3 & 36.5 & 33.8 \\
\hline Other capital, including errors and omissions & -11.7 & -18.8 & -56.4 & -46.5 & -27.4 & -23.5 & -22.5 & -21.6 & -20.6 \\
\hline Financing gap 4/ & 0.0 & 0.0 & 0.0 & -17.7 & -43.6 & -33.7 & -47.1 & -50.8 & -66.9 \\
\hline
\end{tabular}

Sources: Sierra Leonean authorities; and IMF staff estimates and projections.

1/ Rescheduling of arrears by the Paris Club; assumes comparable treatment by other creditors, including military contractors.

2/ Include Naples flow rescheduling provided by the Paris Club in October 2001 and additional relief by other creditors,

Cologne flow rescheduling for 2002-04 agreed by the Paris Club at the decision point in February 2002, and

comparable relief by other creditors. For 2001, the amount includes the rescheduling of arrears of $\$ 239.1$ million.

3 / Includes capital outflows associated with unrecorded diamond exports, change in trade credit,

and errors and omissions.

4/ After identified disbursements, debt reschedulings, HIPC Initiative assistance, and short-term capital movements.

The financing gap in 2005 could be closed with disbursements from the Fund under the present arrangement and a possible successor arrangement. 
Table 7. Sierra Leone: Indicators of Capacity to Repay the Fund, 2001-10 1/

(In millions of U.S. dollars, unless otherwise indicated)

\begin{tabular}{|c|c|c|c|c|c|c|c|c|c|c|}
\hline & 2001 & 2002 & 2003 & $\begin{array}{c}2004 \\
\text { Est. }\end{array}$ & $\begin{array}{l}2005 \\
\text { Proj. }\end{array}$ & $\begin{array}{l}2006 \\
\text { Proj. }\end{array}$ & $\begin{array}{l}2007 \\
\text { Proj. }\end{array}$ & $\begin{array}{l}2008 \\
\text { Proj. }\end{array}$ & $\begin{array}{l}2009 \\
\text { Proj. }\end{array}$ & $\begin{array}{l}2010 \\
\text { Proj. }\end{array}$ \\
\hline \multicolumn{11}{|l|}{ Fund credit outstanding (end of period) $1 /$} \\
\hline In millions of SDRs & 120.8 & 124.5 & 113.8 & 126.0 & 134.4 & 131.3 & 120.5 & 103.9 & 84.7 & 61.4 \\
\hline In millions of U.S. dollars & 153.8 & 161.3 & 159.1 & 185.4 & 207.0 & 202.4 & 185.9 & 160.3 & 130.7 & 94.6 \\
\hline \multirow[t]{2}{*}{ In percent of quota } & 116.5 & 120.1 & 109.7 & 121.6 & 129.6 & 126.7 & 116.2 & 100.2 & 81.7 & 59.2 \\
\hline & \multicolumn{9}{|c|}{ In millions of US dollars } & \\
\hline Fund obligations & 78.1 & 32.2 & 35.5 & 24.0 & 9.8 & 5.7 & 17.6 & 26.1 & 30.3 & 36.6 \\
\hline Fund total charges and interests & 2.7 & 0.8 & 0.9 & 0.9 & 1.1 & 1.0 & 1.0 & 0.5 & 0.7 & 0.6 \\
\hline Existing drawings & 2.7 & 0.8 & 0.9 & 0.9 & 1.0 & 0.9 & 0.9 & 0.4 & 0.6 & 0.5 \\
\hline Prospective drawings & 0.0 & 0.0 & 0.0 & 0.0 & 0.1 & 0.1 & 0.1 & 0.1 & 0.1 & 0.1 \\
\hline Fund total repayments/repurchases & 75.4 & 31.4 & 34.6 & 23.1 & 8.7 & 4.7 & 16.7 & 25.6 & 29.6 & 36.0 \\
\hline Existing drawings & 75.4 & 31.4 & 34.6 & 23.1 & 8.7 & 4.7 & 16.7 & 25.6 & 29.6 & 36.0 \\
\hline Prospective drawings & 0.0 & 0.0 & 0.0 & 0.0 & 0.0 & 0.0 & 0.0 & 0.0 & 0.0 & 0.0 \\
\hline \multicolumn{11}{|l|}{ Fund credit outstanding } \\
\hline In percent of exports of goods and services & 119.1 & 105.3 & 80.6 & 75.3 & 73.2 & 56.6 & 45.6 & 35.0 & 26.5 & 17.9 \\
\hline In percent of total external debt $2 /$ & 59.6 & 46.0 & 39.0 & 35.7 & 33.5 & 29.0 & 23.7 & 18.4 & 13.9 & 9.5 \\
\hline In percent of gross official reserves & 296.6 & 190.6 & 267.9 & 148.5 & 168.2 & 141.5 & 114.0 & 87.5 & 64.3 & 42.4 \\
\hline \multicolumn{11}{|l|}{ Fund obligations } \\
\hline In percent of exports of goods and services & 60.5 & 21.0 & 18.0 & 9.7 & 3.5 & 1.6 & 4.3 & 5.7 & 6.1 & 6.9 \\
\hline In percent of external debt service $2 /$ & 70.4 & 39.9 & 37.4 & 26.2 & 11.8 & 8.6 & 22.8 & 30.4 & 33.4 & 38.5 \\
\hline In percent of gross international reserves & 150.6 & 38.1 & 59.8 & 19.2 & 7.9 & 4.0 & 10.8 & 14.3 & 14.9 & 16.4 \\
\hline \multicolumn{11}{|l|}{ Memorandum items: } \\
\hline Exports of goods and services (in millions of U.S. dollars) & 129.1 & 153.2 & 197.3 & 246.3 & 283.0 & 357.8 & 408.1 & 457.5 & 493.2 & 529.4 \\
\hline Gross official reserves (in months of imports of goods and services) & 1.9 & 2.5 & 1.7 & 3.1 & 2.8 & 3.0 & 3.2 & 3.4 & 3.6 & 3.9 \\
\hline
\end{tabular}

Sources: Sierra Leonean authorities; and IMF staff estimates and projections.

1/ All numbers are before HIPC Initiative assistance.

2/ Before rescheduling. 
Table 8. Sierra Leone: Disbursements Under the PRGF Arrangement, 2001-05 (In millions of SDRs)

\begin{tabular}{|c|c|c|}
\hline Date & Disbursement & Subject to: \\
\hline September 2001 & $46.84^{1}$ & Approval of arrangement \\
\hline March 2002 & 9.33 & $\begin{array}{l}\text { First review and performance criteria } \\
\text { (PCs) for end-September } 2001\end{array}$ \\
\hline September 2002 & 18.66 & $\begin{array}{l}\text { Second review and PCs for end- } \\
\text { December } 2001 \text { and PCs for end- } \\
\text { March } 2002\end{array}$ \\
\hline March 2003 & 14.00 & $\begin{array}{l}\text { Third review and PCs for end- } \\
\text { September } 2002 \text { and PCs for end- } \\
\text { December } 2002\end{array}$ \\
\hline February 2004 & 14.00 & $\begin{array}{l}\text { Fourth review and PCs for end-June } \\
2003\end{array}$ \\
\hline November 2004 & 14.00 & $\begin{array}{l}\text { Fifth review and PCs for end-March } \\
2004\end{array}$ \\
\hline May 2005 & 14.00 & $\begin{array}{l}\text { Sixth review and PCs for end- } \\
\text { December } 2004\end{array}$ \\
\hline
\end{tabular}

Source: IMF

${ }^{1}$ Of this total, an amount equivalent to SDR 37.51 million (36.17 percent of quota) was disbursed and used to replace an equivalent amount outstanding in purchases under the emergency post-conflict assistance policy. 
Table 9. Sierra Leone: Status of HIPC Initiative Completion Point Triggers (Status as of February 2005)

\section{Triggers}

PRSP. Preparation of a full PRSP and implementation for at least one year, as evidenced by the satisfactory joint staff assessment of the PRSP and the country's annual progress report.

Macroeconomic stability. Continued maintenance of macroeconomic stability, as evidenced by satisfactory implementation of the PRGF-supported program.

Use of budgetary savings. The budgetary savings from interim debt-service relief in 2002 have been used in the priority areas indicated in Table 2 of the Enhanced Initiative for Heavily Indebted Poor Countries-Decision Point, February 15, 2002 (www.imf.org) and monitored in the framework for poverty-reduction expenditures. The increase in total spending on these priorities will be proportionate to HIPC Initiative relief. Budgetary savings from interim debt-service relief in subsequent years will be used in accordance with the agreed annual budgets for those years.

\section{Governance and decentralization of government functions} Completion of disarmament, demobilization, and provision of reintegration assistance to all former combatants under the DDR program.

Biannual tracking of public expenditures on priority areas within the PETS framework, including development expenditures, dissemination, and publication of results.

Adoption and implementation of the MTEF, and budget system for tracking expenditures at the regional levels.

\section{Structural measures}

Bill has been passed to introduce new privatization legislation that establishes the independent National Privatization Commission to implement the government's divesture strategy, which was approved by the cabinet in May 2000 .

Adoption by the government of a revised mining policy to promote formal activity (including artisanal mining) and attract private investment for medium- and large-scale mining.

\section{Education}

The primary gross enrollment rates for girls will have been increased to at least 65 percent.

\section{Status}

The Final PRSP has been submitted to the staffs of the Fund and the World Bank for their review.

The outcome of the fifth review of the PRGF arrangement with the IMF on November 12, 2004, and the release of US\$21.1 million to the government indicated satisfactory performance under the program and continued maintenance of macroeconomic stability. An IMF mission conducted the sixth review of the PRGF in February 2005.

Interim HIPC Initiative debt relief for 2004 was Le 174.4 billion, up from Le140.6 billion in 2003 plus a carryover from 2002 of Le 35.8 billion. Due to expenditure cuts to meet fiscal targets in line with macroeconomic objectives, actual spending in 2004 amounted to Le 135.1 billion. Substantial increases in expenditures on poverty reducing activities on education and agriculture including health were made. In proportion with HIPC relief funds release, poverty expenditure is projected at Le 147.5 billion in 2005 .

The Executive Secretariat of NCDDR was closed to the public on March 31, 2004. A one-off payment to a residual caseload of 3,600 eligible former combatants who did not participate in reintegration activities has been concluded. Region/district offices of NCDDR have been closed, and the report of a final external evaluation is now available.

The PETS for FY 2003 expenditures covering the distribution of seed rice in the Ministry of Agriculture, Forestry, and Food Security, essential drugs in the Ministry of Health, and school furniture in the Ministry of Education was conducted in August/September 2004; an analysis of field data is in progress.

Following the devolution of functions to local councils, budgetary provisions are being provided separately to be supervised by a local government finance committee. A new Chart of Accounts containing a segment to capture expenditures up to district, chiefdom, and ward levels has been developed for introduction in FY 2005. Effective introduction will take place when the IFMIS computerized system becomes operational in May 2005.

The NCP completed its divestiture plan in September 2003 and issued a revised plan in December 2004. Additional preparatory work is being carried out to ensure clear and transparent procedures for the sale, transfer, or disposal of government shares. Several state-owned entities have been earmarked for privatization in 2005 .

The Ministry of Mineral Resources in collaboration with DfID and the World Bank has prepared implementation plans for pilot activities in the mining cadastre system and the provision of extension services in Kono. This will aim at boosting private sector led investment in the mineral sector and promote artisanal mining for self-employment and job creation.

Primary school enrollment continues to increase. The enrollment rate is reported to increase from 967,000 pupils in school year 2002/03 to $1,100,000$ pupils in the school year 2003/04, an increase of 14 percent. Most of the enrollment growth has been concentrated in classes 1-3. The female enrollment rates in primary school stands at 42 percent, 
which gives a girls/boys ratio of 71 percent.

Table 9. Sierra Leone: Status of HIPC Initiative Completion Point Triggers (Status as of February 2005) (Concluded)

\section{Triggers}

At least 1,500 unqualified teachers will have received formal inservice training in primary schools, and at least 500 unqualified teachers will have received in-service training in secondary schools.

\section{Health}

Distribution of insecticide-treated bed nets will have increased from 18,482 in 2000 to 60,000 .

At least 200 persons, professionals and staff from line ministries and health and civil society organizations, will have been provided by the National HIV/AIDS Secretariat with HIV/AIDS and STIs education and training on prevention and basic care, in order to encourage HIV/AIDS and STIs avoidance behavior, destigmatize the disease, and support those infected or otherwise affected by the disease.

Immunization coverage (percentage of children aged 12 to 23 months immunized against diphtheria, pertussis, and tetanus) will have increased to at least 55 percent.

\section{Status}

1,574 untrained primary school teachers received three weeks training in September 2003 under the SABABU Education project, which is funded by GoSL, ADB, and IDA for the rehabilitation of basic education. Over the period 2004-07, UNICEF will be the implementing agency for the training of unqualified teachers. 1,200 unqualified teachers in Junior Secondary School level and 4,000 unqualified teachers in primary schools are expected to be trained. Training will commence in September 2004 and end in December 2007.

Collaborative efforts of UNICEF and GoSL have resulted in the distribution of approximately 180,000 insecticide-treated bed nets as at January 2005.

The SHARP Secretariat has undertaken its first antenatal prevalence study from eight testing sites nationwide. The results reveal a national prevalence rate of 3 percent although the prevalence rate in the capital Freetown is 4 percent. The Secretariat has initiated the process of decentralization of its activities through close collaboration with the district councils. A three-month work program has been developed to facilitate this process. In addition, in collaboration with UNIFEM and UNDP, five-day capacity-enhancement training on mainstreaming HIV/AIDS into district Councils has been conducted. Centers have also been established in each district hospital for the prevention of mother-to-child transmission. A Rapid Result Initiative (RRI) is being piloted and the results obtained from the RRI show an increase in the number of people from 400-15,000 opting for VCCT within three months. The results also reflect an increase in the number of clients reporting their partners for STI treatment.

The cumulative national coverage as of June 2004 is 48.5 percent. National coverage for the first quarter of 2004 was 53 percent and for the second quarter, 44 percent. 
Table 10. Sierra Leone: Selected Social and Demographic Indicators

\begin{tabular}{|c|c|c|}
\hline & Sierra Leone & Sub-Saharan Africa \\
\hline Total land area (thousands of square kilometers) & 71.6 & $23,628.4$ \\
\hline Agricultural land (in percent of total) & 74 & 53 \\
\hline \multicolumn{3}{|c|}{ Population and vital statistics (1999, unless otherwise indicated) } \\
\hline Total population (in millions) & 5 & 644 \\
\hline Population growth rate (in percent) & 2 & 3 \\
\hline Urban population (in percent of total) & 34 & 34 \\
\hline Population density (inhabitants per square kilometer) & 65 & 27 \\
\hline \multicolumn{3}{|l|}{ Population age structure (in percent; 1996) } \\
\hline $0-14$ years & 45 & 44 \\
\hline $15-64$ years & 52 & 53 \\
\hline 65 years and above & 3 & 3 \\
\hline Infant mortality rate (per thousand) & 182 & 107 \\
\hline Life expectancy at birth (years) & 38 & 49 \\
\hline Male & 36 & 46 \\
\hline Female & 41 & 48 \\
\hline GDP per capita in U.S. dollars (2000) & 134 & 500 \\
\hline Poverty rate (in percent) $1 /$ & 82 & $\ldots$ \\
\hline \multicolumn{3}{|l|}{ Health and nutrition (2000, unless otherwise indicated) } \\
\hline \multicolumn{3}{|l|}{ Access to safe water (in percent of population) } \\
\hline Total & 34 & 46 \\
\hline Urban & 58 & 64 \\
\hline Rural & 21 & 29 \\
\hline Population per physician & 20,695 & 14,347 \\
\hline Population per hospital bed & $\ldots$ & 1,310 \\
\hline Daily per capita calorie supply & 2,035 & $\ldots$ \\
\hline Percent of requirement & 85 & $\ldots$ \\
\hline Protein intake per capita (1990; grams per day) & 44 & $\ldots$ \\
\hline \multicolumn{3}{|l|}{ Labor force (in millions; 1999) } \\
\hline Total labor force (1999) & 3 & 275 \\
\hline \multicolumn{3}{|l|}{ Percent of formal labor force (1997) } \\
\hline Female & 32 & 42 \\
\hline Agriculture & 61 & 70 \\
\hline Industry & 17 & 8 \\
\hline Services & 22 & $\ldots$ \\
\hline \multicolumn{3}{|l|}{ Education (1999) } \\
\hline \multicolumn{3}{|l|}{ Percent of age group enrolled in } \\
\hline Primary school & 42 & 78 \\
\hline Secondary school & 16 & 27 \\
\hline Tertiary education & 1 & 3 \\
\hline Adult literacy rate (in percent) & 30 & 41 \\
\hline
\end{tabular}

Sources: Statistics Sierra Leone; draft Sierra Leone 2000 "National Human Development and Related Indicators"; UNDP, Human Development Indicators , 2001; Government of Sierra Leone, "Household Survey Report on Women and Children 2000."

1/ This figure is for 1989-90. It measures the percentage of the total population living on the equivalent of under US\$1 per day in 1989-90. 
May 9, 2005

Rodrigo de Rato

Managing Director

International Monetary Fund

Washington, DC 20431

Dear Mr. de Rato:

1. In September 2001, the Executive Board approved a three-year arrangement for Sierra Leone under the Poverty Reduction and Growth Facility (PRGF). At the time of the fourth review on February 23, 2004, the arrangement was extended through March 25, 2005, owing to delays in completing the review. On November 12, 2004, the Executive Board extended the period of the PRGF arrangement further through June 25, 2005, to allow sufficient time to conclude the sixth review.

2. Economic growth in 2004 remained robust, reflecting expansion of activity in key areas of the economy. Continued political and economic stability, albeit still fragile, has bolstered public confidence. Inflation has stabilized but remains at a high level, reflecting external factors, such as the high cost of imported fuel, and underlining the need for continued pursuit of prudent fiscal and monetary policies. Going forward, government policies are aimed at promoting sustainable economic growth while improving the delivery of public services. The government has identified several key developmental areas in the recently completed Poverty Reduction Strategy Paper (PRSP), which is also guiding the country's efforts in moving toward the Millennium Development Goals (MDGs).

3. Performance under the PRGF-supported arrangement at end-December 2004 was mixed. The government met most quantitative performance criteria except the target on the domestic primary fiscal deficit, which was missed by a small margin. This was for the most part due to an increase in wage and salary payments in the fourth quarter beyond what was envisioned under the program, caused by rising salary payments to foreign missions (due to exchange rate depreciation), and clearance of backlog payments to the National Social Security and Insurance Trust (NASSIT). The outcome reflects, in part, continued capacity constraints on the part of the government to adequately manage payroll and other outlays. To strengthen payroll management and the budget process, the DfID is extending technical assistance, under a three-year program. While progress was made in implementing structural measures under the program, the reconciliation of fiscal and monetary data for 2000-02, which is a structural performance criterion subject to the sixth review, was not completed by end-November 2004 as envisioned. It now appears that a full reconciliation is virtually impossible, reflecting the more limited coverage of actual fiscal data compared to monetary survey data. Therefore, the government reconciled fiscal and monetary data for 2001-04 on the basis of a narrower definition of government than was originally intended. This is a prior action subject to the sixth review. Going forward, the government is revamping the fiscal and monetary reporting system with technical assistance from the Fund, in order to facilitate a full reconciliation of fiscal and monetary data. 
4. Furthermore, the government has completed three other measures as prior actions subject to the sixth review, reflecting their importance for the program. First, urban and suburban schools, except mission-operated primary schools, have opened individual bank accounts for the payment of teachers' salaries. Second, identification cards have been issued to all civil servants. And, third, the government has taken a definitive cabinet decision regarding clearance of the outstanding large domestic arrears.

5. In view of the foregoing, the government of Sierra Leone requests for waivers on the nonobservance of the end-December 2004 quantitative performance criterion on the domestic primary budget deficit, and on the nonobservance of the structural performance criterion related to the completion of the reconciliation of fiscal and monetary data for 2000-02. The government of Sierra Leone requests the completion of the sixth review under the PRGF arrangement and the release of the final disbursement, in the amount of SDR 14 million.

6. The government is resolute in maintaining the current cooperation with the IMF and to initiate discussions for a new PRGF-supported program after the completion of the sixth review. It has agreed with Fund staff on quarterly indicative targets for 2005. The government would like to request for an advance of the additional interim HIPC assistance for the period up to December 2005. This additional interim assistance is needed because Sierra Leone's external position remains fragile and the assistance would help smooth out the obligations falling due to the Fund. The previous Fund interim assistance committed under the HIPC Initiative expired on March 20, 2005.

7. The full Poverty Reduction Strategy Paper, completed in February 2005, was sent to you and the management of the World Bank on February 9, 2005. A Consultative Group meeting with donors is scheduled for early June 2005 in Paris, during which the government plans to seek financing for the PRSP activities, including the filling of the financing gap that has emerged as a result of the government's commitment to raise the share of poverty-related outlays in the budget.

8. The government authorizes the publication of this letter by the Fund, including the posting of the document on the IMF website, subsequent to Executive Board approval.

Sincerely yours, $/ \mathrm{s} /$

Joseph B. Dauda

Minister of Finance

Freetown, Sierra Leone

Attachments 
Table 1 Sierra Leone: Quantitative Performance Criteria and Indicative Targets
er the Poverty Reduction and Growth Facility Arrangement (January-December 2004$)$ (a)

(Cumulative change from beginning of calendar year to end of month indieted in millions of leones, unless otherwise indicated) I/

\begin{tabular}{|c|c|c|c|c|c|c|c|c|c|c|c|c|c|c|c|c|}
\hline & \multirow{2}{*}{\multicolumn{12}{|c|}{$\begin{array}{lr}\text { June } 16 / 2004 \\
\end{array}$}} & \multirow{2}{*}{\multicolumn{4}{|c|}{ December 17/ }} \\
\hline & & & & & & & & & & & & & & & & \\
\hline & $\begin{array}{c}\text { Performance } \\
\text { Criteria }\end{array}$ & $\begin{array}{c}\text { Adjusted } \\
\text { PCs }\end{array}$ & Act. & $\begin{array}{l}\text { Met or } \\
\text { Not met }\end{array}$ & $\begin{array}{c}\begin{array}{c}\text { Indicative } \\
\text { Targets }\end{array} \\
\end{array}$ & $\begin{array}{c}\begin{array}{c}\text { Adjusted } \\
\text { targets }\end{array} \\
\end{array}$ & Act. & $\begin{array}{c}\text { Met or } \\
\text { Not met }\end{array}$ & $\begin{array}{c}\begin{array}{c}\text { Indicative } \\
\text { Targets }\end{array} \\
\text {. }\end{array}$ & $\begin{array}{l}\text { Adjusted } \\
\text { targets }\end{array}$ & Act. & $\begin{array}{c}\text { Met or } \\
\text { Not met }\end{array}$ & $\begin{array}{l}\begin{array}{l}\text { Performance } \\
\text { Criteria } 17 /\end{array} \\
\end{array}$ & $\begin{array}{l}\text { Adjusted } \\
\text { targets }\end{array}$ & Prel. & $\begin{array}{l}\text { Met or } \\
\text { Not met }\end{array}$ \\
\hline \multicolumn{17}{|l|}{ Performance criteria } \\
\hline Net domestic bank credit to the central government (ceiling) $2 / 3 /$ & $-25,000$ & 9,454 & 25,292 & Not met & $-5,000$ & 15,540 & 35,073 & Not met & $-2,000$ & 13,950 & 48,439 & Not met & $-9,255$ & $-35,675$ & $-51,891$ & Met \\
\hline Unadjusted target (ceiling) & & $-25,000$ & & & & $-5,000$ & & & & $-2,000$ & & & & $-9,255$ & & \\
\hline Adjustment for the shortfall (excess) external budget support & & $-37,908$ & & & & $-31,722$ & & & & $-52,011$ & & & & 28,122 & & \\
\hline Adjustment for the issuance of treasury securities to the private sector & & 3,454 & & & & 11,183 & & & & 36,061 & & & & $-1,702$ & & \\
\hline Net domestic assets of the central bank (ceiling) $2 / 4 / 5 /$ & $-5,000$ & 40,849 & 23,633 & Met & 23,000 & 64,111 & 20,833 & Met & 26,000 & 93,910 & 11,191 & Met & 15,048 & $-4,316$ & $-43,435$ & Met \\
\hline Unadjusted target (ceiling) & & $-5,000$ & & & & 23,000 & & & & 26,000 & & & & 15,048 & & \\
\hline $\begin{array}{l}\text { Adjustment for the shortfall (excess) external budget support } \\
\text { A }\end{array}$ & & $-37,908$ & & & & $-31,722$ & & & & $-52,011$ & & & & 28,122 & & \\
\hline 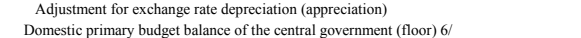 & & 7,941 & & & & $\begin{array}{r}9,389 \\
8.415\end{array}$ & & & & $\begin{array}{r}15,899 \\
-10958\end{array}$ & & & & 8,758 & & \\
\hline $\begin{array}{l}\text { Domsestit primary buddet balance of the central government (flloor) } 67 \\
\text { Subsidies to National Power Authority (ceiling) }\end{array}$ & $-46,090$ & $-46,049$ & $\begin{array}{ll}-25,445 \\
0.00\end{array}$ & $\begin{array}{l}\text { Met } \\
\text { Met }\end{array}$ & $\begin{array}{l}-81,415 \\
0.0\end{array}$ & -81,415 0.0 & $\begin{array}{lll}-51,253 \\
0.0\end{array}$ & $\begin{array}{l}\text { Met } \\
\text { Met }\end{array}$ & $\begin{array}{l}-109,578 \\
0.0\end{array}$ & $\begin{array}{l}-109,578 \\
0.0\end{array}$ & 0.0 & $\begin{array}{l}\text { Met } \\
\text { Met }\end{array}$ & $\begin{array}{l}-81,361 \\
0.0\end{array}$ & $-81,361$ & $-84,060$ & $\begin{array}{c}\text { Not tet } \\
\text { Met }\end{array}$ \\
\hline Gross foreign exchange reserves of the central bank (in millions of U.S. dollars (flloor) ) $7 /$ & 18.31 & -10.85 & 7.90 & Met & 5.67 & -18.73 & 0.40 & Met & 21.7 & -12.2 & -0.73 & Met & 22.5 & 30.4 & 65.5 & Met \\
\hline Unadiusted target (floor) & & 18.31 & & & & 5.67 & & & & 21.7 & & & & 22.5 & & \\
\hline 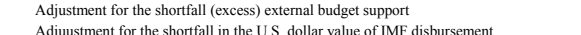 & & -29.16 & & & & -24.40 & & & & -14.45 & & & & 7.87 & & \\
\hline \multicolumn{17}{|l|}{ 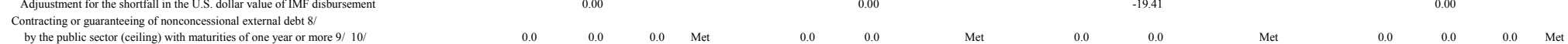 } \\
\hline by the public sector (ceiling) with maturities of one year or more $9 / 10 /$ & 0.0 & 0.0 & 0.0 & Met & 0.0 & 0.0 & & Met & 0.0 & 0.0 & & Met & 0.0 & 0.0 & 0.0 & Met \\
\hline $\begin{array}{l}\text { Outstanding stock of external debt owed or guaranteed by the public sector } 11 / \\
\text { with mans }\end{array}$ & & & & & & & & & & & & & & & & \\
\hline $\begin{array}{l}\text { with maturitites of less than one year (ceiling 12/ } \\
\text { Exxtemal paynent arrears of the public sector (ceiling) 13/ }\end{array}$ & $\begin{array}{l}0.0 \\
0.0\end{array}$ & 0.0 & 0.0 & Met & $\begin{array}{l}0.0 \\
0.0\end{array}$ & 0.0 & & Met & 0.0 & 0.0 & & Met & 0.0 & 0.0 & 0.0 & Met \\
\hline \multicolumn{17}{|l|}{ Indicative targets } \\
\hline Total domestic government revenue (floor) & 82,642 & 82,642 & 80,025 & Not met & 165,967 & 165,967 & 174,734 & Met & 248,495 & 248,495 & 264,589 & Met & 348,083 & 348,083 & 356,966 & Met \\
\hline Government wage bill (ceiling) & 43,023 & 43,023 & 42,604 & Met & 86,045 & 86,045 & 85,941 & Met & 129,068 & 129,068 & 125,064 & Met & 173,825 & 173,825 & 177,243 & Not met \\
\hline Poverty-related expenditures (floor) & 54,937 & 54,937 & 29,048 & Not met & 102,888 & 102,888 & 68,167 & Not met & 139,573 & 139,573 & 106,324 & Not met & 150,522 & 150,522 & 134,691 & Not met \\
\hline \multicolumn{17}{|l|}{ Memorandum items: } \\
\hline Extermal budgetary assistance 14 & 75,816 & & 0 & & 103.007 & & 26,006 & & 142.007 & 142.007 & 63.404 & & 170.467 & 170.467 & 199.196 & \\
\hline Net redit to the central government by nonbank private sector $15 /$ & 556 & & 4,008 & & 11,513 & & 22,694 & & 11,406 & 11,406 & 41,771 & & 51,230 & 51,230 & 49,528 & \\
\hline
\end{tabular}

Sources: Sierra Leonean authorities; and IMF staff calculations

1/ Variables are based on definitions in the technical memorandum of understanding (TMU) of October 2004

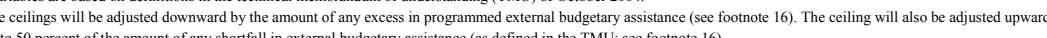

up to the ceiling on net domestic bank credit to the central government.
The program benchmarks for December 2003 - June 2004 are valued at the program exchange rate as defined in the technical memorandum of understanding (TMU) of December 2003 .

Defined as domestic revenue minus total expenditure and net lending, excluding interest payments, externally financed capital expenditures, and the externally financed DDR progran

7/ In the event of an excess (shortfall in external budgetary assistance (as defined above), the floo

ent equivalent to 35 percent or more, calculated using a discount rate

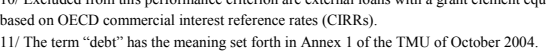

Excluded from this performance criterion are normal import-related credits

rin are those debts subject to rescheduling arrangements

15/Comprises treasury bills purchased by the National Social Security and Insurance Trust (NASSIT) and the non-financial private sector.

16)/ Quantitative performance criteria and indicative targets as specified in Table 3 (IMF Country Report No. 04/49). 
Table 2. Sierra Leone: Prior Actions and Structural Benchmarks Subject to the Sixth Review

Under the Program Supported by the Poverty Reduction and Growth Facility Arrangement

\section{Prior action}

A limited reconciliation of fiscal and monetary data for 2001-04 has been completed.

All urban and suburban schools, except mission-operated primary schools, have

Observed opened individual bank accounts for the payment of teachers' salaries.

Terms and conditions for securitization of all remaining verified domestic arrears have been announced publicly.

\section{Benchmarks}

Specific measures have been elaborated to strengthen the Auditor General's Office, including the use of private accounting firms to expedite audits of government ministries and agencies.

The Budgeting and Accountability Act has been presented to parliament.

The Establishment Secretary's Office (ESO) database of civil servants and teachers is updated monthly and used to update the payroll database of the Accountant General's Office.

Employment ceilings for individual schools will be published in the government gazette at the beginning of each school year.

Diagnostic studies and reforms have been completed in six key ministries to rationalize structure, functions, and staffing in these ministries.

A medium-term budgetary framework incorporating all major mineral revenues has been formulated and discussed with development partners.

Project has been launched to convert the ESO into a personnel management office.
$1 \quad$ December 31, 2004

Partially observed

2 October 31, 2004

Observed

3 Continuous

Observed

4

Continuous

Observed

$5 \quad$ December 31, 2004

Partially observed

6 August 31, 2004

Not observed

7 December 31, 2004

Not observed 
Table 3. Sierra Leone: Indicative Targets for 2005

(Cumulative change from beginning of calendar year to end of month indicated; in millions of leones, unless otherwise indicated.) $1 /$

\begin{tabular}{|c|c|c|c|c|}
\hline & $\begin{array}{c}\text { March } \\
\text { Indicative } \\
\text { Targets } \\
\end{array}$ & $\begin{array}{c}\text { June } \\
\text { Indicative } \\
\text { Targets } \\
\end{array}$ & $\begin{array}{c}\text { September } \\
\text { Indicative } \\
\text { Targets } \\
\end{array}$ & $\begin{array}{c}\text { December } \\
\text { Indicative } \\
\text { Targets } \\
\end{array}$ \\
\hline \multicolumn{5}{|l|}{ Indicative targets } \\
\hline Net domestic bank credit to the central government (ceiling) $2 / 3 /$ & 15,375 & 21,180 & 36,403 & 12,356 \\
\hline Net domestic assets of the central bank (ceiling) $2 / 4 / 5 /$ & 31,474 & 65,255 & 103,432 & 70,503 \\
\hline Domestic primary budget balance of the central government (floor) 6/ & $-13,259$ & $-24,960$ & $-46,571$ & $-57,878$ \\
\hline Subsidies to National Power Authority (ceiling) & 0.0 & 0.0 & 0.0 & 0.0 \\
\hline Gross foreign exchange reserves of the central bank, in million U.S. dollars (floor) 7/ & -10.66 & -4.25 & -15.64 & -1.88 \\
\hline $\begin{array}{l}\text { Contracting or guaranteeing of nonconcessional external debt } \\
\text { by the public sector (ceiling) with maturities of one year or more } 8 / 9 / 10 /\end{array}$ & 0.0 & 0.0 & 0.0 & 0.0 \\
\hline $\begin{array}{l}\text { Outstanding stock of external debt owed or guaranteed by the public sector } \\
\text { with maturities of less than one year (ceiling) } 11 / 12 /\end{array}$ & 0.0 & 0.0 & 0.0 & 0.0 \\
\hline External payment arrears of the public sector (ceiling) 13/ & 0.0 & 0.0 & 0.0 & 0.0 \\
\hline Total domestic government revenue (floor) & 93,919 & 209,750 & 321,459 & 434,982 \\
\hline Government wage bill (ceiling) & 48,532 & 104,606 & 161,794 & 222,982 \\
\hline Poverty-related expenditures (floor) & 32,031 & 71,549 & 123,041 & 167,471 \\
\hline \multicolumn{5}{|l|}{ Memorandum item: } \\
\hline External budgetary assistance $14 /$ & 28,348 & 57,848 & 115,521 & 174,949 \\
\hline Net credit to government by nonbank private sector $15 /$ & 23,063 & 31,771 & 32,105 & 18,534 \\
\hline
\end{tabular}

Sources: Statistics Sierra Leone; and IMF staff estimates.

1/ Variables are based on definitions in the TMU of October 2004

2/ The ceilings will be adjusted downward by the amount of any excess in programmed external budgetary assistance (see footnote 16). The ceiling will also be adjusted upward

by up to 50 percent of the amount of any shortfall in external budgetary assistance (as defined in the TMU; see footnote 16).

3/ Defined as claims on government (net) in the monetary survey. To be adjusted downward (upward) by any net issues of government securities to the nonbank private sector

relative to the program target, up to the ceiling on net domestic bank credit to the central government.

4/ The benchmarks for January-December 2005 are valued at the exchange rate of Le 2.950 per US\$ 1

5/ Defined as the difference between the net foreign assets of the central bank (valued at the program exchange rate) and reserve money.

6/ Defined as domestic revenue minus total expenditure and net lending, excluding interest payments, externally financed capital expenditures, and the externally financed DDR program

$7 /$ In the event of an excess (shortfall) in external budgetary assistance (as defined above), the floor will be adjusted upward (downward) by the amount of the excess (shortfall).

8/ This performance criterion applies to debt as defined in Annex 1 of the TMU of October 2004.

9/ Excluded from this performance criterion are disbursements from the Fund and rescheduling arrangements.

10/ Excluded from this performance criterion are external loans with a grant element equivalent to 35 percent or more, calculated using a discount rate

based on OECD commercial interest reference rates (CIRRs).

11/ The term "debt" has the meaning set forth in Annex 1 of the TMU of October 2004

12/ Excluded from this performance criterion are normal import-related credits.

13/ To be applied on a continuous basis. Excluded from this performance criterion are those debts subject to rescheduling arrangements.

14 / Including program grants and program loans.

15/ Comprises treasury bills purchased by the National Social Security and Insurance Trust (NASSIT) and the non-financial private sector. 
Sierra Leone: Relations with the Fund

(As of February 28, 2005)

I. Membership Status: Joined 9/10/62; Article VIII

II. General Resources Account:

Quota

Fund holdings of currency

Reserve position

III. SDR Department:

Net cumulative allocation

Holdings

IV. Outstanding Purchases and Loans:

PRGF Arrangements

V. Latest Financial Arrangements:
SDR Million

103.70

103.69

0.02

SDR Million

17.45

25.07

SDR Million

126.05
$\%$ Quota

100.0

99.99

0.02

$\%$ Allocation

100.0

143.61

\% Quota

121.55

\begin{tabular}{|c|c|c|c|c|}
\hline Type & $\begin{array}{r}\text { Approval } \\
\text { Date } \\
\end{array}$ & $\begin{array}{r}\text { Expiration } \\
\text { Date }\end{array}$ & $\begin{array}{c}\text { Amount } \\
\text { Approved } \\
\text { (SDR Million) }\end{array}$ & $\begin{array}{c}\text { Amount } \\
\text { Drawn } \\
\text { (SDR Million) }\end{array}$ \\
\hline PRGF & $9 / 26 / 01$ & $6 / 25 / 05$ & 130.84 & 116.84 \\
\hline PRGF & $3 / 28 / 94$ & $5 / 04 / 98$ & 101.90 & 96.85 \\
\hline SAF & $3 / 28 / 94$ & $3 / 27 / 95$ & 27.02 & 27.02 \\
\hline
\end{tabular}

VI. Projected Payments to Fund (without HIPC assistance)

(SDR Million; based on existing use of resources and present holdings of SDRs):

Principal

Charges/interest

Total
Forthcoming

\begin{tabular}{rrrrr}
\hline$\underline{2005}$ & $\underline{2006}$ & $\underline{2007}$ & $\underline{2008}$ & $\underline{2009}$ \\
\hline 5.66 & 3.05 & 10.81 & 16.37 & 19.17 \\
$\underline{0.62}$ & $\underline{0.60}$ & $\underline{0.56}$ & $\underline{0.49}$ & $\underline{0.41}$ \\
$\underline{6.28}$ & $\underline{3.64}$ & $\underline{11.37}$ & $\underline{16.86}$ & $\underline{19.57}$
\end{tabular}


Projected Payments to Fund (with Board-approved HIPC Initiative Assistance)

(SDR Million; based on existing use of resources and present holdings of SDRs):

\begin{tabular}{lrlrrr} 
& \multicolumn{5}{c}{ Forthcoming } \\
\cline { 2 - 6 } & $\underline{\underline{2005}}$ & $\underline{2006}$ & $\underline{2007}$ & $\underline{2008}$ & $\underline{2009}$ \\
Principal & 5.61 & 3.05 & 10.81 & 16.37 & 19.17 \\
Charges/interest & $\underline{0.62}$ & $\underline{0.60}$ & $\underline{0.56}$ & $\underline{0.49}$ & $\underline{0.41}$ \\
$\quad$ Total & $\underline{\underline{6.23}}$ & $\underline{3.64}$ & $\underline{11.37}$ & $\underline{16.86}$ & $\underline{19.57}$
\end{tabular}

\section{Implementation of HIPC Initiative}

Commitment of HIPC Initiative assistance

Decision point date

Assistance committed (NPV terms) ${ }^{34}$

Total assistance by all creditors (F94million)

Of which: IMF assistance (US\$ million)

(SDR equivalent in millions)

Completion point date

Enhanced

Framework

Disbursement of IMF assistance (SDR million)

Amount disbursed

62.03

Interim assistance

62.03

Completion point balance $\quad 0.0$

Total disbursements $\quad 62.03$

VIII. Safeguards Assessment

Under the Fund's safeguards assessment policy, the Bank of Sierra Leone (BSL) is subject to an assessment with respect to the PRGF arrangement, which was approved on September 26, 2001, and is scheduled to expire on June 25, 2005. A safeguards assessment of the BSL was completed on July 29, 2002. The assessment concluded that substantial risks may exist in the financial reporting framework. Staff findings, proposed recommendations under program conditionality, and other recommendations are reported in "Sierra Leone-Second Review Under the Poverty Reduction and Growth Facility and Request for a Waiver of Performance Criteria." Measures are being implemented by the BSL and implementation of staff recommendations continue to be monitored by staff.

\section{Exchange Rate Arrangement}

\footnotetext{
${ }^{34}$ Net present value (NPV) terms at the decision point under the enhanced framework.
} 
Since April 25, 1990, the exchange rate has been market-determined. Commercial banks may buy and sell foreign exchange from/to individual customers, as well as trade among themselves or with the BSL on a freely negotiable basis. The BSL calculates an official exchange rate every Friday morning as the weighted average of the auction rate, the commercial banks' mid-rate, and the bureaus' mid-rate in the previous week, for customs valuation purposes and for official transactions. As of March 23, 2005, the BSL mid-rate was Le 2,866.29=US\$1. The exchange rate regime is classified as "independently floating."

With effect from December 14, 1995, Sierra Leone has accepted the obligations of Article VIII, Sections 2, 3, and 4. On June 29, 2001, Sierra Leone removed the remaining exchange restriction, in the form of a tax clearance certificate required for payments and transfers of certain types of current international transactions.

\section{Article IV Consultation}

The 2004 Article IV consultation was concluded by the Executive Board on November 12, 2004. The next Article IV consultation with Sierra Leone will be held in accordance with the provisions of the decision on consultation cycles approved on July 15, 2002.

\section{Technical Assistance}

\begin{tabular}{|l|l|}
\hline Missions & Date \\
\hline MFD mission on improving foreign exchange auction. & January/February 2000 \\
\hline $\begin{array}{l}\text { FAD mission to conduct fiscal sector review and to recommend } \\
\text { reforms in expenditure management and revenue administration. }\end{array}$ & May 2001 \\
\hline MFD mission on financial sector issues. & October 1999 \\
\hline $\begin{array}{l}\text { MFD mission on banking supervision and regulation; monetary } \\
\text { operations and framework; and payment systems. }\end{array}$ & May/June 2001 \\
\hline $\begin{array}{l}\text { MFD mission to assess TA needs of the BSL, banking supervision, } \\
\text { and central bank management. }\end{array}$ & November 2001 \\
\hline FAD mission to review public expenditure management systems. & June 2002 \\
\hline $\begin{array}{l}\text { STA mission to assess the legal-institutional framework for statistics. } \\
\text { MFD mission on banking supervision and regulation and monetary } \\
\text { operations and framework. }\end{array}$ & June 2002 \\
\hline STA GDDS project mission on monetary and financial accounts. & April 2003 \\
\hline STA GDDS project mission on BOP. & April 2003 \\
\hline $\begin{array}{l}\text { MFD mission on monetary operations, banking supervision, and } \\
\text { payment systems. }\end{array}$ & May/June 2003 \\
\hline
\end{tabular}




\begin{tabular}{|l|l|}
\hline Missions & Date \\
\hline STA GDDS follow-up project mission on BOP. & November 2003 \\
\hline $\begin{array}{l}\text { MFD mission to provide and plan follow-up TA to the BSL on } \\
\text { monetary operations, banking supervision, and payment systems. }\end{array}$ & November 2003 \\
\hline $\begin{array}{l}\text { FAD mission to review the tariff and indirect tax system, National } \\
\text { Revenue Authority, and tax and customs administration. }\end{array}$ & February 2004 \\
\hline STA GDDS project mission on strategic planning. & March 2004 \\
\hline $\begin{array}{l}\text { FAD mission to review the system of fiscal incentives, especially the } \\
\text { special tax regimes applied to mining and petroleum sectors. }\end{array}$ & March/April 2004 \\
\hline STA GDDS project mission on national accounts. & April 2004 \\
\hline $\begin{array}{l}\text { STA GDDS project study tour for Sierra Leonean officials to Kenya } \\
\text { on strategic planning. }\end{array}$ & August 2004 \\
\hline STA GDDS project mission on national accounts. & September 2004 \\
\hline STA GDDS project mission on BOP issues. & September/October 2004 \\
\hline $\begin{array}{l}\text { STA GDDS project mission on monetary-fiscal accounts } \\
\text { reconciliation. }\end{array}$ & October 2004 \\
\hline MFD multi-topic technical assistance mission. & November 2004 \\
\hline $\begin{array}{l}\text { STA GDDS project mission on monetary-fiscal accounts } \\
\text { reconciliation. }\end{array}$ & February 2005 \\
\hline STA GDDS project mission on national accounts. & February 2005 \\
\hline
\end{tabular}

\section{Resident Representative}

A Fund resident representative was stationed in Freetown until May 1997. 


\section{Sierra Leone: Relations with the World Bank Group}

The Bank's Board endorsed a Transitional Support Strategy (TSS) for Sierra Leone for FY 2002-03 on March 26, 2002. Under the TSS, the World Bank, through IDA, has assisted the government in pursuing four main objectives: (i) consolidating peace; (ii) resettlement, reconstruction and reintegration; (iii) improving governance; and (iv) maintaining a macroeconomic framework conducive to recovery. Instruments used in supporting these objectives include the second Public Sector Management Support Project (PSMS II), the Second and Third Economic Rehabilitation and Recovery Credits (ERRC II and III), the Basic Education Project, the Health Sector Reconstruction Project, the Transport Sector project (now called Power and Water), the Institutional Reform and Capacity Building Project (IRCB), and the National Social Action Project. The Bank also supports the Government's HIV/AIDS Program through the Multi-Sector HIV/AIDS Response Project approved in 2002 under the MAP II.

The Bank is now preparing a new Country Assistance Strategy (CAS) following continued progress in establishing security and governance as well as the completion of the new PRSP. The new CAS will support the strategy outlined in the PRSP for a transition to policies and programs for sustained growth and poverty reduction with gradually decreasing emphasis on post-conflict needs. The continued maintenance of a stable macroeconomic framework is considered to be a prerequisite for World Bank program support.

In FY 2003, the Bank provided US\$15 million in adjustment support (ERRC III), US\$20 million for the Rehabilitation of Basic Education, US\$20 million for Health Reconstruction and Development, and US\$35 million for the National Social Action Project for a total of US\$90 million. In FY 2004, lending included only the US\$25 million for the Institutional Reform and Capacity Building Project. In FY05, the lending program includes US\$15 million in adjustment support (ERRG IV), \$35 million for Power and Water, and \$14.5 million for Bumbuna Hydroelectric Power Support. In FY 2006, the planned lending includes only the IDP-Transport project for a total of US\$38 million.

As of March 1, 2005, the World Bank Group has approved 46 loans, credits and grants for a total of US\$721.2 million, with an undisbursed amount of US\$135.8 million. The current portfolio consists of six operations, as summarized in the table below, in the areas of adjustment support, poverty reduction, education, health, HIV/AIDS, transportation, power and public sector management totaling about US\$150 million. 
Sierra Leone: Financial Relations with the World Bank Group

(As of March 1, 2005; in millions of U.S. dollars)

\begin{tabular}{lccc}
\hline & \multicolumn{2}{c}{ Commitments } & $\begin{array}{c}\text { Of which: } \\
\text { Undisbursed }\end{array}$ \\
& IBRD & & \\
\hline IBRD/IDA lending operations & & & \\
Rehabilitation of Basic Education & 0.00 & 20.0 & 17.8 \\
National Social Action Project & 0.00 & 35.0 & 29.2 \\
Health Sector Reconstruction & 0.00 & 20.0 & 20.2 \\
HIV/AIDS Response Project & 0.00 & 15.0 & 11.4 \\
Institutional Reform and Capacity Building & 0.00 & 25.0 & 23.1 \\
Power and Water & 0.00 & 35.0 & 35.4 \\
Total & 0.00 & 150.0 & 137.1 \\
Total disbursed (IBRD and IDA) & 18.70 & $565.21 /$ & \\
Of which: repaid & 18.16 & 35.4 & \\
\hline
\end{tabular}

Source: World Bank Group.

1/ Of which, US\$65.1 million is grants.

World Bank Contact: Douglas M. Addison, Senior Economist, Macroeconomics 4, Africa Region, the World Bank (phone: 202-473-1188). 


\section{Sierra Leone: Statistical Issues}

1. Due to the prolonged civil war, Sierra Leone's macroeconomic database has serious deficiencies, particularly in the areas of the balance of payments, national accounts, and social indicators. From the May 1997 coup to March 1998, statistical compilation virtually collapsed because of institutional damage and the departure of key skilled personnel from the administration. Since April 1998, however, the authorities have endeavored to rehabilitate the data collection and compilation systems. The authorities are fully cooperative in providing data to the Fund for the purposes of policy formulation and program monitoring. The authorities are also trying to disseminate economic and financial data to the public on a regular basis.

2. A major and sustained improvement in the coverage and timeliness of economic data will require the restructuring of the institutional framework along the lines of recommendations by the March 2004 IMF/World Bank mission on the development of a strategic plan for the statistical system in Sierra Leone. Budgetary resources remain scarce for the main statistical unit, the Statistics Sierra Leone (SSL); this situation most adversely affects the compilation of national accounts and price statistics. Cooperation and coordination between the main statistical agencies also need to be improved. Sierra Leone is participating in the GDDS regional project for Anglophone African countries that is funded by the Department for International Development (DfID) of the U.K. The authorities have prepared an initial set of metadata that include detailed plans for improvement over the short and medium term; these were posted on the Fund's DSBB on May 29, 2003. These metadata were subsequently updated in August 2004. Sierra Leone has received Fund technical assistance in priority areas and additional assistance is expected to be requested in the context of the GDDS project.

\section{National accounts}

3. National accounts data are prepared by the SSL using data received from government ministries and agencies, public enterprises, and through occasional surveys of economic activity. The consumer price index (CPI) is used extensively to derive estimates of GDP at constant prices. A project to improve the system of national income and social accounts was undertaken with Fund/United Nations Development Program (UNDP) technical support. As a result, a set of revised national accounts for the period 1986/87-1994/95 was published in December 1995. The main revisions involved the adjustment of trade figures to reflect illegal diamond mining and fishing activity. However, large adjustments were also made to the exports of nonfactor services, for which the SSL was unable to provide sufficient explanation. Data on the exports and imports of services need further improvement and efforts are ongoing to strengthen direct estimation techniques. Fund missions continue to make their own estimates and projections of key national accounts aggregates, as well as adjustments to historical data using available information. The latest available national accounts data refer to 2003. Resource constraints have significantly delayed data production for 2001 and 2002. The SSL should focus on the development of a new benchmark for the 
current price estimates and to rebase the constant price estimates to a new base (current base year is 1990).

4. A national accounts expert visited Freetown in March/April and September 2004, and again in March 2005 under the GDDS project. The expert reviewed the source data, methodologies, and compilation issues. The expert prepared and agreed with the authorities on a short-term action plan that would bridge the gap to the longer-term improvements that are to be incorporated into the strategic plan. Plans are underway to prepare revised national accounts, for 2001 onwards. However, shortages of resources and staff are major constraints.

\section{Prices}

5. The CPI is compiled on a monthly basis by the SSL and published with a lag of about three weeks. The CPI covers the capital city and three towns. The 1992 base period was derived from a supplemental survey to the 1989/90 Household Expenditure Survey. Plans are underway to re-base the CPI to 2004, based on the 2003 Sierra Leone integrated household survey. The production of wholesale price and producer price indices remain medium-term goals.

\section{Government finance statistics}

6. The budget reporting system was established with technical assistance provided under the Fund/UNDP technical assistance project. Monthly data on central government revenue, current expenditure, and financing are provided, with appropriate desegregation. The European Commission (EC) is providing technical assistance to the Accountant General's Office that will improve the timeliness and quality of fiscal data. Data on capital expenditure are poor. While Sierra Leone has reported fiscal data to AFR, it has not provided annual data for publication in the GFS Yearbook since 1999. Fiscal data only cover the budgetary central government, excluding extrabudgetary agencies and local governments.

7. There is an urgent need for greater timeliness and accuracy of data on foreignfinanced development projects. Reports on the implementation of the development budget and its financing are currently not produced in a format that is suitable for budget analysis. In particular, data on the implementation is missing. There is also need for assuring quality control of the final data. The authorities are currently considering the introduction of a flash reporting system for government expenditure in general- and foreign aid-financed projects. In the context of the GDDS regional project for Anglophone African countries (funded by the U. K. Department for International Development (DfID)), work has been undertaken to reconcile fiscal and monetary data, and to improve the coverage and classification of these two data sets (see below). This reconciliation is a performance criterion in Sierra Leone's PRGF program with the Fund. 


\section{Monetary statistics}

8. The main components of the central bank balance sheet are available on a daily and weekly basis; this system provides an early warning system on key financial targets. The full monetary survey is prepared with a lag of about six weeks, with comprehensive coverage of commercial banks.

9. The Bank of Sierra Leone (BSL) is compiling monetary data using a compilation system established by the 1996 STA mission for data reporting to AFR and STA. Most of the mission's recommendations have been implemented, resulting in substantial improvements in the quality of the monetary data. However, commercial banks continue to distinguish between their foreign and domestic positions based only on the currency of denomination and not on residency. In addition, the April-May 2003 GDDS metadata and monetary and financial statistics mission identified that (i) the institutional coverage of monetary statistics does not include those financial corporations that accept nontransferable deposits and (ii) the $\mathrm{BSL}$ records the counterpart to the foreign exchange received through foreign grants and loans to the central government as foreign liabilities instead of liabilities to the central government. Some other data problems result from mispostings in the balance sheet of the BSL and misclassifications of new accounts. Also, bank reserves as reported by the BSL and commercial banks do not match. After considerable work by the authorities and commercial banks, the misclassification of government deposits has only been resolved for 2003 .

10. The October 2004 mission on the reconciliation of fiscal and monetary statistics indicated that such reconciliation is very difficult due in part to (i) the fact that the fiscal data are compiled only on a cash basis, and (ii) incomplete definition of the central government. Even though the authorities undertook an exercise in 2003 to identify government accounts in the banking system, the review of the list of government agencies revealed significant shortcomings. The mission recommended that the authorities develop a reliable definition of the central government for statistical purposes. A follow-up mission to continue the work in the fiscal accounts is expected to take place in FY 2005.

\section{Balance of payments statistics}

11. The BSL is responsible for the compilation of the balance of payments for Sierra Leone. The BSL obtains the data for the balance of payments estimates from various sources including the SSL, government ministries, the Customs and Excise Department (Customs), and the "Financial Survey of Major Limited Companies," for data on foreign direct investment. Goods estimates are based on the import and export data compiled by Customs and are adjusted for coverage, valuation, and timing to fit the balance of payments definitions. However, the BSL does not make adjustments to BOP data using supplementary information to take account of unreported data.

12. Sierra Leone's external transactions are characterized by a large volume of activity in the informal sector, owing principally to the smuggling of diamonds. A considerable portion 
of imports is financed by these unrecorded exports. As a result, official balance of payments statistics tend to substantially understate transactions. The staff has been addressing this problem through the use of third-country (principally EC member) import data. The Fund's Statistics Department (STA) is providing technical assistance under the GDDS project to help the authorities with the implementation of the Balance of Payments Manual, Fifth Edition BPM5.

13. Outstanding data problems exist with regard to trade in services, income statistics, current transfers, and in the financial and capital accounts. Regarding the latter, there are, in principle, substantial difficulties in tracking financial transactions of the public and private sectors that are not routed through the central bank but through commercial banks. While the authorities are able to report accurately what public sector debt service payments are after debt relief, they have difficulties in estimating debt service due before debt relief. These difficulties are manifested in reconciling flow data in the balance of payments and stocks in the international investment position. In particular, the impact of external debt relief on the international investment position is not recorded correctly. Estimates of smuggled imports and exports, in particular diamonds, are also not available.

Against this background, information on official program grant and loan receipts is relatively good and is prepared by the staff on the basis of contact with the Sierra Leonean authorities and donor agencies. In contrast, data on private capital flows are very poor. Some information on private banking flows can be derived from the monetary survey. Other private capital flows, especially those linked to the informal diamond trade, are effectively captured only in "Errors and omissions." Data on the gross and net official reserves positions of the BSL are provided monthly to the Fund with a short lag. STA has been providing technical assistance on BOP issues in the context of the GDDS project and the most recent visit took place in September/October 2004. STA is in contact with the authorities in an effort to reconcile balance of payments flow data with stock data in the international investment position. 
Sierra Leone: Table of Common Indicators Required for Surveillance

(As of April 13, 2005)

\begin{tabular}{|c|c|c|c|c|c|}
\hline & $\begin{array}{c}\text { Date of } \\
\text { latest } \\
\text { observation }\end{array}$ & $\begin{array}{l}\text { Date } \\
\text { received }\end{array}$ & $\begin{array}{c}\text { Frequency } \\
\text { of } \\
\text { Data }^{6}\end{array}$ & $\begin{array}{l}\text { Frequency } \\
\text { of } \\
\text { Reporting }^{6}\end{array}$ & $\begin{array}{c}\text { Frequency } \\
\text { of } \\
\text { publication }\end{array}$ \\
\hline Exchange Rates & $3 / 05$ & $4 / 05$ & $\mathrm{D}$ & $\mathrm{W}$ & $\mathrm{W}$ \\
\hline International Reserve Assets and Reserve Liabilities of the Monetary Authorities ${ }^{1}$ & $8 / 04$ & $9 / 04$ & $\mathrm{M}^{7}$ & M & $\mathrm{W}$ \\
\hline Reserve/Base Money & $12 / 04$ & $1 / 05$ & $\mathrm{M}^{8}$ & M & M \\
\hline Broad Money & $12 / 04$ & $1 / 05$ & $M^{7}$ & M & M \\
\hline Central Bank Balance Sheet & $12 / 04$ & $1 / 05$ & $M^{8}$ & M & M \\
\hline Consolidated Balance Sheet of the Banking System & $12 / 04$ & $1 / 05$ & $\mathrm{M}^{8}$ & M & M \\
\hline Interest Rates ${ }^{2}$ & $2 / 05$ & $3 / 05$ & $\mathrm{~W}$ & M & $\mathrm{W}$ \\
\hline Consumer Price Index & $11 / 04$ & $1 / 05$ & M & M & M \\
\hline Revenue, Expenditure, Balance and Composition of Financing ${ }^{3}-$ General Government $^{4}$ & $12 / 04$ & $2 / 05$ & M & M & N/A \\
\hline Revenue, Expenditure, Balance and Composition of Financing ${ }^{3}$ - Central Government & $12 / 04$ & $2 / 05$ & M & M & $\mathrm{N} / \mathrm{A}$ \\
\hline Stocks of Central Government and Central Government-Guaranteed Debt ${ }^{5}$ & $12 / 04$ & $2 / 05$ & M & M & N/A \\
\hline External Current Account Balance & 2003 & $7 / 04$ & A & $\mathrm{V}$ & A \\
\hline Exports and Imports of Goods and Services & $7 / 04$ & $7 / 04$ & M & M & M \\
\hline GDP/GNP & 2003 & $7 / 04$ & A & $\mathrm{V}$ & A \\
\hline Gross External Debt & 2004 Q1 & $7 / 04$ & M & $\mathrm{M}$ & $\mathrm{M}$ \\
\hline
\end{tabular}

${ }^{1}$ Includes reserve assets pledged or otherwise encumbered as well as net derivative positions.

${ }^{2}$ Both market-based and officially-determined, including discount rates, money market rates, rates on treasury bills, notes and bonds.

${ }^{3}$ Foreign, domestic bank, and domestic nonbank financing.

${ }^{4}$ The general government consists of the central government (budgetary funds, extra budgetary funds, and social security funds) and state and local governments.

${ }^{5}$ Including currency and maturity composition.

${ }^{6}$ Daily (D), Weekly (W), Monthly (M), Quarterly (Q), Annually (A); Irregular (I); Not Available (NA)

${ }^{7}$ Weekly estimates provided in Bank of Sierra Leone's "Daily Indicators"

${ }^{8}$ Daily estimates provided in Bank of Sierra Leone's "Daily Indicators" 


\section{A Tentative Work Program}

Discussions on a new arrangement

Presentation of the new arrangement to the Board
June 2005

September 2005 


\section{Statement by the IMF Staff Representative \\ June 1, 2005}

The following supplementary information has become available since the issuance of the staff report. This information does not alter the thrust of the staff's assessment contained in the above-mentioned document.

- The World Bank and UNDP, after consultation with the government of Sierra Leone, issued a press statement on May 20, 2005 postponing the Consultative Group meeting on Sierra Leone from early June to the last quarter of the year. This has been done to allow further progress in implementing the PRSP and to provide time for mobilizing more partners to join in coordinated financing. The government and development partners are convinced that a postponement would allow a buildup of momentum and further support to Sierra Leone. 
June 2, 2005

\section{IMF Executive Board Completes Sixth and Final Review Under Sierra Leone's PRGF Arrangement and Approves US\$20.8 Million Disbursement}

The Executive Board of the International Monetary Fund (IMF) has completed the sixth and final review of Sierra Leone's performance under an SDR 130.8 million (about US\$194.3 million) Poverty Reduction and Growth Facility (PRGF) arrangement (see Press Release No. 01/39). With the completion of this review, Sierra Leone would be able to draw SDR 14 million (about US\$20.8 million).

In addition, the Executive Board approved additional interim assistance of SDR 4 million (about US\$5.9 million) under the enhanced Heavily Indebted Poor Country (HIPC) Initiative for the period until end-2005.

The Board also waived the nonobservance of an end-December 2004 quantitative performance criterion on the domestic primary balance of the central government, as the margin of the nonobservance of this criterion was minor, as well as an end-November 2004 structural performance criterion to complete the reconciliation of fiscal and monetary data for 2000-2002; a more limited reconciliation of fiscal and monetary data for 2001-2004 was completed as a corrective action for the nonobservance of this structural performance criterion.

Following the Executive Board's discussion of Sierra Leone's economic performance on June 1, 2005, Mr. Agustín Carstens, Deputy Managing Director and Acting Chair, made the following statement:

"Sierra Leone made further progress in 2004 toward completing the post-conflict transition and successfully held local government elections. The elections represent an important step toward decentralizing government and providing key public services. The mandate of the United Nations peacekeeping mission for Sierra Leone, UNAMSIL, has been extended to December 2005 , in order to allow more time for the government to strengthen security.

"The emergence of peace in recent years has paved the way for an enduring and broad-based economic recovery, reflecting robust activity in agriculture, diamond mining, manufacturing, and services. However, inflation was high, in part reflecting more accommodative fiscal and monetary policies during the first half of the year. More generally, performance under the PRGF- 
supported program has improved during recent months, and remedial actions are being taken where necessary.

"The 2005 macroeconomic framework envisages the continuation of robust output growth. Mining, agriculture, and services are expected to continue to lead the expansion. Inflation is projected to decline to a single digit as a result of tighter fiscal and monetary policies. Sustained implementation of sound policies will be essential for ensuring macroeconomic stability and promoting strong growth and much-needed progress in poverty reduction. Continued support from the donor community and enhanced donor coordination will be especially important in view of Sierra Leone's significant capacity constraints and financing needs.

"On fiscal policy, the authorities need to continue with tax efforts and institutional reforms for enhancing domestic revenue collection. Expenditure trends should reflect key development priorities, as outlined in the government's poverty-reduction strategy paper. The authorities also need to keep in view the strategic role of privatization, as a way to enhance domestic revenues and to improve economic efficiency.

"Monetary policy needs to be more proactive. The Bank of Sierra Leone should continue to widen its menu of instruments, supported in part through the Fund's ongoing technical assistance. To safeguard the soundness of the banking system, the authorities should strengthen bank supervision and ensure that banks are adequately capitalized.

"The authorities have completed a full poverty reduction strategy paper (PRSP), prepared on the basis of an extensive participatory process and providing a coherent framework for the government's poverty-reduction strategy. While implementation of the PRSP is set to begin in mid-2005, the government will be seeking donor financing for the PRSP activities in a Consultative Group meeting, now planned to take place in the fourth quarter of the year. Sierra Leone could reach the HIPC Initiative completion point by mid-2006, after one year of successful implementation of the full PRSP. The government has requested an advance of additional interim HIPC Initiative assistance to help smooth out obligations falling due to the Fund.

"It was recognized that an early move to a successor arrangement will help support the country's efforts to achieve the MDGs and reach the HIPC Initiative completion point, and help catalyze external assistance," Mr. Carstens said.

The PRGF is the IMF's concessional facility for low-income countries. PRGF-supported programs are based on country-owned poverty reduction strategies adopted in a participatory process involving civil society and development partners and articulated in a Poverty Reduction Strategy Paper. This is intended to ensure that PRGF-supported programs are consistent with a comprehensive framework for macroeconomic, structural and social policies to foster growth and reduce poverty. PRGF loans carry an annual interest rate of 0.5 percent and are repayable over 10 years with a $51 / 2$-year grace period on principal payments. 


\section{Statement by Peter Gakunu, Alternate Executive Director for Sierra Leone and Joseph Tekman Kanu, Advisor to Executive Director June 1, 2005}

On behalf of our Sierra Leonean authorities, we thank Management and staff for their continued involvement and support and for the extensive technical assistance provided to them. Sierra Leone's macroeconomic performance over the years has consistently improved, largely as a result of the authorities' commitment to ensure that program goals are achieved. Going forward, the authorities are keen on implementing policies aimed at promoting sustainable economic growth and improving the delivery of public services. In addition, several key developmental areas have been identified in the recently concluded PRSP, which are expected to guide the country's efforts towards achieving the Millenium Development Goals.

\section{Economic Developments in 2004}

Sierra Leone continues to make progress towards completing the post-conflict transition. The country successfully conducted local government elections in 2004. Broad based economic recovery continued in 2004 as reflected by the 7.5 percent GDP growth. Inflation increased to 15 percent in August 2004, reflecting exchange rate pass-through fueled by high oil prices, together with the effects of temporary supply constraints on domestic staple foods. However, following the authorities' decision to tighten monetary policy at the end of the year, inflation declined to 7.5 percent in early 2005 . Fiscal performance was stronger than programmed in 2004, while domestic revenue increased to 12.3 percent of GDP, thereby slightly exceeding program target. The overall fiscal deficit was well below the program level given the shortfall in externally financed development expenditures. The budget deficit was largely covered by donor financial assistance. In this regard, my authorities would like to record their appreciation for the continued support provided by the development partners, which has played a key role in assisting the country in its adjustment and reform process.

As a result of restrictive monetary stance, broad money growth, albeit higher than programmed, declined significantly compared to 2003 . The external current account deficit improved significantly in 2004. Export performance remained strong especially in the diamond sector while imports were lower than expected, despite higher fuel costs. Gross official reserves increased to the equivalent of 3.1 months of imports, thereby significantly exceeding program targets. The maintenance of a flexible exchange rate has contributed to maintain Sierra Leone's competitiveness.

The authorities have intensified efforts to keep the program on track, although, at endDecember 2004, the quantitative performance criteria on domestic primary deficit was missed by a negligible margin because of reasons beyond the authorities control. As regards the missed structural performance criterion, a full reconciliation of fiscal and monetary data for 2000-02 was not completed due to inherent technical difficulties and huge resource requirements. The authorities are taking action to implement the new data reporting framework recommended by STA in order to support broad based reconciliation. The 
authorities have requested waivers for the non-observance of these two performance criterion.

\section{Macroeconomic Framework for $\mathbf{2 0 0 5}$}

The macroeconomic framework for 2005 envisages continued robust output growth and low level of inflation. Mining, agriculture, manufacturing, and services will continue to drive growth which is projected to be about 7.5 percent in 2005. Average inflation, which is expected to decline significantly in response to tighter fiscal and monetary policies, is currently projected at 8.5 percent, partly as a result of higher fuel costs.

\section{a. Fiscal Policy}

The authorities' fiscal policy for 2005 aims at promoting macroeconomic stability and medium-term debt sustainability and is consistent with the medium-term fiscal strategy embedded in the PRSP. The domestic primary deficit, is expected to decline further which will allow the domestic financing of the budget to be contained below 1 percent of GDP. This will be supported by tying expenditure authorizations to 50 percent of external budgetary assistance. The approach will enable the authorities to meet adjusted ceilings on net bank credit, whenever there is an unexpected shortfall in external budgetary support.

The authorities will continue to enhance their efforts on revenue collection, which is projected to increase to 13 percent of GDP. However, measures are being taken to bring certain tax rates in line with those in neighboring countries, and the move to harmonise custom duties with the ECOWAS common external tariff (CET) will lower tax revenues. In order to offset these losses, the authorities intend to take specific budget measures to raise tax revenues, as well as, various other user fees. To this effect, the authorities are prepared to review the revenue outturns in mid-2005, and will introduce additional revenue measures as and when necessary. Expenditure trends on the other hand will reflect key development priorities as stated in the PRSP. In particular, measures will be implemented to contain the non-wage recurrent outlays so as to offset the higher wage-related expenditures and the cost of servicing the domestic debt. In so doing, poverty-related outlays and targets will be protected, and their levels raised to 5 percent of GDP subject to the availability of donor financing. Non-priority recurrent expenditures will be contained in case of non availability of budgeted revenue trends.

\section{b. Monetary and Financial Sector Policies}

To complement fiscal policy in reducing inflation, monetary policy will continue to remain tight. Reserve and broad money are projected to grow below that of nominal GDP growth. The Bank of Sierra Leone will also continue to conduct open market operations with a view to absorbing excess liquidity from the banking system. Because of the need to operationalize the liquidity-forecasting framework and electronic book-entry system, secondary market trading of treasury bills will commence early 2006. Private sector credit is expected to slow as a result of the increased reserve requirements. Also, in order to safeguard the soundness of the banking system, efforts will be made to reinforce bank supervision and to ensure that adequate provision is made against non-performing loans. Additional measures are being 
taken to implement the International Financial Reporting Standards. The authorities are also taking action to increase the paid-up share capital of the Bank of Sierra Leone, which they were not able to meet because of budgetary constraints. However, to address these issues, the authorities hope that their request for further technical assistance from the Fund could be favorably considered as soon as possible.

\section{c. External Sector Policies}

The current account deficit is projected to widen to 13 percent of GDP in 2005 because of the import of large capital items for the rehabilitation of mining operations, while mineral exports are expected to fall. Gross international reserves are projected to decline to 2.8 months of import cover largely as a result of a decline in external budgetary support.

The authorities view the reforms in the mining sector as important to attract private investment. To this effect, they intend to continue to implement measures to strengthen the regulatory environment in the mineral sector. In this regard, and with support from DfID, they will direct efforts towards strengthening the newly established law commission that will bring together the fragmented legal system governing the minerals sector. In addition, they will be introducing a mining cadastre, which is expected to lead to improvements in tracking mining activities. The authorities have expressed interest in participating in the Extractive Industries Transparency Initiative (EITI) and have requested technical assistance from DfID.

On external debt, 10 out of 11 Paris Club creditors have agreed to provide debt relief under Naples terms. They have also agreed to extend the consolidation period for debt relief until the current PRGF arrangement expires. For commercial creditors, the authorities will continue to be engaged in efforts to reach collaborative agreements on the settlement of arrears, that include making goodwill payments to creditors operating in the country. The authorities are grateful to the World Bank for favorably considering their request to access the debt reduction facility.

\section{d. Structural Reforms}

In an effort to meet program objectives, the authorities are in the process of revamping the fiscal and monetary reporting system with technical assistance from the Fund. The envisaged structural reform framework, which will be implemented in early 2006, will help to facilitate thorough reconciliation of both fiscal and monetary data. The authorities remain confident that the Fund will be able to respond positively to their requirements for additional technical assistance which will enable them to advance the medium-term budgetary framework for the mineral sector.

\section{The PRSP Process}

To buttress their commitment to program implementation to allow Sierra Leone to reach the completion point, the authorities finalized the full PRSP in early February 2005. The overall objectives of the PRSP are to substantially reduce poverty, hunger and unemployment; adhere to each and every one of the MDGs; ensure lasting security and improve governance. This is an appropriate framework that tends to support the authorities' efforts towards 
poverty reduction. The authorities are aware that the attainment of the above objectives require sustained macroeconomic stability. In this regard, they are taking additional measures to align the budget with the PRSP, clarify expenditure priorities while taking into account the existing fiscal constraints, and will ensure provision of adequate capacity for effective monitoring and implementation. They will continue to strengthen domestic revenue collection, and would continue to seek external donor support, which will help them to protect priority programs and projects from adverse shocks. To achieve this, the authorities, in association with the World Bank and other donors, will be convening a consultative group meeting in Paris, where they look forward to muster the needed financial support that would enable them to continue to carry out their reform agenda and make progress towards achieving the MDGs. In order to strengthen the strategy and reduce implementation risks, the authorities are directing their efforts to addressing the key issues relating to the attainment of their PRSP objectives.

\section{Data Issues}

The authorities are committed to further improve the country's macroeconomic database. Sierra Leone has benefited from Fund TA in other areas including the targeted improvements in the coverage and quality of fiscal and monetary data and the compilation of BOP statistics in the context of the GDDS. Given this development, Sierra Leone's PRSP serves as an innovative approach for incorporating elements of the GDDS. This effort comprises a systematic diagnosis of the statistical system along with the formulation of a capacity building plan for statistical development. The GDDS plan for improvement has been integrated with the other statistical requirements of the PRSP, which have been costed and will be reflected in the annual budgets. This is expected to help identify the funding requirements for GDDS and PRSP statistical reforms. We are of the view that the benefits to be derived from this initiative will enable other countries to adopt the process.

\section{Ex-Post Assessment (EPA)}

The authorities are in agreement with the conclusions of the EPA relating to their engagement with the Fund since 1994. They also agree that the design of Fund-supported programs has been appropriate and, as such, appreciate the level of Fund involvement in the country, taking into account the underlying balance of payments need and external risks. In addition, they acknowledge that Fund involvement has played a major role in helping to stabilize the economy, providing a framework for policy implementation, developing capacity through provision of technical assistance and catalyzing donor support. However, the authorities are of the view that donor coordination remains weak, thereby introducing unpredictability in budgetary planning and occasionally stifling priority social expenditures.

The authorities are keen on moving to a Fund-supported successor program, which is considered relevant on account of the current substantial financing gap that need to be closed to enable them to make substantial progress towards meeting the MDGs. The authorities support the EPA recommendations for the Fund to remain closely involved in the provision of technical assistance in order to strengthen capacity in the areas of economic statistics and governance. For this to be achieved, effective donor coordination is vital in strengthening the effectiveness of technical assistance and macroeconomic management. 


\section{Conclusion}

To facilitate successful program implementation, the authorities have taken appropriate measures to ensure achievement of program objectives. They have contained fiscal expenditures and also mobilized budgetary support with the aim of promoting macroeconomic stability and debt sustainability. All prior actions have been implemented. The authorities have continued to pursue good faith efforts in negotiations with commercial creditors. In light of their satisfactory performance so far, they are requesting completion of the final review under the current PRGF program and an advance of additional interim HIPC assistance under the Enhanced HIPC Initiative for the period up to December 2005.

Going forward, and in accordance with the recommendations of the EPA, the authorities look forward to the Fund agreeing to a follow-up PRGF arrangement for Sierra Leone, which will allow them to pursue the remaining reform agenda.

Finally, we would like to inform the Board that the authorities have consented to the publication of the staff report and other related documents, as they firmly believe in the principle of transparency. 